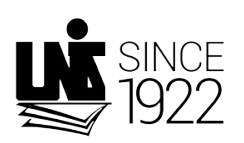

VOL. 89 • NO. 2 • NOVEMBER 2016
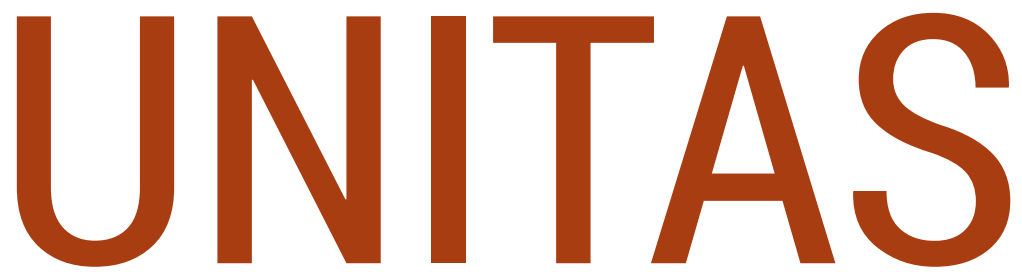

SEMI-ANNUAL PEER-REVIEWED INTERNATIONAL ONLINE JOURNAL OF ADVANCED RESEARCH IN LITERATURE, CULTURE, AND SOCIETY

\title{
Expressions of Tagalog Imaginary
}

The Tagalog Sarswela and Kundiman in Early Films in the Philippines (1939-1959) 



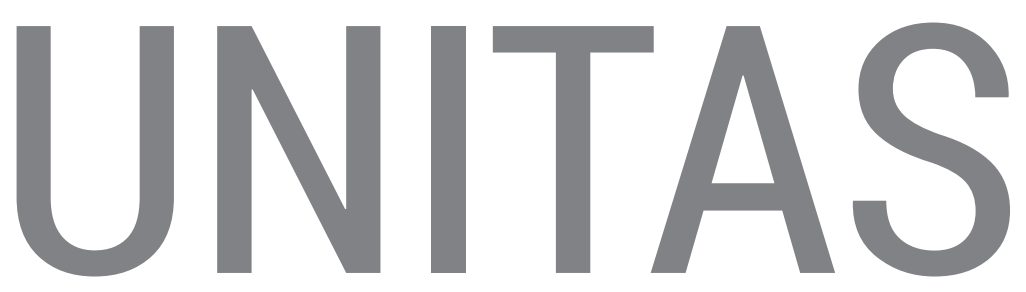

\section{Expressions of Tagalog Imaginary \\ The Tagalog Sarswela and Kundiman in Early Films in the Philippines (1939-1959)}




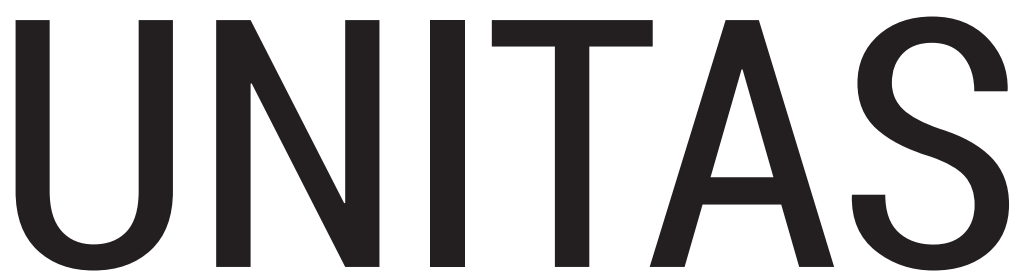

SEMI-ANNUAL PEER-REVIEWED INTERNATIONAL ONLINE JOURNAL OF ADVANCED RESEARCH IN LITERATURE, CULTURE, AND SOCIETY

\section{Expressions of Tagalog Imaginary \\ The Tagalog Sarswela and Kundiman in Early Films in the Philippines (1939-1959)}

\section{ANTONIO P. AFRICA}
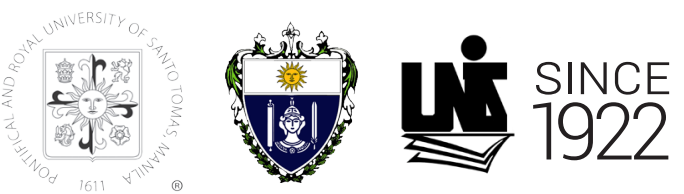
Expressions of Tagalog Imgaginary: The Tagalog Sarswela and Kundiman in Early Films in the Philippines (1939-1959)

Copyright @ 2016 Antonio P. Africa \& the University of Santo Tomas

Photos used in this study were reprinted by permission of Mr. Simon Santos.

About the book cover: Cover photo shows the character, Mercedes, played by Rebecca Gonzalez in the 1950 LVN Pictures Production, Mutya ng Pasig, directed by Richard Abelardo. The title of the film was from the title of the famous kundiman composed by the director's brother, Nicanor Abelardo.

Acknowledgement to Simon Santos and Mike de Leon for granting the author permission to use the cover photo; to Simon Santos for permission to use photos inside pages of this study. 


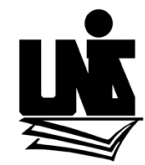

UNITAS is an international online peer-reviewed open-access journal of advanced research in literature, culture, and society published bi-annually (May and November).

UNITAS is published by the University of Santo Tomas, Manila, Philippines, the oldest university in Asia. It is hosted by the Department of Literature, with its editorial address at the Office of the Scholar-in-Residence under the auspices of the Faculty of Arts and Letters. Hard copies are printed on demand or in a limited edition.

Copyright @ University of Santo Tomas

\section{Copyright}

The authors keep the copyright of their work in the interest of advancing knowledge but if it is reprinted, they are expected to acknowledge its initial publication in UNITAS. Although downloading and printing of the articles are allowed, users are urged to contact UNITAS if reproduction is intended for non-individual and non-commercial purposes. Reproduction of copies for fair use, i.e., for instruction in schools, colleges and universities, is allowed as long as only the exact number of copies needed for class use is reproduced.

\section{History and Coverage}

Established in July 1922, UNITAS is one of the oldest extant academic journals published by a university in the Philippines as well as in Asia. Still, UNITAS is perhaps the oldest extant academic journal of its kind in the Philippines and Asia in terms of expansive disciplinary coverage and diverse linguistic representation through the decades. While always cognizant of disciplinary specialization, it has been "multidisciplinary" in publishing scholarship that is intra-disciplinary within the humanities and the arts, and interdisciplinary across the other disciplines. As it was in the beginning, it has aimed for "unitas" by conjoining disciplinary difference through its pages.

Moreover, it has been multi-linguistic on the whole, allowing itself to evolve from a journal published purely in Spanish, and then in English, becoming bilingual eventually in the various issues in which articles are written in Spanish and English, or 
as has been the case in the last several decades, in English and Filipino. And, of late, UNITAS has also published articles in other languages.

Apart from its disciplinary inclusiveness and crossovers, in almost 100 years of its existence, UNITAS has expanded the conceptual terrain of academic and topical coverage. It has published on cutting-edge and time-honored themes in which both established and emerging voices in research and scholarship are heard in articles that range across traditions, modernities, movements, philosophies, themes, politics, geographies, histories, musical types, architectural styles, gender relations, sexualities, government and non-government institutions, educational philosophies, media, forms, genres, canons, pedagogies, literary and cultural relations, and comparative studies, among others, in book review essays, critical commentaries, scholarly papers, and monographs. Such an expansiveness has allowed for establishing new lines of inquiry or exploring new lines of thinking about old ones.

\section{Editorial Policy}

UNITAS invites work of outstanding quality by scholars and researchers from a variety of disciplinary, intra-disciplinary, interdisciplinary and cross-disciplinary principles, protocols and perspectives for its readership consisting primarily of academics, researchers, and graduate students, as well as of a diverse public consisting of scholars and leaders who are at the forefront of their fields and advocacies, undertaking research on multidisciplinary aspects of national and global issues within and beyond academia broadly from the perspective of but not limited to the human sciences.

In general, UNITAS aims to publish leading-edge and challenging articles and monographs in regular and special issues in relation to the critical currents and themes of the nation, the Asian region and the world which try to meet the various problems and opportunities of today's globalization.

Although single-authorship of articles remains typical, UNITAS encourages the submission of papers that are co-written by authors working across multi-cultural and multi-linguistic settings, which have resulted from an inter-cultural, inter-regional or inter-national collaboration of researchers in an effort to internationalize knowledge production, circulation and reception.

In particular, under the rubric of literary and cultural studies in Asia, UNITAS aims to be a platform for ethically engaged studies that represent intersections of national and international literatures, arts and cultures, crisscrossing critical and creative categories, authors and readers, "East" and "West," "North" and" South," text and 
context, close readings and fieldwork, original works and translations, and theoretical and practical methodologies.

UNITAS welcomes submissions from all locations of the globe which are published in English, Philippine national and regional languages, and other foreign languages. Non-English language articles are required to submit an extended abstract in English containing the full argument rather than just a digest of the main idea.

Submissions to UNITAS are to follow the $8^{\text {th }}$ edition of the MLA Style Manual. During the evaluation process, unless otherwise recommended by the double-blind peer reviewers to use a different documentation format, articles must be published following the MLA guidelines.

\section{Ethical Policy}

Every submission is assumed to have not been previously published and is not under consideration elsewhere for possible publication, unless it is a major submission meant as a reprint, and later approved for publication as such.

Plagiarism is the copying of large blocks of texts of someone's work and representing them as one's own. If plagiarism is ascertained after publication, the article may be withdrawn or retracted. Self-plagiarism or or duplication of passages without proper citation will be evaluated on a case-to-case basis.

After the protocols of peer review and editing, UNITAS may or may not ask the authors to review the article prior to publication due to constraints.

Securing the publishing rights of all photos, images, or charts accompanying the article is the responsibility of the author.

Articles have to be submitted via e-mail to unitasust@gmail.com

Address all communications to:

University of Santo Tomas Office of the Scholar-in-Residence/UNITAS Office, Faculty of Arts and Letters

G/F, St. Raymund de Peñafort Building, España St., 1008, Manila, Philippines Telephone No: 406-1611 loc. 8830

Layout by Paolo Miguel G. Tiausas

UNITAS Logo by Francisco T. Reyes 


\section{International Editorial Board}

Patricio Abinales

University of Hawaii at Manoa, US

Syed Farid Alatas

National University of Singapore

Jonathan Beller

Pratt Institute, US

Melani Budianta

University of Indonesia

\section{Richard Chu}

University of Massachusetts, US

Fabian Antonio M. Dayrit

Ateneo de Manila University

Joel David

Inha University, South Korea

Eduardo Deves-Valdes

Universidad Santiago de Chile

Leonard Harris

Purdue University, US
Caroline Sy Hau

Kyoto University, Japan

\section{Loren Kruger}

University of Chicago, US

Bienvenido Lumbera

University of the Philippines

Pawit Mahasarinand

Director, Bangkok Art and Culture

(BACC)

Victor Merriman Edge

Hill University, UK

Patrick A. Messerlin

Sciences Po, France

Resil Mojares

University of San Carlos

Cebu City, Philippines

\section{Mitsuya Mori}

Seijo University, Japan 


\section{International Editorial Board}

Tran Van Phuoc

Hue University, Vietnam

San Juan, Jr.

University of the Philippines

Stephen Shapiro

University of Warwick, UK

Inseop Shin

Konkuk University, South Korea

Brian Singleton

Trinity College Dublin, Ireland

Megan Thomas

University of California, US

Nicanor G. Tiongson

University of the Philippines

Lily Rose Tope

University of the Philippines

\section{Ruanni Tupas}

National Institute of Education,

Singapore

\section{Christa Wirth}

Universität Zürich, Switzerland

\section{Paul Young}

University of Exeter, UK

\section{Nie Zhenzhao}

Zhejiang University, China 


\section{Editorial Staff}

Maria Luisa Torres Reyes

maria.luisa.reyes@ust.edu.ph

EDITOR IN CHIEF

Joyce L. Arriola

ASSOCIATE EDITOR

Maria Eloisa S. Perez

ASSISTANT EDITOR

Nicole R. Tablizo

MANAGING EDITOR

Jan Raen Carlo M. Ledesma

EDITORIAL ASSISTANT 


\section{Contents}

xii In This Issue

xiii Acknowledgements

xiv Abstract

$1 \quad$ Preface

9 The Marriage of Tagalog Music, Theater, and Film

17 The Staged Sarswela and the Sarswela Film

26 The Language of Kundiman in Films: Awa at Pag-asa

43 Filipino Films in Focus: Synopsis and Musical Analysis

75 Summary

79 Glossary

81 Appendix

145 Works Cited

152 About the Author 


\section{In This Issue}

Expressions of Tagalog Imaginary: The Tagalog Sarswela and Kundiman in Early Films in the Philippines (1939-1959) by Antonio P. Africa is part of a series of issues lined up by UNITAS on Filipino music, authored by noted musicians AND scholars of Philippine music-a rare breed of double proficiency in a country like ours where music is often viewed less as a disciplinary field of research than as a vocation for practitioners and performers.

Through the study of Filipino music, particularly, of the kundiman and the sarswela, Africa's monograph studies the embodiment of the "ethnie" in the Tagalog imaginary in the early 20th century as the Tagalogs, along with the country's other cultural groups, struggled through centuries of colonization toward Filipino nationhood in the midst of westernization.

Drawing from the culturalist thread of Anthony Smith's work without fully adopting his historicist standpoint in his study of European nationalism, Africa analyzes the integrative Tagalog ethnie in his survey of selected Tagalog films, as it connects with familiar cultural ethos of the early eras in which traditional values are opposed to "western" ones. In this opposition, one imagines, these Tagalog films which were eventually shown beyond the Tagalog region, must have become a mechanism of diffusion of traditional values of the Tagalog ethnie referencing national identity through the colonial years. In fact, as the study asserts, "this ethnie imaginary lived through the decades and conveyed itself in Tagalog films during the Second Golden Age of Philippine Cinema up to this date, a testament of the people's reaction to its experience through music and film."

In the analysis of the Tagalog films, behind the labas of the musical performances (the palabas, if you will) was the loob's ethos of awa at pag-asa which propelled the nationalist spirit throughout the colonial periods and post-colonial years. As the book states, "The kundiman and sarswela complement each other through loob whereby a significant connection is created."

In this sense, between the notion of loob and labas was the Tagalog ethnie, making it possible to imagine the Tagalog society as a collective cultural unity through the kundiman and sarswela, cultural genres which became "instruments of the inner self, the community, God and man, culture and traditions, and nationhood, creating an imaginary expressive of the Tagalog movie-going public."

In such ethos, the loob is in reciprocal if contradictory relationship with the labas out of which dynamics the Filipino ethnic traditions and national identity are reconstructed if not invented allegorically in the spirit of what is now understood as modern nationalism.

As such, as may be gleaned from this study, the musical is, indeed, political, enabiling the readers to enter one side in order to come out the other side: the Tagalog imaginary. 


\section{Acknowledgements}

My deep gratitude goes to the following people who in one way or another contributed to this monograph:

Mr. Simon Santos, the owner of Video 48 shop and Filipino classic film collector, for being very accommodating in providing DVD copies, electronic copies of flyers, photos, and other literature materials that facilitated the completion of this study.

Maestra Irma Ponce-Enrile Potenciano, Mr. Nick de Ocampo, Dr. Michael Coroza, Mr. German Moreno, and Mr. George Torralba for the interviews on Philippine film.

My music colleague Mr. Allan Pastrana for the final editing and my good friend Prof. Augusto Antonio Aguila for preliminary edits.

My colleagues and friends at the University of Santo Tomas and its Conservatory of Music: the Rector Magnificus-President, Rev. Fr. Herminio Dagohoy, O.P.; Vice Rector Rev. Fr. Richard Ang, O.P.; Secretary General, Rev. Fr. Winston Cabading, O.P.; Vice Rector for Academic Affairs, Prof. Clarita Carillo, Ph.D.; University Registrar, Mr. Cesar Velasco; Conservatory Regent, Rev. Fr. Jose Tinoko, O.P.; Dean Raul Sunico, Ph.D.; A/Prof. Cynthia Afable, A/Prof. Peter Porticos, A/Prof, Naomi Sison, and Mr. Antonio Ruben Gutierrez.

My house assistants in Lipa who took good care of me during my long stay: Mariano Mendoza and Charwin John Dagohoy.

My mother Susana Paterno Africa, my brothers Rt. Rev. Fr. Eduardo Africa, O.S.B., Tomas, Carlos, my sisters Marilda and Alma Maria.

My former classmates in the $\mathrm{PhD}$ program who have always been very supportive. Thank you very much! 


\section{Abstract}

The aural and the visual aspects of Tagalog films create impressions of local culture, values, and tradition. They are expressions of a community, aptly embodying its lifeways and environment, displaying the changes through centuries and decades of colonial rule, showing the value they give to culture through music and film.

The relationship between Tagalog films and the kundiman brings to fore an interconnection that defines a sensibility common to Tagalogs: that hope springs eternal which, in this paper, refers to awa at pag-asa, a phrase which I conceived drawing a parallel to the Filipino philosophy loob. Loob is the Filipino separated from his inner-being because of the invasion of colonizers and the Filipino who seemed to have sulked within himself. Loob is timeless, not individual, not historic yet it connects to time and space which is labas; the spirit of the Filipino traversing his story (Salazar).

Labas was expressed through the sarswela which, in the early twentieth century, became the instrument of expression of what was transpiring in Philippine society. The audience saw themselves onstage as actors who weaved through the story and music, describing the socio-political situation. Bucolic setting amidst the changing scenario brought about by the American occupation generated strong expressions of nationalism. City scenes (lungsod), costumes of the American coat and tie, ragtime- and foxtrot-inspired music, and the effects of colonization epitomized progress and corruption. The countryside (nayon), native costumes, and folk melodies projected the time-honored traditions of the locals. The sarswela was the environment where one saw the Filipino loob as he suffered and hoped that redemption would eventually take place.

The kundiman is found within a sarswela; therein, the loob and labas become a representation of a Tagalog with his life, hardships, challenges, aspirations, and hope. An ethnie takes shape. It is a collective cultural identity that emphasizes the role of myths, of descent, and historical memories distinguished from the national perspective (Smith) through the kundiman 
and the musical theater, sarswela.

This ethnie imaginary lived through the decades and conveyed itself in Tagalog films during the Second Golden Age of Philippine Cinema up to this date, a testament of the people's response to their experience through music and film.

\section{Keywords}

Second Golden Age of Philippine Cinema, Tagalog films, Sarswela film, Film sarswela, sarswela, kundiman, loob, ethnie 



\section{Preface}

Music and film express the culture and traditions of a people. These manifest the changing time and milieu while taking into account concepts that underscore the production of an imaginary. The aural and visual features of early Tagalog film musicals are articulations of history and an imagination that stems from the kundiman and the music of the sarswela.

The Spanish zarsuela, brought in by Dario Cespedes, aimed to "acclimatize the Filipino to Spanish values and norms" (Lapeña-Bonifacio 54). As the zarsuela evolved into a local music theater form through the training of local artists and production of new materials by Filipino playwrights and composers, the zarzuela was indigenized and appropriated into a local music theater, the sarswela. The period under consideration was the last decades of Spanish rule and the beginnings of the American occupation, an era of change and hope for Filipinos seeking freedom from foreign dominion.

Tagalog playwrights took their pens and expressed their sentiments; composers wrote music in which were inscribed metaphors through the kundiman and presented it to the audience who shared the same aspirations 
and attributes. It was the attachment to and association with the aspirations of freedom from servitude that created this ethnie imaginary.

Ethnie refers to a type of cultural collectivity that emphasizes the role of myths, descent, and historical memories which are recognized through one or more cultural specificities like religion, customs, language or institutions, firmly held and enunciated by just a small segment of a designated population, with some attributes more intense and salient only at a particular period (Smith 21). The sense of continuity of this ethnie from the staged sarswelas to films through the works of playwrights and composers steadily evoked powerful images of identity with which future generations continue to identify themselves.

The films covered in the study express meanings that point to topics of love, be it evocative of personal affection or love. Most of these films are classified as musical films in which the concepts of awa at pag-asa and lungsod at nayon appear clearly.

Filipino music from the last decade of the Spanish regime to the first half of the 20th century made an impression on local culture beyond this period. The first decades of the twentieth century saw the flowering of the Tagalog sarswela which became a model for stories and plots of early Filipino film musicals. The kundiman, through its extra-musical meaning, awa at pag-asa, expressed the sufferings of a people willing to go through tribulations with the hope for redemption in the end.

This study aims to understand expressions of Tagalog imaginary by discussing the role of music as it manifests in selected film sarswela and kundiman melodramas from 1941 to 1959, and it becomes an expression of the people who go through transformation brought about by the colonizers.

It is a pioneering study that hopes to stir interest from the research community and eventually produce more literature on the role of music in Filipino films. The study also hopes to heighten awareness of the preservation of artifacts, specifically locally produced movies that have been neglected for decades, resulting in the dearth of extant Filipino classic films. There are other genres of non-musical films produced during this era but these will not be part of the study.

The collection of research materials started with the acquisition of digital copies of Filipino classic films. ${ }^{1}$ From the sixty films initially viewed, 
nine films from 1939 to 1959 were selected. ${ }^{2}$ Five interviews between 2014 and 2015 were conducted with key resource people, namely George Torralba, Nick de Ocampo, German Moreno, Irma Ponce Enrile-Potenciano, and Michael Coroza. In addition, available materials such as movie flyers and newspaper advertisements, covering the years 1919 to the present, were compiled. Out-of-print books on Philippine film and theater gave information on the early years of film production.

A scene-by-scene mapping for each film was done to identify the music and identify its function as diegetic or non-diegetic. Diegetic music refers to music that comes from a physical source within the story space which the characters are aware of (Stam et al. 62). On the other hand, non-diegetic is music outside of the narrative space, otherwise referred to as background music (Stam et al. 62). The musical films have music as part of the story space and barely used non-diegetic music, which is atypical by today's music scoring norms. For the other films which did not have diegetic music, the prevalent "background music" gave the film a resemblance of what a musical film is.

The dearth of extant copies of early Tagalog film musicals was a setback for the study. The different sources of information such as movie flyers, photos, clippings, and reference books provided an overview. The inclusion of the lyrics of $\operatorname{song}(\mathrm{s})$ on flyers indicates that the songs were among the selling points of a film. Newspaper clippings gave information whether a narrative is a musical or not through its promotional text, layout, and/or inclusion of the singer's name or an orchestra.

The musical scores and transcriptions were used in analyzing the music. The analysis is semiotic-based, which interprets meanings through musical texture, range, timbre, dissonance, and modality. Resultant signifiers of musical elements include mood (sad or happy), size, density, and texture of scene and/or character. Leitmotifs were identified. These are musical fragments associated with a character, scene, or object. Songs composed prior to the filming of a movie but bears its title was also identified as the role of song in a film and is examined in terms of how it affects a film's narrative content.

The scope of the study covers filmmaking in the Philippines: just before the outbreak of World War II from 1941 which is part of what is known as the first Golden Age of Philippine Cinema, and after the war from 1946 until 
1959 which is the period of the second Golden Age of Philippine Cinema. This period study of Tagalog films is an attestation of the importance and influence of music on the film as film companies have resident composers and maintain their own orchestras ${ }^{3}$ to provide music for films. This is the period when staged sarswela and kundiman-titled films were produced, ${ }^{4}$ pointing to the preferred genre of the viewing audience. The output also signifies the continuity of shared memories arising from early history through the music of the kundiman and sarswela that shaped the imaginary brought about by past experiences of the earlier generation.

There are around four hundred fifty (450) Filipino films produced from 1919 to the 1950 s but there are only about a hundred of these available today. ${ }^{5}$ The one hundred (100) films comprise mostly Tagalog film musicals as well as melodramas that, based on this study, bore the extra-musical tenor of the kundiman. The selected films covered in the study total nine (9) movies. Chronologically, these are: Tunay na Ina (1939), Pakiusap (1940), Sarung Banggi (1947), Mutya ng Pasig (1950), Maala-ala Mo Kaya (1954), Ang Tangi Kong Pag-ibig (1955), Anak Dalita (1956), Bituing Marikit (1957), and Kundiman ng Lahi (1959).

Source materials on Filipino film history, sarswela, and kundiman were thoroughly surveyed to help establish the field of knowledge the study aims to contribute to.

Historical information about Filipino films comes from Nick de Ocampo (2007 and 2011), Vicente Salumbides (1952) ${ }^{6}$, and Jesse B. Garcia $(2004)^{7}$. The history of film in the Philippines started with the arrival of the Cronofotografo, shipped-in by Señor Francisco Pertierra in December 1896. Short films lasting a few seconds were presented in batches but failed to sustain the interest of the local audience. A new programming which included musical excerpts from operas placed between films attracted the audience back, and this prompted the film house owners to organize their resident orchestras for the music aspect of the program. After a decade, the advent of new technology from the outside encouraged Filipinos to start producing films. Thus, by 1913, the first short film feature based on the sarswela Walang Sugat was produced. In 1919, Jose Nepomuceno's Malayan Films premiered the first Filipino full-length feature film, "Dalagang Bukid," with Atang dela Rama in the title role. Dela Rama, with three 
instrumentalists, also provided live music for the film by performing her songs behind the screen while the film was being shown. Jose Nepomuceno's entry as producer and director ushered the coming of more Filipino directors such as Carlos Vander Tolosa, Gerardo de Leon, Octavio Silos, Carlos Padilla, and the first Filipino female film director, Carmen Concha, all of whom in effect having started the "Filipinization" of the local film industry. The arrival of the sound-on-film technology in the early thirties led to the birth of the major film companies. Sampaguita Pictures presented its initial presentation, Bituing Marikit, in 1937. Likewise, Parlatone Hispano-Filipino produced Nasaan Ka Irog in the same year. Both films mentioned are musical in nature. In 1939, Giliw Ko, the first production of LVN Pictures, premiered at the Metropolitan Theater with no less than Commonwealth President Manuel L. Quezon in attendance. Film production was on the rise when the Second World War broke out and as a consequence, production of films halted except for four films produced and shown during the Japanese Occupation. After the United States-granted Philippine Independence in 1946, film production resumed leading to the "Second Golden Age of Philippine Cinema" (Torre 51). It was during this period that the kundiman melodrama was established along with the continued production of sarswela films.

Aside from the importation of film technology to the country, the arrival of the Spanish zarzuela and American comics became sources of stories for film. Literatures edited and written by Isagani R. Cruz ${ }^{8}$ and Amelia LapeñaBonifacio provide historical detail on the Tagalog sarswela. In 1878, the theater company of Dario Cespedes staged the Spanish zarzuela, "Jugar con Fuego," written by Ventura dela Vega and Maestro Francisco Asenjo Barbieri. The locals appreciated the zarzuela, and this resulted in the arrival of more theater companies from Spain in the years that followed. In 1890, the earliest Tagalog sarswela, "Budhing Nagpahamak" written by Maximino de los Reyes with music by Maestro Isidoro Roxas, was presented to the public. During the period of the Philippine-American War (1899-1902), the stories that sarswelas presented shifted to socio-political themes. Playwrights such as Severino Reyes were tagged as seditious writers and were even jailed for their impassioned stage presentations. The Tagalog sarswela eventually became a source of narrative material for film musicals without its 
anti-American undertones, reflecting the changing sentiments of the locals toward its colonizer.

Literature on the kundiman is based on the writings of Antonio Molina (1940), ${ }^{9}$ Antonio C. Hila (2004), ${ }^{10}$ Ramon P. Santos (2005), ${ }^{11}$ and Teresita Gimenez Maceda (1998). ${ }^{12}$ "Kundiman ng Himagsikan"13 traces the beginnings of kundiman to its folk and revolutionary background with "Jocelynang Baliwag." ${ }^{14}$ Although this song's original text was not about the revolution, it was eventually adopted as the hymn of the katipuneros. The lyrical melody and its text brought to the minds of katipuneros their daughters, wives, and siblings whom they left behind to fight for the nation's aspiration for freedom. During the first decades of the twentieth century, the kundiman texts written by respected playwrights expressed nationalism, love, suffering, and hope. The text and melody created an effective tone painting that symbolized Filipino sensitivity. According to Teresita Gimenez Maceda, the kundiman is a love song that speaks of unrequited love, and at the same time expresses nationalism and love for Inang Bayan. The text that speaks of romantic love serves as metaphor for love of motherland.

The process of introspection (loob) leads to a better understanding of the external (labas). The interaction of the loob at labas ushers a Filipino's search for his personhood that facilitates his desire to move forward. It is in coming to terms with the reality of the self that one is able to pursue with equanimity. Prospero Covar connects loob in metaphor with the human body and the earthen jar, both of which were formed from earth, following the biblical belief that man came from ash/earth. Thus, the body is likened to an earthen jar; it has its outside, inside, and depth, and all these aspects are controlled by the soul/spirit and conscience. Reynaldo Ileto, in his study of a resistance movement, discusses $l o o b$ as the pro-active core of a person with its physical surroundings, society, and universe. The state of a person's loob can be seen through the events transpiring within the community. Zeus Salazar introduces the concept of pantayong pananaw (our point of view) as a cultural discourse and an introspection of a group of persons, of the characteristics, knowledge, aspirations, culture, norms, and experience of their culture expressed through the use of a language. ${ }^{15}$ The concept of loob is associated with the extra-musical awa at pag-asa of the kundiman as most of the pleadings in a kundiman melodrama point to the inner self of a character. 
Likewise, it reflects the scenes of community life in a sarswela film as it exhibits the influence of a society on the pagpapakatao of the characters and the kalinangang bayan expressed by the narrative.

Analysis of music as extra-musical expressions was based on musical form, leitmotif, and semiotics. The methodological framework "analogy-association" applied in the PhD dissertation of Juan Chattah Roque, "Semiotics, Pragmatics, and Metaphor in Film Music Analysis," was used as a model for the analysis in this paper. This in turn suggests an approach to explain the underlying message of music through analogy to the visual component and association generated by music in a particular scene or film.

After acquiring and viewing seventy-eight Tagalog films produced from 1937 to 2012 and reading the literature mentioned in this chapter, I have opted for the twenty years starting from 1939 as the period that would be best studied. It covers the two Golden Ages of Philippine Cinema. It was the time when technological advancement saw the film as the new form of entertainment. It was historically a transition period when the people hoped for redemption, embraced progress, and at the same time struggled to keep traditions alive. The sound and color of the film's aural and visual during this epoch manifested the Tagalog psyche and way of life.

\section{Notes}

1. Simon Santos, a collector of classic Filipino films and paraphernalia, is quite known in film circles for his collection. He has a video shop on West Avenue, Quezon City and maintains a film blog "Video 48 " which is also a rich source of information for Filipino films from pre-war to the present.

2. Prior to this, I wrote a study on Giliw Ko for my master's thesis. Thus, I decided to start from what I had done in my thesis and cover the next twenty years of Filipino film musical and melodrama.

3. The information is based on the opening billboards [or credits] of the films under study.

4. Kundiman ng Puso (1935), Nasaan Ka Irog (1937), Madaling Araw (1937), Mahiwagang Binibini (1939), Walang Sugat (1939), Prinsesa ng Kumintang (1940), Magbalik Ka Hirang (1940), Ang Viuda Alegre (1941), among others. All films mentioned are non-extant. 
5. This is a conservative estimate based on collated data.

6. See Vicente Salumbides' Motion Pictures in the Philippines whichwas published in 1952.

7. Jessie B. Garcia, who also painstakingly gathered all the trivia information together, edited this book which was printed in Iloilo City.

8. See A Short History of Theater in the Philippines edited by Isagani R. Cruz.

9. The full text of Antonio Molina's Kundiman ng Himagsikan was published in Publications of the Institute of National Language.

10. See Antonio C. Hila's Music in History, History in Music published in 2004.

11. See Ramon P. Santos' Tunugan: Four Essays on Filipino Music published in 2005.

12. See Teresita Maceda Gimenez' "Imaging the Nation as Inang Bayan: Kundiman and Other Songs on the 1896 Revolution" in the Filipiniana Reader.

13. The full text of Antonio Molina's "Kundiman ng Himagsikan” was published in Publications of the Institute of National Language.

14. The song form at this time was still folk in nature. The transformation of the kundiman as an art song was the result of the formal musical training of its prominent composers Bonifacio Abdon, Nicanor Abelardo, and Francisco Santiago.

15. Discussions on the Filipino concept of loob are based on the works of Albert Alejo, S.J. (1990), Prospero Covar (1993), Reynaldo Ileto (1979), and Zeus Salazar (2000). In general, the process of introspection (loob) leads to a better understanding of the external (labas). 


\section{The Marriage of Tagalog Music, Theater, and Film}

Film and music have always been interconnected, as film histories worldwide would indicate. When the films in this study were produced and shown, American colonizers had already brought in their culture and technology which explains the likeness of the two film industries. It is to be noted that the first American sound-film was a musical, The Jazz Singer (1927), just as a sarswela, Walang Sugat was the first silent film shown in Escolta (de Ocampo Cine 37). This chapter discusses the beginnings of film, specifically in Manila, and the ups and downs of this new entertainment form before flourishing into a full industry leading to its golden ages. But the local environment and space make the film narrative distinct, not just a process of integrating an art or entertainment form in a unified variety; it depicted the history in aural and visual forms, and the ethnie of the Tagalog way of living and thinking.

Filipino film history dates back to the days when Jose Rizal was executed at Bagumbayan in 1896. What started as a short feature film lasting several seconds became a full industry with three "golden eras." ${ }^{1}$ The first "Golden Age of Philippine Cinema," which began in 1930, produced a good number of musical films modelled on the sarswela. Despite the infantile stage of sound 
technology in film, the limitation of sound did not hinder film producers from creating musical-based movies.

Film historian Nick de Ocampo credits the arrival of the first film apparatus, cronofotografo, to Señor Francisco Pertierra, a businessman who also owned a listening salon at No. 12 Interior Escolta, Manila (de Ocampo Cine 37). The cronofotografo ${ }^{2}$ arrived in December of 1896 and was put to use by the first days of January $1897 .{ }^{3}$ The exhibition of short moving pictures lasting a few seconds and compiled in programs consisting of around ten shorts was the starting point of what was to be the film culture in the Philippines. With the Philippine Revolution of 1896, the Spanish-American War of 1898, and the Philippine-American War of 1899 , film presentations came to a halt. It was in 1902 when regular screenings resumed (de Ocampo Cine 59). With the growing number of the viewing public, movie houses were established in Manila. But the screenings did not last long as the enthusiasm began to wane due to the lack of dimensionality in a silent moving picture. For an audience who was familiar with music theater like the komedya and the sarswela with its songs, dances, and cast production numbers, watching a less-than-aminute film feature even if grouped together was less appreciated. ${ }^{4}$

In 1903, a new kind of programming was introduced by mixing a program of film shorts screened alongside intermedios cantos or musical intermissions. This was a solution to rectify the problem of dwindling viewership. The need for music to accompany the silent films created an increasing need for musicians. The first music directors, among others, were Señor Francisco de Barbat who pioneered in providing musical accompaniment; Maestro Jose A. Estella, director de orquesta at Gran Cinematografo Filipino; Don Manuel Eaga, director de orquesta at Gran-Teatro Cinematografo Libertad, and Francisco Buencamino, director musical of the Sexteto de la Orquesta Rizal.

The first film sarswela, Walang Sugat, by Severino Reyes ${ }^{5}$ and Fulgencio Tolentino was produced in 1913. This first version of the famous sarswela was directed by Albert Yearsley featuring the actors and actresses of the Gran Compania dela Zarsuela Tagala, founded and directed by Reyes himself. The sarswela is said to have been shot during its performance on stage and was shown as a silent movie accompanied by live music, the practice during that time. By the second decade, cinema was an hour-long entertainment. Films from the United States were imported and shown locally while local 


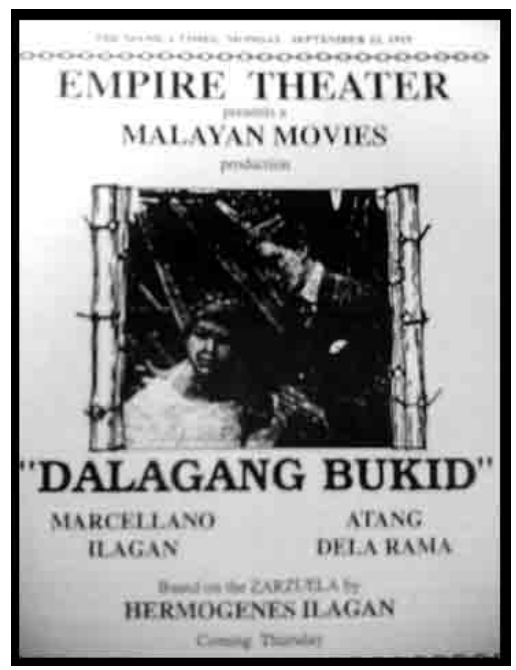

Fig. 1 Empire Theater's promotional poster of the Malayan Movies silent film production of "Dalagang Bukid" (1919). Reprinted by permission of Simon Santos.

companies such as the Oriental Moving Pictures Corporation of Albert Yearsley and the Rizalina Film Manufacturing Company of Dr. Edward Meyer Gross were established during the period. Jose Nepomuceno, the "Father of Filipino Movies," founded the Malayan Movies in 1917. Two years later, Nepomuceno produced and directed the first Filipino full-length silent film, "Dalagang Bukid," which starred Atang de la Rama who was also doing the stage version at the same time. He followed this up with "La Venganza de Don Silvestre" (1920), a sarswela sequel to "Dalagang Bukid," which he also directed and produced. These two films were silent-film sarswelas (de Ocampo).

There is little information with regard to the development of the local film industry in the next decade from the premiere date of "Dalagang Bukid." However, a change of direction back to the theater from film was noted, with a number of stage productions from 1920 to 1928. In 1930, Carlos Vander Tolosa directed Collegian Love, the first sound-on- $\operatorname{disc}^{6}$ film produced in the country. In 1932, Ang Aswang, the first sound-on-film directed by George Musser, was shown on January 1st at the Lyric Theater in Escolta. American 
film producers George Harris and Eddie Tait set up the Filippine Films in 1933 which introduced the studio-system ${ }^{7}$ that was adopted by leading film companies such as Sampaguita Pictures in 1937 and LVN Pictures in 1938. These two big film companies producing commercial films made extensive preparations for their initial offerings. Sampaguita Pictures' initial presentation was a sarswela film ${ }^{8}$ Bituing Marikit directed by Carlos Vander Tolosa, commissioning the Molina Symphony Orchestra for its music scoring and accompaniment and featuring as its lead star Elsa Oria, "The Singing Sweetheart of the Philippines." ${ }^{9}$ The inaugural presentation of LVN Pictures Inc. was Giliw Ko, also directed by Carlos Vander Tolosa, with Juan Silos Jr. and Ariston Avelino as its composers and musical directors. One of the five Tagalog pre-war extant films, Giliw Ko is a complete sarswela on film with an overture and nine songs half of which were done as production numbers. ${ }^{10}$

The choice of earlier film companies for their inaugural films was musicals as well. Parlatone-Hispano Filipino had Nasaan Ka Irog (1937, non-extant) directed by Carlos Vander Tolosa; Ang Maya directed by Jose Nepomuceno for Excelsior Films featured coloratura soprano Conzuelo Salazar; the sarswela Walang Sugat was the choice of Filippine Films (1939 non-extant); and Diwata Films' Mahiwagang Binibini, another film sarswela based on Ang Kiri (1939 non-extant), starred Atang dela Rama.

In 1941, the first year of World War II, accounts indicated that there was confiscation of equipment owned by the different movie companies. Some of the unfinished movies ${ }^{11}$ produced the previous year were shown to the general public to fill in the void. Films produced during the Japanese occupation included two films produced by LVN Pictures, namely Principe Teñoso, directed by Manuel Conde and released on October 03, 1942, and Tia Juana which was shown on May 27, 1943. Two other pictures, both produced by Toho Film Distributing Co. and directed by Gerardo de Leon, were Dawn of Freedom, released on March 08, 1944, and Tatlong Maria on October 12, 1944. During the war years and due to the moratorium on film production, film artists went back to the live stage for their daily subsistence (Moreno). Bryan L. Yeatter observed that "with all of the film studios closed down, the industry's workers had to find some means of subsistence, and so many of them took to working in the theater, a form of entertainment 
that the Japanese were quicker to allow" (37). The stage by this time played host to the new bodabil, a variety show that included songs, dances, acrobatic segments, and comedy skits. Irma Ponce-Enrile Potenciano mentioned that aside from the popular stage shows, opera productions not only abounded during World War II but that there were more of them at that time compared to the present. During the Japanese occupation, according to Potenciano, operas were popular across all economic classes and Tagalog drama plays were performed in theaters on Avenida Rizal.

After the war in 1945, cinemas in the Philippines re-opened, although it was well into 1946 before new movies were produced (Yeatter 46). Most films presented themes of gallantry among Filipinos in honor of the soldiers who fought for the country. The Tagalog film musicals also made its return to the big screen. Sarswela films were still popular, but changes in content began to be manifested. Traces of images and sounds of Hollywood musicals found their way into locally produced films. This marked the start of a new Filipino sub-genre labeled as the Hollywood-inspired musical. One of the post-war films included in this study, Sa Isang Sulyap Mo Tita (1953), undoubtedly adopted the Hollywood-style musical.

Revivals in the arts became prevalent in the film industry after World War II up to the late fifties. The culture of recycling materials from the past became a practice, re-visiting Filipino traditions and norms of pre-American Philippines. Non-musical Tagalog films revived epics such as Bernardo Carpio, a 1951 Sampaguita Pictures production. Musical films like Pista sa Nayon (1948), Mutya ng Pasig (1950), Maala-ala Mo Kaya (1954), and Kundiman $n g$ Lahi (1959) focused on Filipino life in the countryside. Revivals showed the changing taste of the Tagalog film audience. National Artist Virgilio Almario notes that the period was a reaction to Americanization, a period which he called balagtasismo, a nationalist movement that embodied the ideals of the Philippine revolution against Spain and continuously aimed to assert Philippine independence from American occupation (Almario). He describes balagtasismo as a cultural platform that "pre-occupies itself with the preservation of Filipino heritage encompassing old values, folklore customs, and traditions to strengthen the moral fiber of the people against the modern but corrupting American influences." Almario mentioned other symbols of Filipino nationhood such as the kundiman, barong Tagalog, and rural nostalgia 
(Almario). Thus, balagtasismo was not confined to politics, culture, and literature but might also be applicable to film and music. The period of revivals ${ }^{12}$ and the preservation of old values, folklore, and traditions complemented each other and were evident in the sarswela film and kundiman melodrama of the years leading to World War II and the fifties.

The fifteen films produced from 1939 to 1959 include four of the pre-war extant films, and those produced after Liberation starting in $1947 .{ }^{13}$ Giliw Ko, Tunay na Ina, Pakiusap, and Ibong Adarna are sarswela films. ${ }^{14}$ The interconnection of the selected films with music relates to several factors, including function and aesthetics of the movie. These factors include: 1) diegetic musical content of the film, 2) film taken from a staged sarswela, and 3) title of a kundiman or song. ${ }^{15}$

\section{Two Tagalog Genres: Sarswela Film and Kundiman Melodrama}

Let me point out that not all films produced during the period of 1939 to 1959 were musicals; other genres were produced as well. Aside from the prominence of sarswela-based films, the drama genre was quite popular and it is worth observing that a good number of these drama films were based on songs whose text and titles were used as story, plot, and titles of the film itself.

Following de Ocampo, there are two classifications for narratives based on the sarswela: the film sarswela, which is a successfully staged sarswela filmed in its entirety; and the sarswela film, which did not pass through the staged version but rather, is commissioned, mimicking the structure and aesthetics of a film sarswela (de Ocampo).

All musical films covered in the study fall under the sarswela film classification. To my knowledge, there are no extant film sarswela available to date. A primary consideration in classifying a sarswela film is the number of diegetic music featured in the narrative. The songs may number anywhere from four to eight, some of which are presented as "production numbers" featuring the cast or a number of performers/characters. These production scenes usually start and end the narrative.

Kundiman melodrama, ${ }^{16}$ on the other hand, is a drama narrative that establishes parallelism to the extra-musical meaning of a kundiman, awa at pag-asa. The song title is used as the film title. The kundiman on which the 
film is based is heard throughout the film diegetically and non-diegetically. Thus, a kundiman melodrama may not be a musical film but the prominence that is given to the kundiman used as on-scene performance (singing) and as background music gives an impression of the film being a musical. I would like to emphasize that aside from the music, the extra-musical meaning awa at pag-asa gives a kundiman melodrama its distinguishing character.

Between the two film styles, overlaps may occur, as the characteristics of one may be found in the other. A sarswela film may express the extra-musical awa at pag-asa concept found in the kundiman melodrama. Similarly, a kundiman melodrama may feature a song, dance, or a production number, similar to what is found in a sarswela film.

From the Spanish Zarsuela to the appropriated Tagalog sarswela, and its migration from stage to film, from the kundiman within and without the sarswela, expressing a soul-level perspective of the Tagalog experience to the film melodramas, we see differentiating elements of common culture and identity. It is the people finding themselves within the film and relating to the music who create a sense of belongingness. Powerful sentiments of nostalgia, history, and identification unify a people through film and music.

\section{Notes}

1. The CCP Encyclopedia of Philippine Art, Volume 8 mentions the three golden eras of Philippine cinema.

2. Cronofotografo is a Spanish term for a device that has the capacity to record motion through the use of successive still photographs. This device was invented by the Lumiere brothers. It paved the way for the invention of the cinematograph, the first celluloid-film motion picture camera projector.

3. De Ocampo based the information on an anuncio placed in El Comercio on January 02, 1897.

4. De Ocampo in Cine cites the lowering of ticket prices for the cinematografo exhibitions leading to its exit. Also cited was the reduction of screening hours.

5. Severino Reyes obtained a degree in Philosophy from UST.

6. Sound-on-disc refers to a kind of sound-film process which uses a phonograph to record and playback sound in sync with the picture shown. 
7. The studio system is the organizational setup of a film company with its own set of exclusive artists and production team.

8. Sarswela films did not have to pass through the staged version but were commissioned, mimicking the structure, aesthetics, and the melodrama of the film sarswela.

9. Unfortunately, this film is non-extant due to a fire that gutted the Sampaguita Pictures storage room (bodega) in 1950. To somehow restore its past, artists of Sampaguita, together with the producers decided to do remakes of their memorable films. Bituing Marikit being the inaugural film of the company was revived in 1957.

10. There is no set of rules that I know of that indicates the number of songs, dances, or musical productions in a musical play or film. As a theater music composer myself and together with a librettist, I would make personal decisions on the musical content and make sure there is enough for the film to be considered a musical. The number given is more or less the average in a musical film of this length.

11. These included Caballero by RDR Productions released March 01, 1942; Caviteno by LVN Pictures released March 12, 1942; Anong Ganda Mo directed by Gerardo de Leon, produced by RDR Productions, released May 09, 1942; Nina Bonita produced by LVN Pictures, released June 09, 1942; and Landas na Ginto produced by Sampaguita Pictures, released December 26, 1942.

12. Revivals here refer to the use of traditional literature or folk materials re-made into films.

13. There are actually five pre-war extant films but the earliest available one, Zamboanga, Fury in Paradise (1937), does not fall under the sarswela or kundiman kind thus I decided to exclude the film.

14. While Ibong Adarna is classified as a fantasy film and despite its classification under a different genre, it has a considerable number of diegetic music similar to sarswela films; thus I have decided to include it in my list.

15. In my interview with Nick de Ocampo, he stated that "song-titled" films may be classified under sarswela films.

16. This is a phrase that I coined to describe a Tagalog movie whose plot and characters show unrequited love, suffering, and sacrifice, a movie which culminates in hope and redemption. It parallels the extra-musical "awa at pag-asa" of the kundiman. 


\section{The Staged Sarswela and the Sarswela Film}

In this chapter, I will discuss briefly the beginnings of sarswela until its full bloom in the early twentieth century. Zarzuela's appropriation into sarswela shows how this musical theater form transformed into an ethnie imaginary as expressed by the playwrights through the plots, characters, and text of the libretto. Also, to be discussed is the change of the medium from stage to film in which the same Tagalog expressions are expressed.

The Tagalog sarswela is a form of theatrical entertainment that features music and dance woven into a play. When Dario Cespedes brought the Spanish zarzuela to the Philippines, its original aim was to "acclimatize Filipinos to Spanish values and norms" (Lapeña-Bonifacio 54). In the course of its production, local artists, playwrights, and composers took to the stage but new materials were also created. "Budhing Napahamak" is the earliest known sarswela written. Playwright Maximo de los Reyes and composer Isidoro Roxas wrote this sarswela circa 1890's. On June 14, 1902, Walang Sugat by Severino Reyes and Fulgencio Tolentino opened at the Zorilla Theater, its presentation onstage in 2010 shows its continuing popularity, its appeal to today's generation, and the endurance of its plot, story, and music. 
A Tagalog sarswela features grand opening and closing numbers. Opening numbers usually have the complete cast singing and dancing. The text of songs rendered in opening numbers ushers its audience into the narrative. Closing production numbers resolve conflicts in a manner happily accepted by everyone, complete with a big chorus and usually with the whole cast gathered in one happy song and dance spectacle. Atang dela Rama, the star of Dalagang Bukid, provides a look into the musical component of what constitutes a sarswela. She states that a sarswela contains twenty songs divided into preludio, concertante, solo, dueto, terceto and coro (Lapeña-Bonifacto 333). The songs function as the dialogue of the narrative or soliloquies of the characters, and the text of songs is written as part of the libretto. Rhythm, tempo, and musical form used for sarswela are based on folk and popular dances like danza, polka, foxtrot, marcha, pasadoble, valse, balitaw, and tango. Music is more prominent than the text unlike the kundiman's "text painting" where the sensitive and inherent union of text and music generates upon its listener-audience varied emotions ranging from melancholy and supplication to hope. Sarswela music is generally light, happy, and entertaining, which at several points of its plot may also be serious.

The characters in the sarswela are usually type-casted. Female leads or heroines are demure (mahinhin) reflective of the iconic "dalagang Filipina." The male lead is strong and brave, loving and sincere, loyal and chivalrous. Antagonist roles or contrabidas go against the grain of the ideal and traditional Tagalog mold. The servant role, called comico, and his partner (inamorata) provide comic relief as they go about their day-to-day chores (Lapeña-Bonifacto 332). Values shown in sarswela plots exemplify Tagalog conventions of ideal behavior. Here, women will not allow themselves to be touched; they are neither to be kissed nor embraced. Unspoken communication is done with a handkerchief, fan, a beckoning look, and manner of speaking (Lapeña-Bonifacto 335). Women cannot openly express their appreciation for a man and can only insinuate her feelings. The men epitomize chivalry in the tradition of the times. He patiently waits for his loved one and is ready for the call of his community to serve, protect, and fight if needed.

The turn of the twentieth century turned another chapter in Philippine history with the arrival of the Americans. 
Local leaders hoped that the Americans would free the nation from Spanish rule and recognize a government of, by, and for the Filipinos, but it turned out that the Americans would be the new colonizers. After the Philippine-American War (1899-1902), Tagalog playwrights began to create stories that served as commentary on the peculiarities happening in Filipino society. The sarswela served to discuss the social and political problems of the day while other forms sought to expose the mistakes and shortcomings of a government official or a well-known personage in the community (Cruz 144).

During the first decade of American rule, the sarswela espoused anti-American sentiments as an effect of the Philippine-American War. The war was considered "fierce and bloody," making the Spanish-American War pale in comparison (Francia 145). The American forces had a strong racist attitude against Filipinos, labeling them as "savages and barbarians" (Francia 146). The theater became a venue to express Tagalog sentiments over the turn of events. Tagalog plays transformed when it became apparent that there was no independence proclamation with the coming of the Americans. The shift in the nature of Tagalog theater happened despite the Sedition Law of 1901, which prohibited the public manifestations of nationalistic feelings and expressions of independence. Amelia Lapeña-Bonifacio cited that Tagalog plays changed hues and were tagged as chameleon plays (30). Walang Sugat exemplified this change, being anti-Spanish and anti-friar by nature and eventually, anti-American. A year after it opened, Walang Sugat continued to pack theaters to the curiosity of American officials who discovered that the "tall hatted figure of Uncle Sam" became part of the sarswela, had declared the Philippines his own, and demanded taxes from the locals. This was a period in the history of the local theater when Tagalog playwrights were considered "seditious," actually finding themselves donning a different role as Filipino propagandists. They were pursued by the law for "inciting the people of the Philippine Islands to open and armed resistance to the constituted authorities" and "inculcating a spirit of hatred and enmity against the American people and the Government of the United States in the Philippines" (Rafael 40).

In the following years, there were several Tagalog sarswelas that became popular and were presented outside of Manila. One of the best-known Tagalog sarswelas was Severino Reyes' one-act "Requiescat in Pace," which was presented in Teatro Zorilla on April 13, 1902 (Cruz 146). The play was an 
attack on the komedya, also called moro-moro. Other popular sarswelas were "Minda Mora" (1904) by Severino Reyes with music by Juan S. Hernandez, featuring Maria Carpena, the "Nightingale of the Sarswela;" "Filipinas Para los Filipinos" (1905) by Severino Reyes with music by Jose Estrella; "Paglipas ng Dilim" (1920) by Leon Ignacio; Ang Kiri (1926) by Servando delos Angeles with music by Leon Ignacio, produced as a film sarswela in 1939; and "Dalagang Bukid" (1919) by Hermogenes Ilagan and Leon Ignacio. "Dalagang Bukid" became the first Filipino full-feature silent film presented in 1919. The film was produced by Jose Nepomuceno, considered the "Father of Filipino films."

The sarswela mentioned above exhibited the change of narratives from cultural to politically-themed musicals and love stories with socio-political undertones, a reflection of the changing times, mirroring the condition of its Tagalog creators and viewers. This transformation bore the sentiments of a people yearning for change in the socio-political structure and hoping for a life where they are free to be themselves without fear of being misunderstood by the non-native rulers. The disjunct of the loob and labas generated by the circumstances of the Spanish Period was fuelled by the disappointment over the seeming take-over of the Americans when it was believed that the Americans came to liberate the nation from Spanish rule. This led to the nationalistic themes of "Walang Sugat," "Kahapon, Ngayon at Bukas," and "Filipinas Para Los Filipinos." ${ }^{2}$ The collective sentiments seen and expressed in the production of the Tagalog sarswela set the identity and imaginary of the Tagalogs.

In all the expressions of nationalism in the mentioned sarswela, lofty and soulful statements were to be found in the kundiman, a song distinct for its flowing melody, expressions of high ideals that transcend the mundane to a level of being spiritual. Just as the sarswela, as a whole, shows the big picture, the kundiman goes deeper into the Tagalog person, beyond time and space. The kundiman expression is timeless, and is a chronicler of the people's sentiments throughout the periods of history.

\section{Film Sarswela and Sarswela Film}

The decline of the staged sarswela may have been brought about by the new entertainment medium: film. The first decade of the twentieth century saw the rise of film screenings in Manila. These silent films were shown with live 
music, a practice during those times in other parts of the world. Intermission numbers consisting of live performances by artists from theater companies were added to film screenings to attract the local audience. Film exhibition houses such as Cinematografo Ideal and the Majestic Theater were opened in 1908 and 1910 respectively, ushering in a new entertainment form to which the sarswela would eventually migrate.

Film musicals were the popular genres based on the data gathered of films produced during the first decade up to the first Golden Age of Philippine Cinema, and beyond.

There are two historically-determined ${ }^{3}$ musical sub-genres in Tagalog films. The first is the film sarswela, which is a successfully staged sarswela filmed in its entirety; the second is the sarswela film, which does not pass through the staged version but is rather commissioned, mimicking the structure, aesthetics, and characteristics of a film sarswela (de Ocampo). Film sarswela abounded before the talkies (see Appendix for the timeline). Based on print materials such as flyers, posters, and local magazines (e.g. Literary Song-Movie Magazine), as well as on the Internet Movie Database (IMDb), six (6) films belong to this category, all of which are non-extant:

1. Walang Sugat by Severino Reyes. Directed by Albert Yearsley, 1913;

2. "Dalagang Bukid" by Hermogenes Ilagan and Leon Ignacio. Produced and directed by Jose Nepomuceno, 1919;

3. "La Venganza de Don Silvestre." Produced and directed by Jose Nepomuceno, 1920;

4. "Minda Mora" by Severino Reyes. Directed by Enrique HerreraDavila, 1929;

5. "Mahiwagang Binibini: Ang Kiri." Directed by Servando delos Angeles, Excelsior Films, 1939; and

6. Walang Sugat by Severino Reyes. Directed by Enrique Herrera Davila, Philippine Films, 1939.

A number of sarswela films are extant as discussed in this study. ${ }^{4}$

Both film sarswela and sarswela film bear the characteristics of a film narrative consisting of events arranged and designed to come to an ending through a series of events, conflicts, and revelations (Lumbera et al. 72). 
The technical aspects of film direction and cinematography merely put together the scenes rather than interpret characters and situations. Editing employs a relaxed pace reminiscent of komedy $a^{5}$ staging that leisurely proceeds in time. Though similar in its technical aspects, film sarswela diverges from the staged version in content.

Change in sarswela narratives from the "mother" Spanish zarzuela that introduced Filipinos to Spanish culture to the turn-of-the-century nationalistic-themed sarswela reflected the imaginary of the times. Sarswela films, which were produced during the Philippine Commonwealth (1935-1945), expressed an entirely new perspective towards American influence. Its distinct narrative did not include any anti-colonial scenes that may express anger or annoyance with either the Spanish or American colonizers. By the time the sarswela migrated to sound film in the thirties, it featured love stories set in progressive Manila and the rustic countryside, exhibiting the cultural differences between a Manila that was highly influenced by the American occupation and the rural areas which held on to the traditions and norms of "pre-American" Philippines. This contrast is interpreted as "lungsod at nayon" (Coroza), a phrase used as a metaphor to depict the corruption brought about by cultural appropriation seen in Manila and the time-honored Filipino traditions which are found in the provinces.

The pre-war Tagalog sarswela film, Tunay na Ina, appropriated American culture in some of its scenes. Contrasts of pastoral scenes provided a refreshing variation to what was traditional, vis-a-vis the appropriation of American ways and culture. The film was produced during the period of the Commonwealth and already presented Filipinos' friendly attitude toward the Americans compared to the early years of the Occupation. Lungsod at nayon was also evident in the style of music used in scenes providing a clear contrast aurally and visually.

Tunay Na Ina manifests expressions of the Tagalog imaginary at its most basic aural and visual levels. Tita sings a Tagalog folk tune with repetitive melodic pattern for a community celebration on Christmas Eve. In the final scene of the movie, she renders a Shirley Temple-styled, Tagalog Christmas tune in the house of her true parents. ${ }^{6}$

The inclusion of brass bands, which prominently perform in Tagalog cultural events, is obviously an important part of the narratives. Examples 
of these are the fiesta scene at the end of Mutya ng Pasig and in the scene of Pakiusap, when Amparing is escorted from her house to the wedding venue. The rondalla or string ensemble is likewise a favorite ensemble choice for sarswela films, as presented in Kundiman $n g$ Lahi in its opening scene; in Mutya ng Pasig, and in the wedding fluvial parade of Pakiusap. Both the brass band and the rondalla remind the viewer of Tagalog local traditions which represent the nayon.

Most sarswela films have a Christmas scene set in the narrative's denouement,_which also serves as another metaphor for nayon. Among the Tagalogs, Christmas symbolizes the communal character of celebrations shared amongst the members of the community describing the Filipino bayanihan spirit, emulating the nayon. In Tunay na Ina, it was at a community Christmas gathering that Magdalena was able to talk for the first time to Tita, her long-lost biological daughter. It was also at Christmas time when Tita went back to her biological family together with her step-mother, Aling Anday. In Pakiusap, it was Christmas when Amparing was about to marry Don Andres but was "saved" by Ernesto, her true love. Chedeng was proclaimed as Mutya ng Pasig then twenty years later, it was also at Christmastide when her daughter Consuelo was proclaimed Mutya ng Pasig. In Sarung Banggi, it was because of his participation as a singer in the Christmas Eve Mass that Nanding was able to go back to the nayon, marking not only his return to and re-acceptance by the community, but his engagement to Marina as well.

At a macro-level, the lungsod at nayon, or the city-countryside dyad, was evident in all sarswela films covered in the study. ${ }^{7}$ Covar's metaphor of katawan at banga $a^{8}$ (human body and earthen jar) largely applies the influence of society on an individual who creates his/her person but may change due to a new environment. Thus, a person who lives in the city would practice the life of a city dweller with its effects, and vice-versa. The change of environment from the Spanish to American Occupation resistance to the Philippine Commonwealth when the Tagalogs became receptive to American culture influences reveals a change in outlook and identity: the willingness to espouse change and progress with efforts to keep traditional Filipino values breathing within their persons.

Tagalog films after the devastation brought about by World War II expressed strong lungsod at nayon images in its narrative. Lungsod represented 
progress, money, and fame which a film character aspires for. In contrast, a character would opt to "go back to the nayon" to uphold the importance of family, values, and traditions that allude to contentment and happiness. The viewer will feel the hardship and hopes of a better life in Anak Dalita (1956) and Kundiman Ng Lahi (1959), both films produced a decade after the war. These two films describing lungsod at nayon through its stories and plot also lead us to the concept of the kundiman's extra-musical meaning, "awa at pag-asa," which illustrates the person's internal struggle as he/she copes with the changes brought about by external factors.

These films express the hardships of rebuilding a war-torn nation, striving to achieve independence in all levels of life and society. A strong sense of solidarity of a people is shown through a Tagalog film musical genre that originated from the staged sarswela. The continuity of aspirations of freedom and hope for the happiness of successive generations that share common experiences and history creates the Tagalog ethnie.

\section{Notes}

1. Aurelio Tolentino's sarswela attacks the American imperialists.

2. It is a sarswela-satire on a law penned by the Congress of the United States of America prohibiting the union of an American woman with a Filipino.

3. The phrase "historically-determined" is taken from my interview with Nick de Ocampo. He uses the phrase to indicate that a musical film sub-genre came before or after a particular sub-genre.

4. This estimate is based on collated data from different sources: first, a listing was done based on internet blog sites, flyers, and magazine articles and second, the listing is presented to Filipino classic film collectors who are then asked which films in the list are available or are extant.

5. Komedya is a Filipino theater tradition that describes the conflict between Christians and Moslems. Also referred to as "moro-moro," it was prevalent during the Spanish era and was used as a means to propagate Christianity. This theater tradition is still being performed to this date in the different regions of the Philippines.

6. This film was shown in the same period when the popularity of Hollywood child star Shirley Temple was at its peak. 
7. The sarswela film plays a significant role in the appreciation of Tagalog-musical films. Its impact on today's television shows is quite evident in a lot of recently produced teleseryes that are set in pastoral scenes and promote time-honored values.

8. See Prospero Covar's "Kaalamang Bayang Dalumat ng Pagkataong Pilipino" in Professional Chair Papers Series no.95-4. 


\section{The Language of Kundiman in Films: Awa at Pag-asa}

The kundiman is a song of love held in high esteem, weaving melody, text, and harmony into an expression that is Tagalog in thought and deed. It expresses the lofty sentiment of love and heroism in a melancholy mood (Hila 7). The kundiman basically expresses unrequited love as it conveys the Tagalog's sense of devotion, dedication, and patriotism.

The kundiman was referred to as "Cancion Filipina," manifesting a conscious effort by Tagalog composers to develop a song form that would best emulate the Tagalog spirit (Coroza). The transformation of the song from a unitary folk form exemplified through "Jocelynang Baliuag" (Molina 15) to a binary or ternary art song is attributed to the formal musical schooling of prominent kundiman composers, namely Francisco Santiago, Bonifacio Abdon, and Nicanor Abelardo. Different from the other local song forms, its melody with its distinct character that seems "to transcend the metric structure" (De Leon E1) is haunting. As De Leon points out, "The emotion captured by the kundiman is one of affectionate probing, exploring, sensing, and empathizing with the object of love and devotion, whether it is a person, community, country, spiritual symbol or ideal” (De Leon E1). 
The minor-major tonality gives the song an even wider palette of pitches to suitably express its text. The song emits a strong pleading-feel from its text coloring. It is rendered in triple meter, considered the most "spiritual" among the simple meters (De Leon E1) and together with its slow tempo, gives the music and text its ethereal feel to a point, devotional, expressing the Tagalog's inner thoughts and feelings.

The kundiman harmony is another factor that sets the song apart from other Tagalog vocal genres. It uses chordal progression that is distinct from other Filipino love songs. Harmonic dissonances, chromatic suspensions, and extensive use of non-chordal tones effectively support the melody in bringing out nuances within the text.

Prominent poets and playwrights wrote the texts of Tagalog kundiman by composers such as Santiago, Abdon, and Abelardo. For example, Abelardo's kundiman, "Bituing Marikit," was written by Servando de los Angeles; Kundiman ng Luha by Jose Corazon de Jesus; and Mutya ng Pasig by Deogracias Rosario. The text for Santiago's “Anak Dalita” was also by Rosario and that of Pakiusap and "Madaling Araw" were jointly written by de Jesus and Jesus Balmori.

The kundiman is timeless as exemplified by "Bayan Ko," penned by de Jesus with music composed by Constancio de Guzman. This kundiman from Severino Reyes' sarswela Walang Sugat reflects the events that transpired more than a century ago yet it also became the "hymn" of the first EDSA People Power Revolution in 1986. Like "Jocelynang Baliwag" that stirred the sentiments and moved the Filipino revolutionaries to unite and fight against Spain, "Bayan Ko" became the rallying point of what is popularly known today as People Power.

The kundiman composed by the triumvirate, Santiago, Abdon, and Abelardo, had been created during the first decades of the twentieth century, a juncture when emotions were running high among Filipinos because of the atrocities committed against them during the Philippine-American War. Their text was masked to avoid attention from American authorities who may consider the songs seditious. ${ }^{1}$ The deep expression of emotion may have also influenced the melodic lines' chromatic and dissonant character. Chromaticism creates a precarious feel signifying troubled feelings, unhappiness, and unrequited love. The experience of the Tagalogs under 
Spanish rule and their disappointment with the Americans who fought the natives brutally and in a genocidal manner (Francia 146) were the factors that shaped the disconsolate "awa" character. The desire and hope, or pag-asa, for national independence were constantly kindled despite years of struggle towards the attainment of freedom and liberty.

I present several interpretations of how the kundiman expresses an extra-musical message through the sensitive and artistic union of melody and text. An example is Abelardo's kundiman "Nasaan Ka Irog" where the song opens with the question, "Nasaan ka irog?" The downward step-wise melody gives the color of the emotion of a pleading lover looking for his loved one, more than simply asking a question. This is then followed by a long, lyrical, and chromatic melodic phrase that heightens the emotion, only to calm down in the next phrase as the melody relaxes and moves downward to end with a question (see notation 1 ).

\section{Notation 1}

Excerpt: Part 1 Opening from "Nasaan ka Irog?" by N. Abelardo
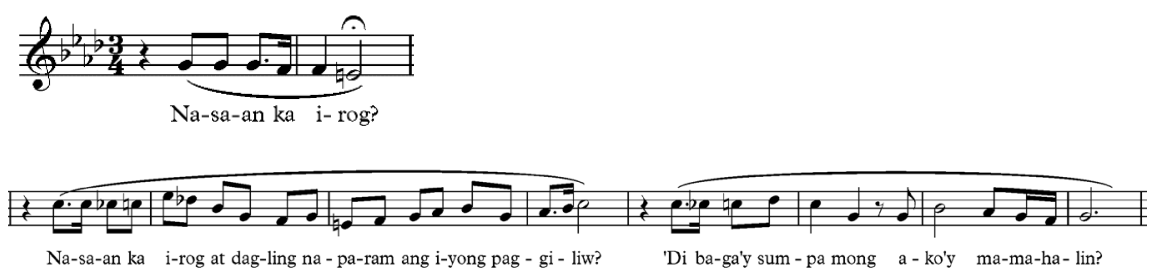

The song proceeds with another long lyrical phrase, similar to the above second phrase, then makes a dramatic octave jump for an impassioned plea at “subalit nasaan..." (see notation 2).

Notation 2

Excerpt: Two Phrases Expressing a Plea from "Nasaan ka Irog"

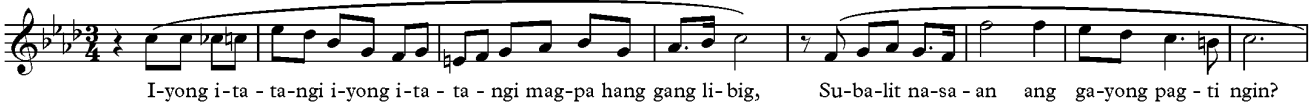


The following four phrases become dynamic with the dramatic lyrical melody that shows the agitation of the lover as he begs for answers on whether his love would be reciprocated or not (see notation 3).

Notation 3

Excerpt of four phrases from "Nasaan ka Irog"

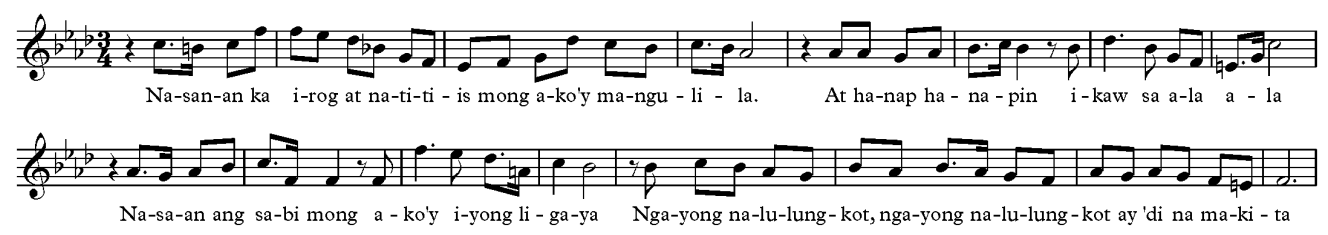

The first part, then, ends with a reminder (see notation 4).

Notation 4

Excerpt: Part 1 ending of "Nasaan ka Irog?"

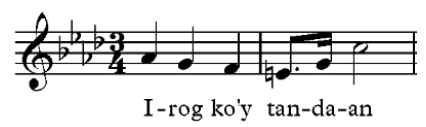

The second part is in the relative major (F), with the first line in a chromatic but lyrical line. The following phrase becomes lyrical and dramatic with the jump at phrase ending and the establishment of a major tonality the major tonality, giving it a refreshingly light melody, in contrast to the heavy feel of the first part in minor tonality (see notation 5).

Notation 5

Excerpt: Part 2 opening of "Nasaan ka Irog?"

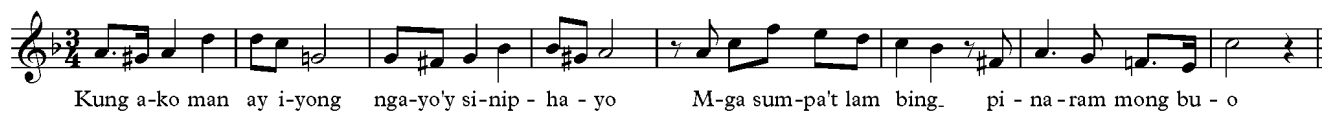


What follows is a dramatic melody that climaxes with the line "at hindi mag-lalaho...," which expresses a love that shall not fade, and if proven unrequited shall bear witness to an expression of love that becomes eternal. The phrase and the part, then, resolves to its tonic (see notation 6).

Notation 6

Excerpt of melody expressing eternal love from "Nasaan ka Irog?"

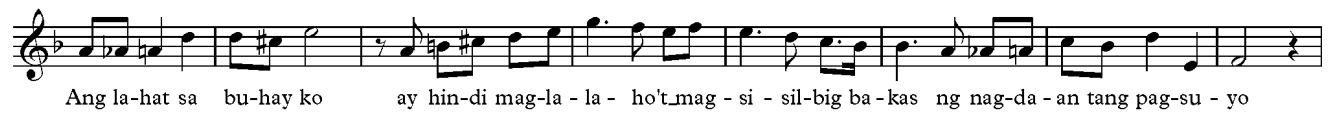

This kundiman ends with the first question, still expressing that the love is unrequited, with hope springing eternal (see notation 7).

\section{Notation 7}

Excerpt: Part 2 ending of "Nasaan ka Irog?"

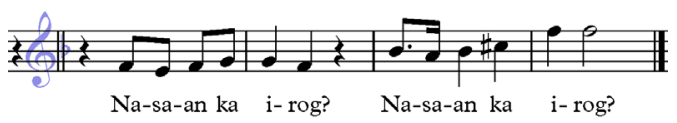

Codes, as well as semiotics in music, indicate that a minor melody or a downward line signifies sadness, while the major tonality/scale or an upward direction brings brightness and joy, representing the kundiman's "awa at pag-asa." Taking as an example the opening phrase, which textually is the same as the closing phrase, signifies difference in emotions due to the direction of the melody (see notation 8).

\section{Notation 8}

Comparing the opening and closing phrases of "Nasaan ka Irog?"

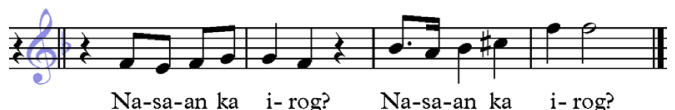

OPENING PHRASE 


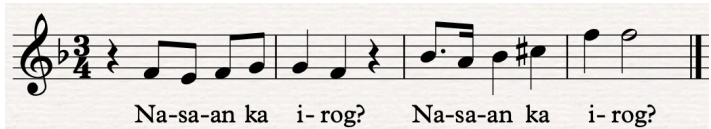

CLOSING PHRASE

Although both phrases ask questions, the downward melody connotes desolation while the upward melody suggests hope. Thus, the two phrases, even if they have the same text, have different meanings indicated by their melodic contour.

Another example is "Anak Dalita" (1917), composed by Francisco Santiago based on text written in Tagalog by Deogracias Rosario and transcribed in Spanish by Jesus Balmori. The song describes a destitute child, weeping and begging that he be loved in return. The melodic contour shows a pattern of up-downward phrasing for the first four lines, signifying a feeling of being lowly. Upward movement at phrase beginnings implies a cry or wail, ending on a low note expressing humility and the desire for the pleading to be heard (see notation 9).

\section{Notation 9}

Excerpt: Opening of "Anak Dalita" by F. Santiago

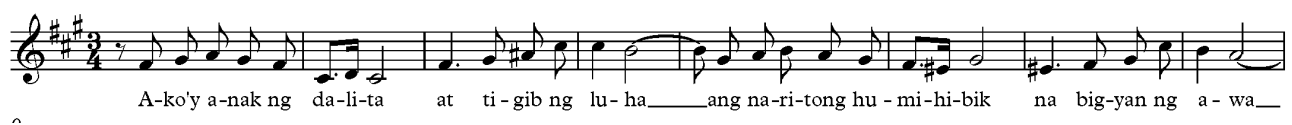

The second part of "Anak Dalita," marked "animato," conveys hope, as the melody creates a general upward direction even as the text expresses death (see notation 10).

Notation 10

Excerpt: Part 2 of "Anak Dalita"

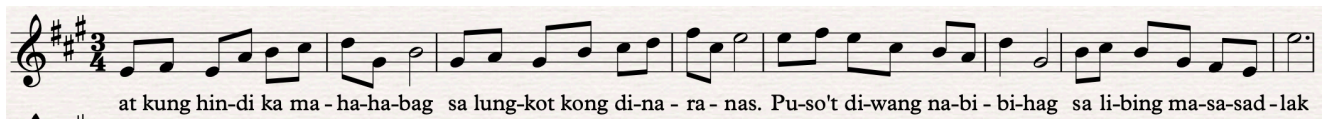


This leads to the third part that modulates to its relative major (A), signifying hope. One immediately moves from a feeling of sadness to one of openness as the sound of the major third takes the listener to a spirited outlook. The melodic contour of the third part constantly goes in an upward direction that climaxes as the kundiman ends (see notation 11).

\section{Notation 11}

Excerpt: Part 3 of "Anak Dalita"

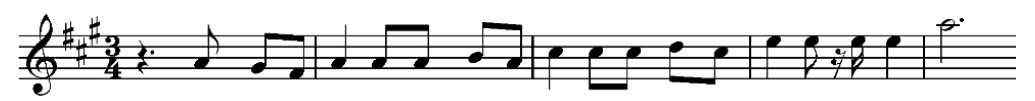

Ang 'yong i - hu-log ang 'yong i - hu-log bu-hay pag - a - sa pag-a - sa!

In both "Nasaan Ka Irog" and "Anak Dalita," we find another character of the kundiman in which the melody phrase ends on the second beat, displacing the downbeat of the triple meter. A series of eighth notes comprises a melodic line which at the second measure ends on the second beat (see notations 12 and 13).

Notation 12

Excerpt: Part 2 opening of "Nasaan ka Irog?"

$1 \quad 2-3 \longrightarrow \begin{array}{llll}1 & 2-3 & 2-3\end{array}$

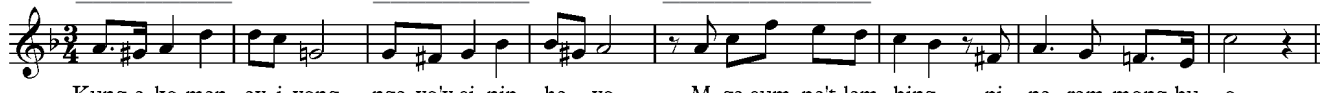

Kung a-ko man ay i-yong nga-yo'y si-nip - ha - yo M-ga sum-pa't lam bing- pi - na-ram mong bu - o

Notation 13

Excerpt: Part 2 of "Anak Dalita"

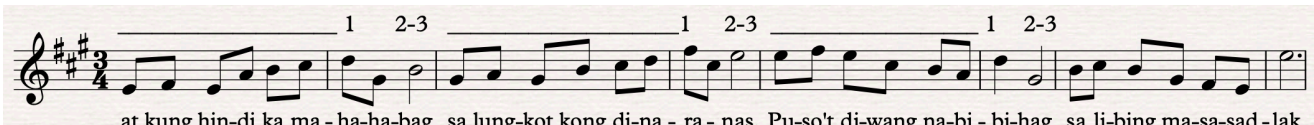


Constancio de Guzman's Bayan Ko distinctly illustrates the same pattern (see notation 14):

Notation 14

Excerpt of "Bayan Ko"

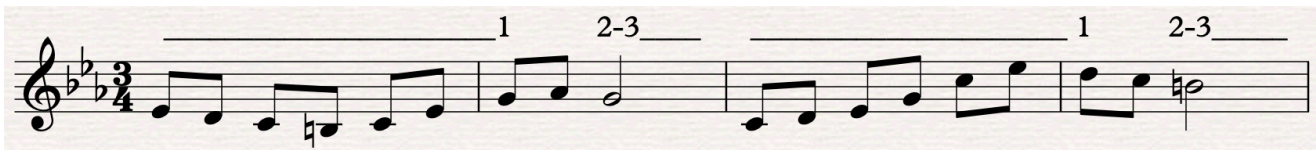

Ang ba-yan kong Pi - li - pi__ nas Lu-pa-in ng gin-to't bu-lak-lak

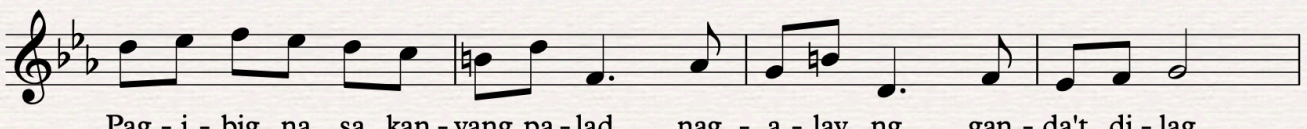

Pag-i - big na sa kan-yang pa-lad nag - a - lay ng gan - da't di-lag

This character of the kundiman, as pointed out by De Leon, is found in kundiman which may not have the major-minor form found in the kundiman of Abelardo and others. A fine example is "Jocelynang Baliwag" also referred to as the "Kundiman ng Himagsikan" (see notation 15).

Notation 15

Excerpt of "Jocelynang Baliwag"

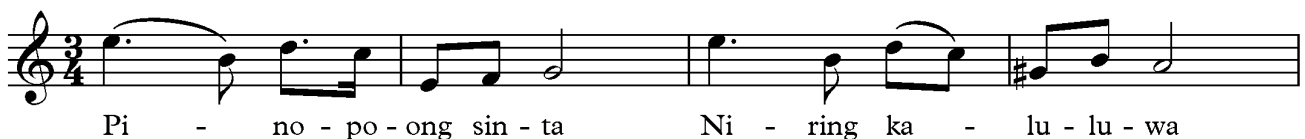

It is to be noted that Jocelynang Baliwag does not contain any text that may have a direct or indirect reference to war or revolution. Even its melodic line, paradoxical for what is expected to be march-like, is a flowing melody that may even be considered a lullaby. Molina points out that it the memory of peacetime days with their mothers, wives, and children that has inspired the katipuneros to fight for the struggle for freedom. The song becomes an inspiration to fight for the mothers and for the motherland. 
The text of the kundiman may express romance, love of country, faith, and unrequited love. The beauty of the language written into phrases by poets and playwrights contributes to the lofty character of the kundiman. In the following examples, one can easily perceive the musicality of the lines through the inflection of the Tagalog text. Kundiman ng Luha (1924), composed by Abelardo based on a text by de Jesus, speaks of a man pleading for love:

Paraluman sa pinto ng iyong dibdib

Isang puso ang naritong humihibik

Kaluluwang luksang-luksa at may sakit

Pagbuksan mo't damayan

Kahit man lang saglit

Tingin yaring matang luha'y bumubukal

Humihinging awa mo't pagmamahal

Damhin mo rin ang dibdib kong namamanglaw

Yaring pusong sa pagsinta'y mamamatay.

Bituing Marikit (1926), composed by Abelardo with text by de los Angeles for the sarswela "Dakilang Punglo" (1926), compares a lady to a star whose light provides hope. The suitor then pleads for attention:

Bituing marikit sa gabi ng buhay

Ang bawat kislap mo'y ligaya ang taglay

Lapitan mo ako, halina Bituin!

At ating pag-isahin ang mga damdamin

\section{Ang sabik kong diwa'y huwag mong uhawin}

Sa batis ng iyong wagas na paggiliw.

"Madaling Araw," composed by Santiago and text by de Jesus, has its connection with the last chapter of Jose Rizal's Noli Me Tangere entitled "Christmas Eve" (Coroza). In the final chapter, Basilio finds his mother Sisa who recognizes him before her death. Elias instructs Basilio to gather wood to burn their two bodies into ashes. In Elias' final moments, he utters: 
I die without seeing the dawn brighten over my native land!

You, who have it to see, welcome it-

and forget not those who have fallen during the night!"

He raised his eyes to the sky and his lips continued to move, as if uttering a prayer.

Then he bowed his head and sank slowly to the earth.

The sentiments of Elias are captured in the following lines as written by de Jesus in the kundiman, "Madaling Araw," where motherland is referred to as mutya:

Sa gitna ng karimlan,

Mag madaling araw ka

At ako ay lawitan ng habag at pagsinta.

Kung ako'y mamatay sa lungkot,

Nyaring buhay

Lumapit ka lang at mabubuhay

At kung magkagayon

Mutya, Mapalad ang buhay ko

Magdaranas ng tuwa dahil sa iyo.

The above examples of kundiman by Abelardo and Santiago provide an understanding of pity, appeal for attention, and affection. Words like "awa" and "mamatay" emphasize the gravity of emotions involved, making unreciprocated love almost comparable to a level of spirituality.

The final part of a kundiman almost always expresses a sense of hope and redemption. The contrast between minor and major signifies despondence and lightheartedness, respectively. The text expressing deliverance and hope of the kundiman's final part gives the listener a positive stroke that brightens up the whole piece (see lines below in bold letters).

In the final part of "Anak Dalita":

Sa dilim ng gabi aking nilalamay

Tanging larawan mo ang nagiging ilaw

Kung ikaw ay mahimbing sa gitna ng dilim 
Ay iyong ihulog puso mo sa akin

Ang iyong ihulog, ang iyong ihulog

Buhay, pag-asa, pag-asa

In the final part of Pakiusap:

Kung sakali ma't salat sa yama't pangarap,

May isang sumpang wagas,

Ang aking paglingap.

Pakiusap ko sa iyo kaawaan mo ako,

Kahit mamatay, pag-ibig ko'y minsan lamang.

Iniibig kita, magpakailan pa man.

In the final part of Kundiman ng Luha:

Ilaglag mo ang panyo mong may pabango

Papahiran ko ang luha ng puso ko

Ah! pag-ibig kung ang oo mo ay matamo

Ah! pag-ibig kung ang oo mo ay matamo.

Hanggang sa hukay, hanggang sa hukay

Magkasama ikaw at ako!

In the final part of Bituing Marikit:

Lapitan mo ako, halina Bituin!

At ating pag-isahin ang mga damdamin

Ang sabik kong diwa'y huwag mong uhawin

Sa batis na iyong wagas na paggiliw

In the final part of Mutya ng Pasig:

Ang lakas ko ay nalipat,

Sa puso't dibdib ng lahat;

Kung nais ninyong akoy mabuhay,

Pag-ibig ko'y inyong ibigay. 
In the final part of "Madaling Araw":

Madaling araw na sinta

Liwanag ko't tanglaw

Halina Irog ko at

Mahalin mo ako

Mutyang mapalad na ang buhay ko

Nang dahilan sa ganda mo,

Madaling araw na sinta

Liwang ko't tanglaw

Halina Irog ko

At mahalin mo ako

Manungaw ka liyag

The kundiman created impressions of awa at pag-asa on the Tagalog psyche. It inspired the producers and directors to create films expressing the extra-musical meaning of awa at pag-asa embedded in the narratives of the kundiman melodrama. Kundiman melodrama films were not meant to exhibit attributes of the song but to express the subliminal sentiment and thoughts of a community who shared experiences, in effect binding them in communion. The kundiman is a reminder of the past. It is a song expressing the sentiments of a people and embodying an imaginary of mercy (awa) and hope (pag-asa).

The kundiman's influence goes beyond its musical elements and qualities as it has shaped a sub-genre of Filipino film through meanings that rest beneath its aurality. The kundiman melodrama film, on the other hand, incognizant of its contribution to the song form, has become a medium to further substantiate the significance of the kundiman in its contribution to the story of the past of the people's response to its experience under the colonizers.

\section{Kundiman in Films}

Kundiman melodrama is a Tagalog melodrama film with music playing an essential role in enhancing the cinematic experience. The kundiman as used in films mimics the extra-musical meaning of mercy and hope (awa 
at pag-asa) signified through its melodic character, text, and tonality. The kundiman transcends the aural dimension and expresses pain, sorrow, perseverance, and hope. Moreover, the kundiman melodrama is heavy in terms of histrionics compared to the film sarswela. Viewers may consider kundiman melodrama excessive, but an understanding of the kundiman provides knowledge that it goes beyond drama for drama's sake. The kundiman melodrama is similar to a previous theater form called drama-musical where pre-made songs are inserted in the narrative.

Most literature on the kundiman points to its unrequited love and pleading nature. In this connection, I take the parallel tonal major key section of a kundiman as another salient point for it creates a symbolism of hope while the tonal minor key suggests mercy. The minor and major keys musically articulate the dyad awa at pag-asa as expressed in the kundiman (see Table 1).

\begin{tabular}{|c|c|}
\hline \multicolumn{2}{|c|}{ Kundiman } \\
\hline Awa & Pag-asa \\
\hline \multicolumn{2}{|c|}{ Extra-musical meaning } \\
\hline $\begin{array}{l}\text { First part: } \\
\text { Minor key and chromatic melody pro- } \\
\text { duces tonal imbalance that makes the } \\
\text { text of mercy, self-pity and sacrifice truly } \\
\text { expressive }\end{array}$ & $\begin{array}{l}\text { Second/ Third part } \\
\text { Major key, melody turns "bright" with } \\
\text { the major third. Melody is dramatic and } \\
\text { lyrical as it reaches the climax which } \\
\text { expresses hope that comes after the pain }\end{array}$ \\
\hline
\end{tabular}

Table 1. Kundiman awa at pag-asa as extra-musical meaning

Six (6) of the nine (9) films are kundiman melodramas. These are: Ang Tangi Kong Pag-ibig, Sarung Banggi, Anak Dalita, Mutya ng Pasig, Maala-ala Mo Kaya, and Kundiman ng Lahi. The conflict in the narrative requires self-sacrifice for redemption. Characters in the film, despite affirmations, insist on one's unworthiness. Explanations of how the extra-musical awa at pag-asa is laid parallel to the narrative and/or characters of four kundiman melodrama films are illustrated in the following pages (see Tables 2-4): 


\begin{tabular}{|c|c|}
\hline \multicolumn{2}{|c|}{ ANG TANGI KONG PAG-IBIG } \\
\hline AWA & PAGASA \\
\hline $\begin{array}{l}\text { Jovita - } \\
\text { - Beautiful and talented, works in a night } \\
\text { club. Hounded by rumors. She leaves } \\
\text { for home, meets Sergio and plans to } \\
\text { get married. On her wedding day she is } \\
\text { abducted by her former employer. } \\
\text { - She finds herself underserving of Ser- } \\
\text { gio's love because of her past. Enters } \\
\text { the nunnery. }\end{array}$ & \\
\hline \multicolumn{2}{|c|}{$\begin{array}{l}\text { - As medical assistant she meets Sergio as a patient. Sergio tries to win her back and } \\
\text { insist that she is undeserving. } \\
\text { - The superior of the nunnery convinces Jovita to return as she cannot run away } \\
\text { from the truth. }\end{array}$} \\
\hline & $\begin{array}{l}\text { - Sergio returns to nunnery to wait for } \\
\text { Jovita. } \\
\text { - Jovita leaves and joins Serio. }\end{array}$ \\
\hline
\end{tabular}

Table 2. Kundiman melodrama "Ang Tangi Kong Pag-ibig"

\begin{tabular}{|l|l|}
\hline \multicolumn{2}{|c|}{ ANAK DALITA } \\
\hline \multicolumn{1}{|c|}{ AWA } \\
\hline VIC: \\
- Stoic medalled soldier, sculptor by pro- \\
fession, does not get the recognition he \\
expects. \\
- His mother dies upon his return, \\
is guilty that he has not served his \\
mother. \\
- Loses his right arm and is not able to \\
sculpt after serving as soldier. \\
TITA: \\
- Hostess in a nearby club, took care of \\
Vic's mother. \\
- Partner of Vic to whom she shared her \\
place for him to stay. Quarrels with Vic \\
$\quad$ would result to physical manhandling. \\
COMMUNITY INSIDE THE RUINS: \\
- Victims of war and poverty \\
- Squatting inside church
\end{tabular}


FR FIDEL:

- Gives chance to Vic by asking him to do sculpting work of religious images.

- Pastor of the community inside church ruins, finding a place for the settlers to stay permanently.

TITA:

- Saves Vic from the crime syndicate he was lured to join.

- Vic is saved by Tita, they leave the ruins to start life anew

- The community leaves the ruins for a better life. Church will undergo restoration for the faithful.

Table 3. Kundiman melodrama "Anak Dalita"

\begin{tabular}{|c|c|}
\hline \multicolumn{2}{|c|}{ KUNDIMAN NG LAHI } \\
\hline AWA & PAG-ASA \\
\hline $\begin{array}{l}\text { ISANG: (Signifier for motherland) } \\
\text { Sa gawaing bukid, tayo'y magsikap } \\
\text { Sa tulong ng bisig, tayo'y uunlad } \\
\text { Sa tulo ng pawis, ay maliligtas } \\
\text { Ang lahi nating tunay na naghihirap } \\
\\
\text { - Her mother dies, she takes all liabilities } \\
\text { left behind by her mother. She is in- } \\
\text { debted to her aunt and uncle. } \\
\text { - Her uncle has sexual desires for her. } \\
\text { - Isang leaves home and enters cabaret } \\
\text { to avoid his uncle. } \\
\text { - She gets married to Tonyo her boyfriend. } \\
\text { - Tonyo learns of her past, drives her away. }\end{array}$ & \\
\hline \multicolumn{2}{|c|}{$\begin{array}{l}\text { - Tonyo learns that his fears are untrue. } \\
\text { - } \text { - Tuntie learns of the incidents between Isang and her husband, Teryo. } \\
\text { - Teryo deathbed admits his faults and asks for forgiveness }\end{array}$} \\
\hline & $\begin{array}{l}\text { - Tonyo returns to Isang. } \\
\text { - Auntie joins the household to be of } \\
\text { help to Isang. } \\
\text { At sa wakas } \\
\text { Ng mahawi ang ulap } \\
\text { Nagtagumpay rin ang pagtitiis } \\
\text { Ang katapatan sa sumpaan } \\
\text { Ang dalisay na pag-ibig ng babaeng } \\
\text { Pilipina } \\
\text { Ang dangal ng lahing kayumanggi! }\end{array}$ \\
\hline
\end{tabular}

Table 4. Kundiman melodrama Kundiman ng Lahi 
The sacrifice (pagtitika) element found in kundiman's awa may be traced back to the years of Spanish conquest and revolution when Tagalogs, then called indios, were deprived of dignity, of the Spanish language, and basic freedoms. With the arrival of the Americans, the locals set their sights on the much-desired emancipation. Unknown to them, the Americans came to satisfy their own needs more than to liberate the country. Hundreds of years under Spain and a decade of hostilities with America displaced the Tagalog from his true being. Perhaps the experience with the colonizers has contributed in shaping the Tagalog loob, where the true self is resolved through introspection.

Filipino scholars have articulated various concepts of loob. Though different in approach and interpretation, all propositions point to the inward direction of thought to understand the Tagalog in particular. Albert Alejo, S.J. explicates $l o o b$ as the process of introspection that leads to a better understanding of the external. Loob commences a process that transports the person to his inner self, searching his personhood. Understanding the true being of a person facilitates personal progress. It is coming to terms with the reality of the self that one is able to pursue with equanimity. In Pasyon and Revolution, Reynaldo Ileto points out that loob is not a static core of a person but is pro-active with its physical surroundings, society, and universe. He adds that the state of a person's loob can be seen through the events transpiring within the community. Ileto, in order to understand the meaning of the revolution, draws his codes from the pasyon and other materials like folk songs which the common people hold close. The concept of loob is imbedded in the Tagalog pasyon, but it is believed that the concept dates back before the pasyon appeared.

A further discussion of loob that interconnects with the Tagalog imaginary is brought forth by Jose de Mesa, stating that loob is the guiding principle that binds the intellectual, emotional, volitional, and ethical dimensions of a person (Ileto 30). It is a concept that is relational and is two-pronged - one that is directed toward God and the other toward his fellowmen. Loob highlights the concepts of utang na loob and kagandahang loob. Utang na loob applies to a human relationship described as pakikipag-kapwa tao and to being indebted to someone for a favor granted. Kagandahang loob aptly illustrates the love of God for man (Alejo 24).

However, Vicente Rafael presents a dissenting view on loob vis-à-vis that of de Mesa and Ileto. For him, loob is a hollow expression that refers 
to a multiplicity of meanings. The inner-self is likened to a void vessel that attains value if filled from outside. He believes that loob is a resultant concept of connivance used by the Spanish authorities (Alejo 37-42). Rafael states that because subjugation is non-native, the colonizers did not fulfill its objective of achieving inner transformation for its subjects.

Another discussion of loob comes from Emmanuel Lacaba who proposed two possible natures of loob. One is through a metaphorical view based on the Tagalog legend of Bernardo Carpio which is linked to the historical reality of Philippine colonization. The second view is derived from Hegelian logical dialectics (Alejo 12) wherein Lacaba attributes the native's isolation to a labyrinth, a deep and confusing cave, (Alejo 12) to colonial subjugation. The cave is loob where the thought is structuralized (yungib ng kaisipang Pilipino). As an effect of colonization, the Tagalog lost home (loob) and was forced out of our being. The kundiman and sarswela, being local productions of the Tagalog, are significant expressions of loob in itself. Unrequited love of the kundiman and the animosity expressed in the stage sarswela are codes of the physical environment, which the Tagalog shares in communion. The innate strength of loob needs the realization and acceptance of past truth to overcome physical realities and move beyond the conditions (Alejo 23-30). Despite differing dominant concepts of awa at pag-asa in kundiman, and the lungsod at nayon in sarswela, loob weaves these expressions into an imaginary. The discourse on Tagalog loob by various scholars highlights the devotion of the Tagalog to the enamored, transcending the temporal into the deep expression of the spirit.

The following chapter, discussing synopsis and musical analysis, illustrates the creativity of the artisans in the films expressing the imagining identity of the Tagalog as it has been, and shall always be associated with the character of the people.

\section{Note}

1. The Sedition Law of 1901 enacted during the American colonial period prohibited any Filipino from the public manifestation of nationalistic feelings or the advocacy of independence from the United States. Violators were severely punished, imprisoned, or worse. 


\section{Filipino Films in Focus: Synopsis and Musical Analysis}

This chapter presents the synopsis of films, musical analyses, and sub-genre discussions. The methodological approach for analysis is drawn from the work of Juan Roque Chattah who classified film music into analogues (analogy) and associations. Analogy is sub-divided into sonic (onomatopoea) analogue where music mimics the visual component, following the visual movement through musical elements like timbre, articulation, register, and dynamics. The other sub-component is called embodied analogue where musical parameters conceptualize mood or bodily state through mimesis. It describes feelings or state of emotion through harmonic dissonance and tonality such as the major and minor mode.

Association is sub-divided into intra-opus, which is similar to leitmotif where short musical phrases are associated with a character, place or event, and extra-opus, which may have been used outside the film or is pre-existent. The function of extra-opus music is to set the time, period, gender, and ethnicity of characters within the narrative.

All nine films feature different styles in expressing the Tagalog imaginary at the aural and visual level. Some films convey this through a character, 
sub-plot, or song, while others are embedded within the whole narrative. The aural and visual elements of the narrative then collectively create an expression that shows one or more concepts of loob, awa at pag-asa or lungsod at nayon. Moreover, sarswela and kundiman songs cross over film genres whereby kundiman is utilized in sarswela film and sarswela music in kundiman melodrama as well.

\section{TUNAY NA INA (1939)'}

Tunay Na Ina (1939) is one of the five pre-World War II extant Filipino films, produced by Luis Nolasco under Excelsior Pictures. The film was written and directed by Octavio Silos. Music for the film was provided by Miguel Velarde, Jr. who wrote the danza "Buhat" with Dominador Santiago as lyricist. This song was revived sometime in the seventies by The New Minstrels, a popular showband, and was widely accepted by the radio-listening public. The film Tunay na Ina exhibits the character of the Tagalog in the midst of socio-cultural transformation brought about by the influx of American culture.

Tunay na Ina is a sarswela film. The film carries a story of hope amidst all trials and challenges faced in society. The narrative affirms the norm of a community, its cultural practices and traditions that bring people together. The music of the film features a contrast of Tagalog folk and Americaninspired songs.

Magdalena del Sol is the biological mother of Tita, the main character of the film. Magdalena is perceived to be a sinner from the point of view of her father Don Alberto and of her husband, Roberto. Don Alberto like Roberto represents the head of a Tagalog family, a loving and caring father and husband, and at the same time, proud and uncompromising on issues of maidenhood. Anday, the stepmother of Tita, is a picture of strength despite her limited financial resources. She openly accepts the request of Faustina to adopt and to take care of the baby, Tita, by herself. Finally, Tita the young girl is the most complex of all characters. Her grandfather gives her away to Anday, the household help, after she was born. She roams the streets begging for alms experiencing hardships at an early age. She has to choose between someone whom she had learned to love (Anday) and her biological mother (Magdalena). Despite her 
situation, Tita exhibits her talent and strength going through the trials of her young life.

The music of the film comprises the theme song, "Buhat," "Maawa Maawa," "Ay Ay!" and "Maligayang Pasko." "Buhat" is a danza composed in 1939 by Mike Velarde with text by Dominador Santiago. It follows the minor-major pattern of the kundiman. "Maawa, Maawa" sung by Tita while asking for alms, also follows the minor-major kundiman form. Likewise, the musical lines consisting of successive eighth notes leading to the next measure where the line ends on the second beat makes it significantly a kundiman (see notation 1 ).

\section{Notation 1}

\section{Excerpt from "Maawa, Maawa"}

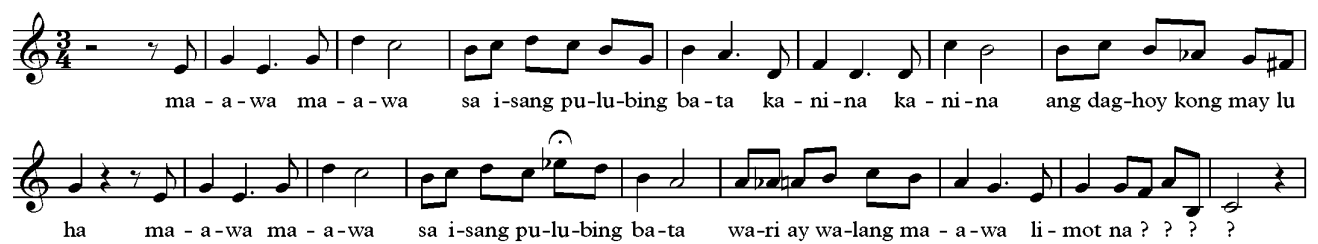

The song "Ay Ay!" has a folk-like melody in triple meter accompanied by a rondalla ensemble, heard at a community Christmas program scene. The song follows a folk song-like character set to comical text. The verses of "Maligayang Pasko!" also take a folk flavor that leads to an "Americanized" chorus part. The scene shows Tita with other young girls singing the song wearing band majorette attires. Tita, in this scene, mimics American child star Shirley Temple who was at the peak of her career in the United States when this Tagalog film was produced.

The choice of songs, including non-diegetic music, ${ }^{3}$ reflects Hispanic and American influences. The song styles signify wide ranging themes from sacrifice and piety to celebration, redemption and hope. The mix of nuances from colonial-influenced music and Filipino airs creates a hybrid soundscape. The Latin "Ave Maria," the songs of Tita, and the American-inspired visual design in the latter part of the movie all point to the country at the crossroads of change acculturating American ways of life into Filipino traditions. Likewise, "Ave Maria" aside from setting the tone of the mourning 
scene, serves as an extra-opus association to the prominent socio-cultural status of the family of Magdalena. The narrative exhibits diversity of cultures and shows how the Tagalog character is shaped by the socio-cultural and economic conditions. Tita symbolizes $l o o b$ as she undergoes introspection as a rejected child who experiences desolation. She eventually redeems herself from the hardships of destitution through the goodness of self, shared with everyone around creating a denoument that brings hope to all the characters.

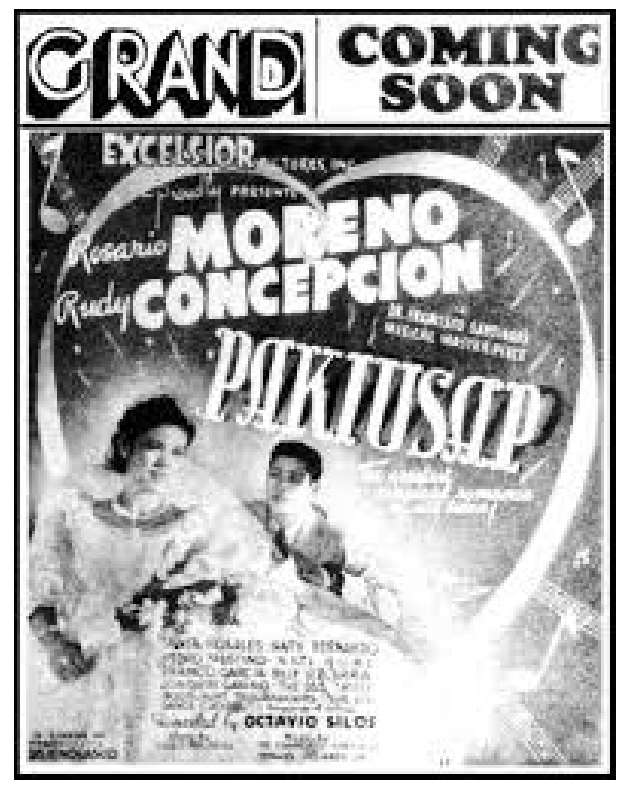

Fig. 2 Promotional poster of "Pakiusap" (1940). Reprinted by permission of Simon Santos.

\section{PAKIUSAP (1940) ${ }^{4}$}

Pakiusap (1940) is one of the four extant pre-World War II Filipino films that we have today. The film was produced by Excelsior Pictures, with story by Luis F. Nolasco and Octavio Silos, the latter also serving as Director of the film. The music was handled by Dr Francisco Santiago, one of the foremost 
Filipino composers, assisted by Miguel Velarde Jr. and Juan Silos Jr., both of whom became prominent film composers in succeeding productions of the different Filipino film outfits.

Pakiusap is a sarswela film, a love story between the rich and the poor. Mang Teong, the father of Amparing, who works as a farmer in Don Andres' hacienda, turns down suitors as he distrusts anyone belonging to the upper strata of society. Despite the limited financial resources of his family, Mang Teong treasures the integrity that the family has upheld through the years. The narrative revolves around the travails of hacienderos Don Andres and his son Ernesto, each of whom are on their respective quest to win the affection of Amparing.

Don Andres gifts Amparing and Mang Teong with favors in exchange for Amparing's love and the father's approval. However, instead of getting Amparing's affection, he earns the ire of Mang Teong. Ernesto, knowing that Mang Teong will never entertain rich suitors, dresses down from his usual garb of white shirt and white pants ${ }^{5}$ to the native barong Tagalog and maintains an image of an ordinary neighbor for most part of the film. Ernesto does the traditional harana to express his admiration for the lady (Scene 12; 0:13:45) after which he is able to constantly meet with Amparing. He assists her with her daily chores in keeping with the traditions of courtship (Scene 16; 0:21:54).

The film opens on a festive Christmas celebration with fourteen pairs dancing tinikling. This segues to "Buhay Bukid" (Scene 2; 0:03:17), showing the simplicity of life in the nayon. The diegetic and non-diegetic use of the kundiman Pakiusap predominates the film. A wide range of repertoire both classical to Filipino popular tunes are part of the film's soundscape. It includes the use of Bach's “Air in G String” as non-diegetic music for Scene 33; 1:06:00 and Wagner's "Treulich Geführt” (wedding scene parade at Scene 35: 1:12:08). The extra-opus association of the "Air in G String" establishes the mood as Magdalena desperately looks for money for her sick mother. "Treulich Geführt” instantly gives the idea of a wedding ceremony. Local music such as the marching band predominates the celebratory scenes of the film. The presence of the bamboo orchestra (Scene $38 ; 1: 16: 48)$ shows the importance of native bamboo music and its equal stature with western instruments. Celebrations complete with a fluvial parade for a big wedding (Scene 38; 1:16:48) and dramatic settings such as doing a 
harana on a banca (Scene 12; 0:13:56) show Filipino traditions and music which were mostly seen in the nayon rather than in the ciudad. The film establishes the value of self-worth of the locals in whatever economic strata as exemplified by Mang Teong and his family who do not give in to the enticement of gifts, favors, and the promise of a good life.

The title of the film was taken from a kundiman, Francisco Santiago's Pakiusap, the text of which is as follows:

Natutulog ka man, irog kong matimtiman

Tunghayan mo man lamang ang nagpapaalam

Dahan dahan mutya, buksan mo ang bintana,

Tanawin mo't kahabagan,

Ang sa iyo'y nagmamahal.

Kung sakali ma't salat sa yama't pangarap,

May isang sumpang wagas,

Ang aking paglingap.

Pakiusap ko sa iyo kaawaan mo ako,

Kahit mamatay, pag-ibig ko'y minsan lamang.

Iniibig kita, magpakailan pa man.

Most kundiman songs have lyrics that express optimism in the latter part using the major tonality. In Pakiusap, the height of the pleading with the text "Pakiusap ko sa 'yo kaawaan mo ako / Kahit mamatay, pag-ibig ko'y minsan lamang" is rendered in the climactic part of the kundiman that ends with a promise beyond mortality, where love will still prevail (see notation 2).

\section{Notation 2}

Excerpt of kundiman entitled Pakiusap

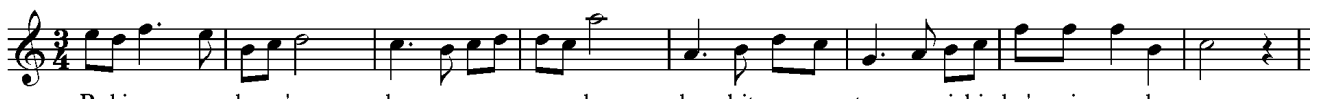

Paki-u - sap kosa'yo

ka - a waan moa-ko

ka - hit ma-ma-tay pag-i-big ko'y min-san la-mang 
The melodic contour becomes dramatic with the leap at " $a-k o$ " expressing both the passion and the plea. The film concludes with the wedding scene production (all-star cast) of Ernesto and Amparing, with the blessing of Don Andres.

The kundiman Pakiusap is utilized diegetically and non-diegetically six times throughout the film. Amparing and Ernesto exclusively render the song in several scenes. The use of the kundiman Pakiusap functions both as embodied analogue with the minor-major tonality expressing both happy and sad undertones parallel to awa at pag-asa. The song is an extra-opus association as it sets the period of the film to early American period when the song was composed. Ernesto first sings Pakiusap as his harana to Amparing and the end production scene features Ernesto and Amparing singing a duet with a chorus.

Another song "Giliw" (Scene 27; 0:58:33) is a danza showing Ernesto assisting Amparing with the freshly washed clothes. Penduco and a cast of male workers sing a novelty song "Ang Buhay nga ng Tao" (Scene 25; 0:52:26) about the exploits of Don Andres and Amparo and as a result, Penduco makes himself a true-to-form comico, a household helper who provides comic relief. Comicos, due to the nature of their proximity to the family, know more about their landlord ( $a m o$ ). The song "Ang Buhay nga ng Tao" exemplifies the comico role. There are several stingers to depict the character of Penduco in the film. These short musical materials serve both as sonic analogues and leitmotif for Penduco.

The kundiman contains underlying meanings beyond sensual love, thus, the film's narrative is interpreted as an expression of an imaginaryAmparing as the motherland, Don Andres with his mestizo looks as the colonizer, Penduco as the resilient Tagalog who puts up with anything while keeping himself sane and light-hearted, and Ernesto as the ideal Tagalog passing through the crossroads of acculturation while keeping his heritage intact. Ernesto signifies loob and lungsod at nayon when he removed his usual garb of white long-sleeved shirt and pleated pants worn by members of his economic class and changed into the native barong. The act is symbolic of upholding time-honored Filipino traditions in spite of his family's economic standing which normally adopts westernized lifestyle. The change represents a return-to-the-roots decision in order to achieve a life goal: transcending the temporal into the deep expression of the spirit for a future of hope. 


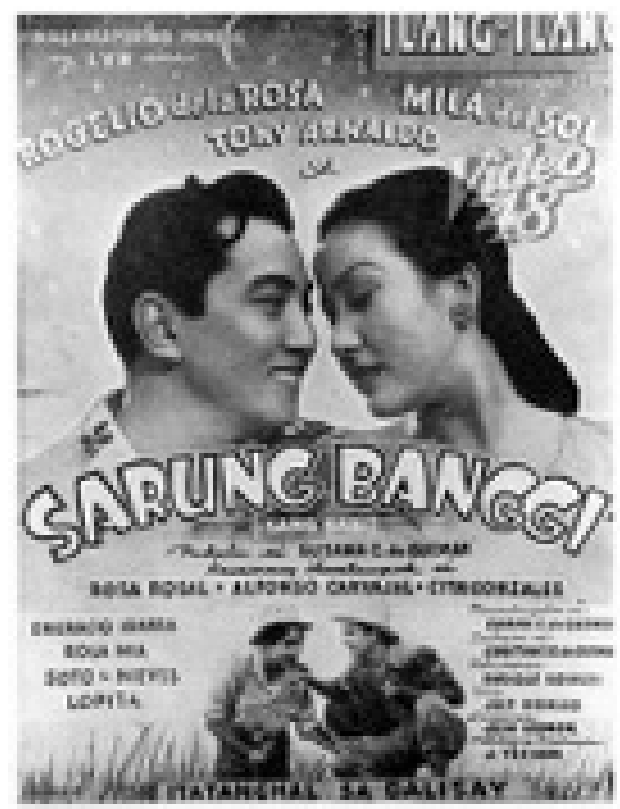

Fig. 3 Film promotion of the film Sarung Banggi in a page of Ilang-llang Magazine in 1947. Reprinted by permission of Simon Santos.

\section{SARUNG BANGGI (Isang Gabi) (1947)}

Sarung Banggi is the seventh and last film produced in 1947 by LVN Pictures. The story was written by Jose de Cordova and Susana C. de Guzman, the latter also directing the film. The musical director was Constancio de Guzman who was supported by Luis Evangelista.

Sarung Banggi is a sarswela film about childhood friends who meet again in their early adulthood, fall in love, and unite in holy matrimony. The film has songs in production scenes, totaling six in all. It opens with Nanding in a boat scene singing "Kaming mga Mangingisda" as a solo after which the other fishermen sing with him. (Scene 1; 0:00:11). The song is similar in melody to "Bahay Kubo," one of the most popular Tagalog folk melody used in a number of sarswela films. The similarity of melodic contour creates an extra-opus association of "Bahay Kubo" establishing the pastoral setting of the film (see notation 3). 
Notation 3

Excerpt of "Bahay Kubo" influenced folk melody.

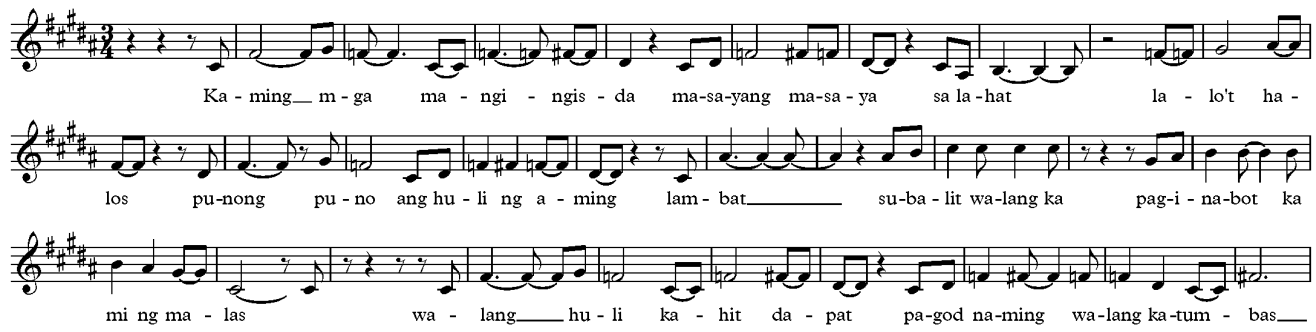

In Scene 21; 0:43:33, Nanding sings Sarung Banggi with his friends doing the voice parts in front of Rosa Rosal who portrays a movie actress in the film. Rosa, impressed by the talent and smitten by the charm of Nanding, endorses him for a movie role. The impromptu performance leads to an opportunity for Nanding to start a career in entertainment requiring him to move to Manila. His transfer to the lungsod creates an impression on his townmates that he develops a change of attitude and an arrogance which rural folks attribute to city dwellers. Nanding starts to introspect and decides to go back to his simple life. The narrative ends with Nanding returning home and coming to terms with the community, Marina, and her parents. In the last production scene, a surprise is prepared by Marina's father and Nanding's friend Manning, the community gathers, and on cue, all sing "Jingle Bells" (Scene 45; 1:30:04). The Tagalog text, unfortunately, is incomprehensible except for the first two lines of the chorus: "Ang Pasko, ang Pasko ay maligaya / Magdiwang, magdiwang...."

The film Sarung Banggi exhibits the lungsod at nayon dyad signified by Rosa and Nanding. When Nanding leaves for Manila to be a novice movie actor, his townmates think he had changed. The perceived change of attitude, which was disproved in the denouement, may be viewed as a misinterpretation of the ill effects of the lungsod on a person. Marina, the barrio lass with her clean and unselfish intentions, prods her husband-to-be to take the opportunity given by Rosa and is unsuspecting of the latter's premeditated plan to pursue her own affection for Nanding. Marina, showing her full support, gives her life savings to Nanding for his expenses in the city. 
She eventually realizes that Nanding is being pursued by Rosa and that he gave in to the desires of Rosa. Made helpless by the situation, Marina gets hurt and gives Nanding the freedom to do what his heart desires.

Nanding symbolizes the deep and devotional Tagalog, a fisherman who sings hymns in a local church choir as an apostolate. He shares his singing talent in church, hones it, and is eventually given the opportunity to become an artist. The film exhibits the innate treasure of a Catholic Tagalog: his faith and his music. Nanding personifies loob following the relational concept of Jose de Mesa (Alejo 29). Loob being two-pronged is directed toward God and toward his fellowmen. Nanding offers his talent to God through his participation in the choir but his return to the same group signifies his transformation back to his simple and sincere self, re-establishing his ties with the community he lives in. And like a devout Catholic, he finds answers to problems in the very church where he serves.

Sarung Banggi is an example of a sarswela film that shows the expressions of the Hispanic period, practiced traditions and folksongs, as well as appropriations from the American colonizers creating as a result, an imaginary that exhibits the dichotomy of the lungsod at nayon, and the concept of loob.

\section{MUTYA NG PASIG (1950)6}

Mutya ng Pasig is based on the kundiman written by Deogracias A. Rosario with music by Nicanor Abelardo. This was produced by LVN Pictures with Richard Abelardo directing. The story was written by Mar S. Torres and the music by Francisco Buencamino, Sr. and Francisco Buencamino, Jr.

The river nymph's mortal life is filled with adversities. Despite being a muse or mutya and having a talent in singing, Chedeng (Mercedes) is not as lucky in terms of relationships and family life. She is set to marry Delfin but the latter is arrested, wrongly accused of being a robber. Upon the prodding of his uncle, Chedeng marries Don Modesto, the community doctor who has been courting her for some time. Months later, Delfin innocent of the charges is released from jail. A brief meeting of the two becomes a sour turning point in the relationship of Chedeng and Modesto as Matilde, the long-time helper who is attracted to Modesto, accuses Chedeng of having an extra-marital affair with Delfin. Modesto drives Chedeng and her baby out of his house. She runs unrelentlessly and dives into the Pasig River to 
avoid Modesto's attacking dog. Unfortunately, she drowns while the baby survives.

The baby is found alive floating on top of water lilies by a couple, Angge and Tolindoy, who become the step-parents of Chedeng's baby daughter. They name the baby Mutya and is eventually christened as Consuelo. This young lady joins her parents move around town to sell vinegar. In a particular scene, Consuelo meets the son of Modesto, Basilio, who is playing the violin. Consuelo who sings well is attracted to him and a bond is developed between the two. Like her real mother Chedeng two decades earlier, Consuelo is proclaimed Mutya ng Pasig in their town. On her coronation night, she walks out because her drunk step-father creates a scene. Consuelo rides a banca, loses control, and drowns. The river nymph Chedeng (her real mother) saves her and disappears before anyone could locate Consuelo. Basilio finds her lying along the banks of the river and takes her to Don Modesto who at first refused to give aid. Modesto, seeing a birthmark on her shoulders that points to their biological connection, applies medical treatment on the young lady. In the final scene, Consuelo sings the last part of Mutya ng Pasig accompanied by Basilio's orchestra as Tolindoy, Angge, and Don Modesto proudly sit with the audience and watch her perform.

The film is a kundiman melodrama with a hefty sprinkling of comic scenes provided by Tolindoy.

Chedeng, a talented and beautiful lady, the mutya ng Pasig, is driven out of her home because of a false accusation. This part of the film's story is found in the third part of the kundiman which says (see notation 4):

Notation 4

Excerpt from "Santa Lucia"

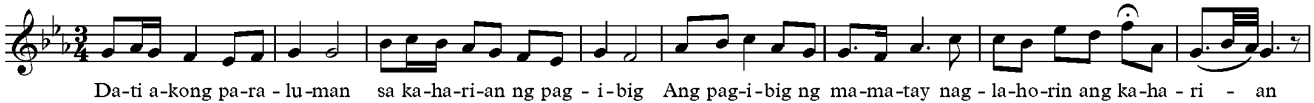

Dati akong Paraluman

Sa kaharian ng pag-ibig

Ang pag-ibig ng namatay

Naglaho rin ang kaharian 
It is sung by Chedeng as Modesto is about to enter her room to force her and her baby to leave his house. This leads to Chedeng's death by drowning in the river Pasig, leading to her "new life" as a river nymph. The earthly life of Chedeng continues in the life of her daughter Consuelo. The union of hearts between Chedeng and Delfin, becomes a reality at the end of the narrative when Consuelo, daughter of Chedeng, and Basilio, son of Delfin, end up as a couple.

There are several songs featured in the film. Angge and Tolindoy sing "Santa Lucia" as they traverse the Pasig River establishing an extra-opus association with the picturesque waterfront district of Borgo Santa Lucia in the Bay of Naples. An invitation of a boatman entices the couple to ride on his boat to enjoy the cool breeze (see notation 5).

\section{Notation 5}

Excerpt from "Santa Lucia"

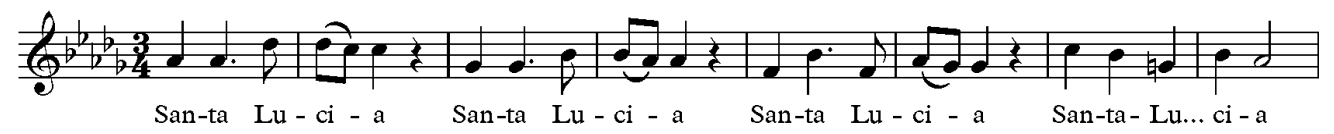

In another scene, Chedeng together with other women doing their laundry (labanderas) at the riverbank sings an ode to the river, "Parang Bangka Lang sa Tubig." The song is in triple time and is a metaphor to love (see notation 6).

Notation 6

Excerpt from "Parang Bangka Lang sa Tubig"

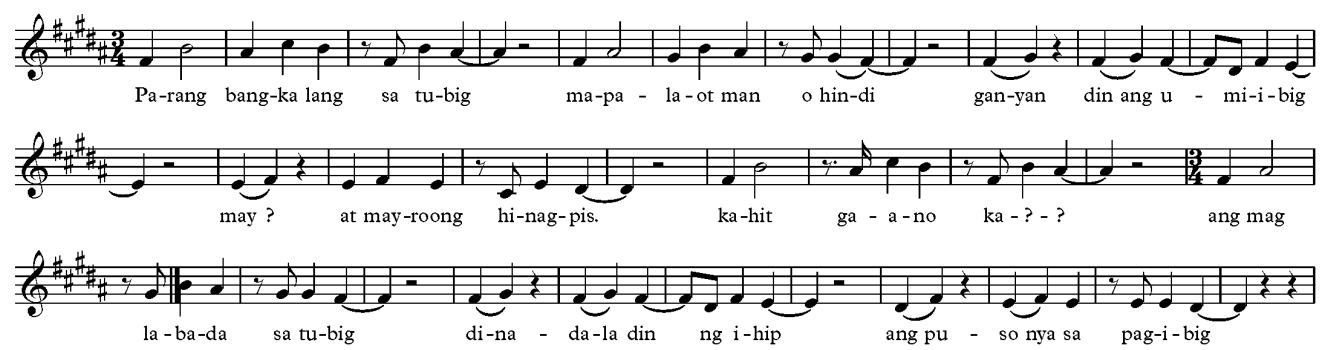


Mutya $n g$ Pasig is a sarswela film and its narrative expresses the concept of awa at pag-asa. Music in the narrative is mainly folk which aurally describes the pastoral scenes. Just as the melody faithfully follows the nuances of the kundiman text, the music in the film brings out effectively the feel of the rural setting and the bucolic way of life.

Chedeng dies as a result of the dictates of her fate. Despite the end to her life, she continues to be part of the narrative through her daughter Consuelo. Her death paves the way for the attainment of love for all, sacrifice, and redemption, expressing the extra-musical meaning of the kundiman. Likewise, Don Modesto faces several afflictions in life such as his being a second choice of Chedeng as husband, giving in to an accusation that leads to his wife's death and loss of his daughter, having paralysis due to his hardened soul, and retreating from the world into his own desolation. The two characters whose lives are shaped by the consequences they encounter individually are Chedeng with her goodness of intention and Modesto with his distrustful outlook that leaves him isolated.

The concept of loob which is contrasted in the two characters is explained by Albert Alejo, S.J., in the Filipino language: “... na ang salitang "loob" ay ginagamit sa isang holistikong paraan, tumutukoy ito sa malawak na katotohanan ng tao at sa umiiral niyang pakikipag-ugnayan sa sarili at iba" (21).

The dichotomy of the inner-self of Chedeng and Modesto is instrumental in telling the narrative of Mutya ng Pasig. The film expresses the concept of loob through Modesto who after rejecting his wife goes through depression. With introspection, he is re-united with his biological daughter symbolizing reconciliation with Chedeng, Consuelo, and his own self. Chedeng who suffers rejection and death, continues to exist in the person of Consuelo. Mortality to immortality, her life experience is an expression of loob.

\section{MAALA-ALA MO KAYA (1954)}

Maala-ala Mo Kaya, the danza by Constancio de Guzman, was made into film in 1954, 1973, and in 1994. The TV series of the same title began in 1991 and is still running up to the present. The 1954 film was produced by LVN Pictures and directed by Mar S. Torres. The story, adopted from the Bulaklak and Aliwan magazine serial, was written by Fausto J. Galauran. Music is by Ariston Avelino, one of the prominent film musicians during the era. 


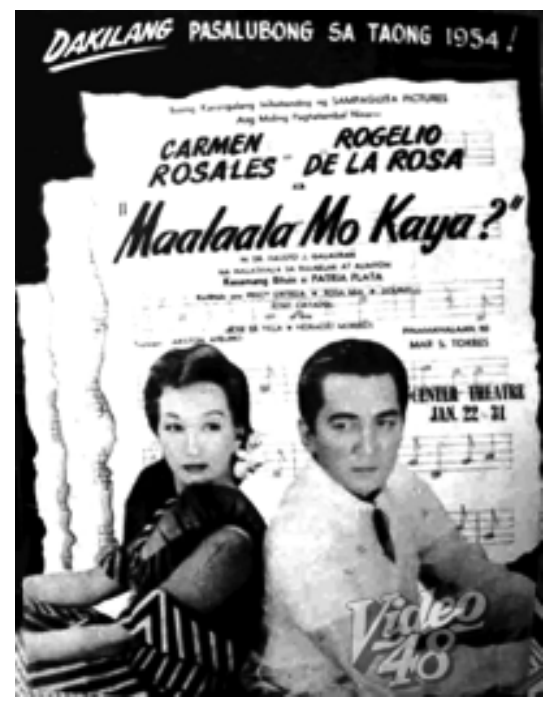

Fig. 4 "Maala-ala Mo Kaya" promotional poster. Center Theater. 1954. Reprinted by permission of Simon Santos.

The film narrative is a kundiman melodrama, a term I have conceived to identify a Tagalog or Filipino melodrama film where the kundiman's extra-musical meaning of mercy and hope (awa at pag-asa) signified through its melodic character and text, is rooted in the film's story. The kundiman melodrama articulates pain, sorrow, perseverance, deliverance, and hope, through the character/s' and the film's story. This kind of film is usually based on a popular song, and would have the song's title as its own. The word melodrama comes from the Greek word melos meaning "music" and from the French word drame or drama.

The film extensively utilizes de Guzman's "Maala-ala Mo Kaya” though in the opening scene, the song "Ang Dalaga sa Bukid" (Scene 1;0:01:18) is heard. The movie extensively uses non-diegetic music together with poetic Tagalog script that creates a feel of listening to a song. Thus, watching this melodrama may be likened to watching a musical film.

The plot revolves around the creation of the song "Maalala mo Kaya" by Celso and Pilar. They exchange their love through beautiful poetic lines set in non-diegetic music in Scene 7 (00:17:41): 
Celso:

Manalig ka, makaka-asa ka sa dala kong pangako

Sapagkat ang bawat tibok ng ating mga puso at tutuhugin ng aking katapatan

Gagawin natin ang isang magandang kwintas na ala-ala

Ala-alang magiging buklod $n$ gating pag-iibigan

Pilar:

Siya nga! At kung dumating ang dapit-hapon

Ang kwintas na ala-alang iyan

Ay iaalay natin sa paanan ng Maykapal

Upang pagpalain ang ating pag-ibig, hanggang sa kabilang buhay

Celso:

Bawat sandali sa iyong piling ay kapantay ng kaligayahan

Pilar:

At kung tapos na ang mga sandaling ito, at kung tayo'y magkakalayo na

Maalala mo pa ba kaya ako? Kagaya dati?

Celso:

Paano kita malilimot? Habang buhay ay maala-ala kita!

The film progresses with Pilar encouraging Celso to offer his song to record companies in Manila. Celso takes his luck and proceeds to Manila where he meets Patria del Mar, a record company executive, who eventually falls for Celso. Pilar is informed of Patria's efforts to win the heart of Celso. Despite the unfortunate twist, Pilar does not seek explanation and accepts fate as she perceives it (Scene 12; 0:44:48):

Iniibig ko sya, at kasama ng aking pag-ibig ang kanyang tagumpay.

Ang kabiguan ay para sa akin, hindi para sa kanya.

Talagang ganyan ang buhay, kung may tuwa'y may kalungkutan...

Kung masasabing napakasakit ang gawang limutin

Para sa akin ay napakasarap naman ang gawing magpatawad. 
Pilar moves on from her relationship with Celso and pretends that she will marry Enrique, but the truth of the matter is Pilar loves Celso very much that she opts to let him decide freely (Scene 16; 0:53:05):

Patawarin mo ako, pinatawad din kita

Nakilala ko, kamalian ang ibigin kita

Hindi ikaw, hindi ikaw ang lalaking magpapaligaya sa akin

Wala sa iyong puso, dinadakila ko sa isang lalaki

Sumama ako kay Enrique sapagkat sa kanyang pag-ibig ay muli akong nabuhay upang limutin ka...8

The narrative takes a turn for the worse when Patria, in a rage, shoots herself. This incident brings a series of court hearings against Celso. Meanwhile, Precy the daughter of Celso, begins to take piano lessons and by a twist of fate, takes it under Pilar. The court acquits Celso and this begins the healing of Pilar and Celso's soured relationship.

Through the song Maala-ala Mo Kaya that Pilar and Celso composed together, Precy is able to reunite her father with Pilar. Celso in the final scene of the narrative (Scene $43 ; 2: 08: 01$ ) says:

Huwag kang lumuha

Sa buhay ng tao'y hindi dapat manatili ang kalungkutan

Ang bawat patak ng luha mo Pilar

Ay may katumbas na kaluwalhatian

Limutin natin ang nakaraan

Harapin natin ang ating kinabukasan na buo ang taing mga loob

Sapagkat naroroon ang ating pagasa

Ang ating bagong langit

This scene shows Precy performing "Maala-ala Mo Kaya" in a piano recital. Celso stands nervously at the right wing of the stage while Pilar, anxious and nervous, sits in the audience area. Pilar decides to go backstage to give her student her support, and unknowingly stands beside Celso. Precy finishes her performance successfully with the 
presence of the two important persons in her life. The scene is the film's denouement.

The extra-musical awa at pag-asa is personified through Pilar. Pilar accepts what is not meant to be and begins to introspect and find herself unworthy. Self-pity sets in as she pretends to marry another man despite her deep love for Celso. All turn to hope with a re-connection through Precy.

The narrative also presents the dyad of lungsod at nayon. Expressions of love and beautiful music are central in scenes of the countryside. The plot turns sour when Celso reaches Manila. It is in the city where Celso is lured by Patria with money and fame in exchange for love. They marry and live together but events eventually turn dark leading to the fatal self-inflicted gunshot by Patria. Hope springs back as Celso and Pilar reunite in the nayon.

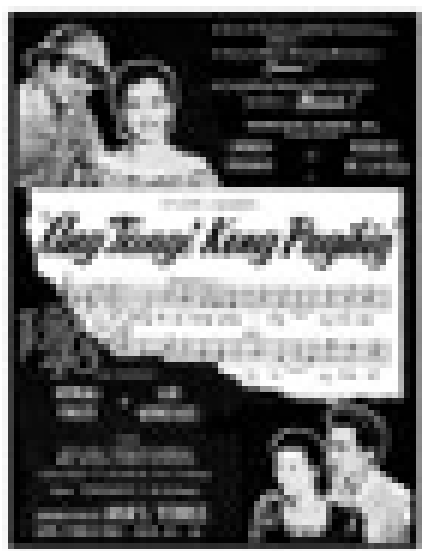

Fig. 5 "Ang Tangi Kong Pag-ibig" promotional poster in Life Theater. 1955. Reprinted by permission of Simon Santos

\section{ANG TANGI KONG PAG-IBIG (1955)}

Ang Tangi Kong Pag-ibig, produced by Sampaguita Pictures in 1955, is one of the films that launched the love team of Carmen Rosales and Rogelio dela Rosa. The film was directed by Mar. S. Torres, with screenplay by Fausto J. Galura and Conrado Conde. The song Ang Tangi Kong Pag-ibig was composed by Constancio de Guzman who musically directed the film. 
Ang Tangi Kong Pag-ibig (1955) is one of the films re-produced by Sampaguita Pictures after a fire gutted its film storage in $1950 .{ }^{9}$ It is an example of a kundiman melodrama. The film shows the extra-musical quality of awa at pag-asa embodied in the character of Jovita del Prado, a beautiful and talented singer, who despite her success decides to leave the city for a peaceful life in the nayon.

In the opening scene, Jovita decides to end speculations about her alleged relationship with the club owner and leaves her singing career behind to return to her hometown.

From Scene 1; 0:07:29:

Bakit ko ba sila iintindihin? Wala silang pakialam kung ano ang gusto kong gawin sa buhay ko. Ngayong gabi tatapusin ko lahat ng sinasabi nila tungkol sa akin Hindi ko kailangan ng pag-hanga na may halong pagkutya sa akin.

Ang tagumpay na ito ay nagbigay bahid sa aking pangalan.

Ingkong and Osang warmly welcome back Jovita. She then informs her Ingkong and sibling that she intends to stay in their house for good. It was an opportunity for Jovita to apologize for having left their house a few years ago. The scene is a pagbabalik-loob for herself and her family.

From Scene 5; 0:12:10:

Patawarin mo ako Inkong ngayon ko nakilala ang aking pagkakakamali. Mula ngayon ay ilalaan ko na lang ang aking buhay sa paninilbihan sa inyo at kay Osang.

Jovita enjoys the nayon environ and sings "Pagsapit ng Umaga sa Atin," a song that expresses the contrast of countryside and city. Moving around the neigborhood a dog, owned by a landlord (haciendero) Sergio Laxamana, bites her. Jovita gets to know more about Sergio as he accompanies her to get her shots from the nunnery within Sergio's hacienda. They both discover a commonality-their preference for the peaceful countryside life. The couple fall in love with each other but Jovita finds herself unworthy.

From Scene 15; 0:47:55: 
Jovita:

Kailangang magkalayo kami ni Sergio...sapagkat hindi na ako maaring magkaila, iniibig ko siya ngunit nalalaman kong kong hindi ako nababagay sa kanya.

Kayat habang maaga mabuitn pang layuan ko na sya... sa kumbento ng mga madre, ipakikiusap kong itago nila ako dun at kahit magsilbi ako ng walang bayad, maiwasan ko lang siya.

Despite Jovita's uncertainties, she finds happiness with Sergio. There is affirmation of reciprocal love.

From Scene 16; 0:50:25:

Sergio:

Nawala na sa akin ang pagaalinlangan at naging panatag na ang aking pag-iisip

Ang wagas kong hangad ay mapaligaya kita ay maialay sa iyo ang isang makulay na daigdig

Hindi na kailangan yan sapagkat ikaw lamang ang makapagbibigay sa akin ng kaligayahan

Ikaw at ang iyong banal na pag-ibig. Sapagkat nariyan ang aking buhay, ang aking pag-asa, ang tangi kong pag-ibig

Sergio is the town's fiesta hermano, being the son of the late Osinando Laxamana who initiated the annual fiesta celebration. In this annual festivity, he formally introduces Jovita to the community as she sings "Ang Tangi Kong Pag-ibig." After the performance, Luis, the first cousin (primo) of Sergio announces the engagement of Sergio and Jovita.

Meanwhile, the club owner in his rage over Jovita's leaving her job, exerts all efforts to locate her. He eventually reaches the house of Jovita and demands to see her. At this time, preparations for the wedding are being done. Jovita, about to leave the house for her church wedding, finds herself face to face with the club owner who then abducts Jovita.

Jovita: “Anong kailangan mo?"

Club owner: "Ikaw! Sinusundo na kita." 
The club owner carries Jovita on his shoulder and takes her away. A fistfight ensues between the men of the club owner and some townfolks. Osang calls Luis and Sergio. The good guys prevail in the end but Jovita now finds herself more confused and runs away.

Jovita:

Sa nangyaring ito'y hindi na ako maaring pang humarap pa kay Sergio.

Sergio and Luis begin an extensive search for Jovita and in one of their trips, they figure in a car accident. Sergio's eyes are affected and he is confined in a hospital run by nuns. This is the same convent/hospital which Jovita eventually enters and as a novice, she is given the religious name "Sor Cecilia."

In Scene 31; 1:35:25, Sor Cecilia enters a room where she unexpectedly finds Sergio as the patient. She utters: "Dios ko lakasan nyo ang loob ko." Sergio, with an eye bandage, thinks that it was Luis who entered the room. Sergio asks: "Luis, Luis, nakita mo ba sya? Kailangan ko sya."

In one of the routinary rounds of Sor Cecilia, Sergio realizes that he and Jovita are together in the same room. Sergio pleads with Sor Cecilia to listen to him while she requests Sergio to respect her as a religious. Jovita explains that her decision to enter the convent is the way to redeem herself from her past mistakes. In Scene 35, Sergio's eye bandage is taken off and sees Sor Cecilia again after a long period. Sergio insists that they talk but Sor Cecilia refuses and instead she utters:

\section{Salamat sa Diyos at nakakakita ka na}

Ang nakaraan ay nakaraan na at sa aking kaalama'y walang pag-ibig na namagitan sa ating dalawa

Sergio informs Sor Cecilia that he will leave the hospital the next day and hopes that she joins him. Sor Cecilia once again begs that Sergio respects her decision to stay in the convent. Sergio asks what made her change her mind. She replies that she is at fault, her person and her past.

From Scene 38; 1:49:26: 


\section{Sor Cecilia:}

"Utang naloob iwanan mo na akong mag-isa, ngayong magaling ka na at malakas ay maari ka ng umalis, limutin mo na ako."

\section{Sergio:}

"Bakit napakalupit mo naman sa akin Jovita? Bakit hindi mo bigyan ng pagkakataon ang iyong damdamin?” May panahon pa naman Jovita, upang mapigigil ang balak mong yan. Ang nais ko lang malaman ay ipagtapat mo sa aking kung ano ang pagkakasalang nagawa ko sa iyo upang akong palayuan mo at pasakitan ng ganito."

\section{Sor Cecilia:}

"Wala kang kasalanan, ako ang dapat mong sisihin. Ako'y hindi nararapat sa iyong kadakilaan...ako at ang aking kahapon."

The Mother Superior observing the events talks to Sor Cecilia and assures her that she can still serve the Lord even without the nun's habit. She advises Sor Cecilia to return to Sergio and live a happy secular life: "Jovita ang pagsilbi sa Diyos ay hindi lamang sa kasuotang yan... magbihis ka at bumalik ka sa kanya."

In the final scene, Jovita donned in plain clothes leaves the monastery with the Mother Superior accompanying her while Sergio waits at the gate. Jovita walks through the gate and Sergio takes her into his embrace.

\section{Pawiin mo iyang mga luha mo Jovita}

Ang iyong nakaraan ay hindi maaring humadlang sa ating pagmamahalan Sapagkat... ikaw lamang ang tangi kong pag-ibig

Ikaw lamang ang aking mamahalin habang ako ay nabubuhay....

Jovita's dialogue in the narrative specifically in Scenes 1, 15, 23, 35, and 38 shows her feeling of unworthiness despite her introspection and decision to make up for the past. This is the kundiman's awa. Hope (pag-asa) comes in at the last part when Mother Superior advises her to serve the Lord outside the walls of the convent. With the perseverance of Sergio in expressing how important Jovita is in his life, she finally comes to terms with herself and starts life anew. 
The song "Ang Tangi Kong Pag-ibig" creates a linearity schema that runs parallel to the narrative. It expresses an imaginary at the level of the narrative as it portrays awa at pag-asa of the kundiman and loob. The film expresses a selfless, deep devotional love to a point that is spiritual, embodying the spirit of the kundiman.

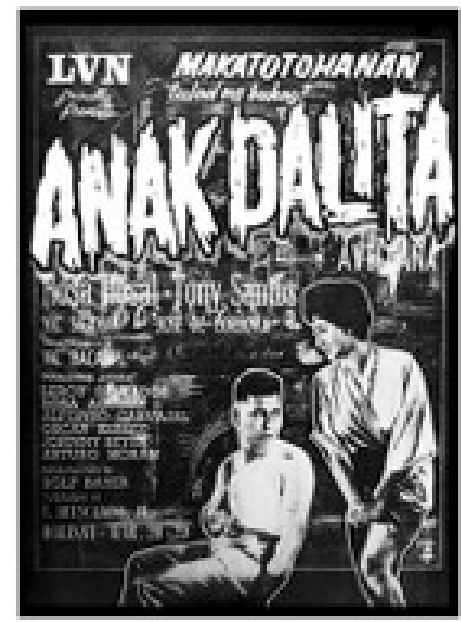

Fig. 6 Promotional poster of the film "Anak Dalita." 1956. Reprinted by permission of Simon Santos.

\section{ANAK DALITA (The Ruins) (1956)}

Anak Dalita, produced by LVN Pictures in 1956, won as Best Film in the Asia Pacific Film Festival of 1956, and the International Prestige Award of Merit in 1958 given by the Filipino Academy of Movie Arts and Sciences (FAMAS). The film was directed by National Artist Lamberto V. Avellana with music ably provided by Francisco Buencamino, Jr. and Restie Umali. The kundiman "Anak Dalita” was composed by Francisco Santiago based on the text written by Deogracias Rosario. The cast is led by Rosa Rosal, Tony Santos, Jose Cordova, and Vic Silayan.

The first verse of "Anak Dalita" gives the message that the film wants to impart (see notation 7): 
Notation 7

Excerpt from "Anak Dalita"

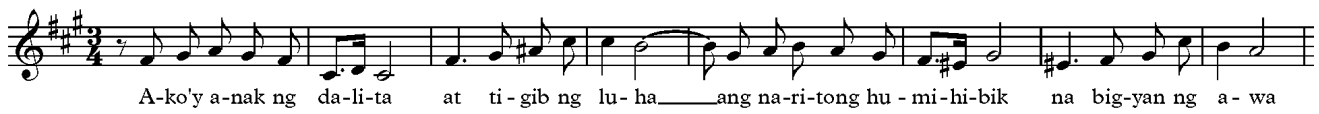

The kundiman "Anak Dalita" was composed in 1917 by Francisco Santiago. A film with the same title (non-extant film) was produced by Jose Nepomuceno in 1936. Twenty years later, Anak Dalita was directed by National Artist for Film, Lamberto Avellana, and was produced by LVN Pictures.

Anak Dalita is a kundiman melodrama that focuses on destitution. The film is not the usual fare film producer Doña Sisang Buencamino-de Leon would offer to the audience of LVN Pictures. The film was produced with hesitation by the lady producer who believed that this genre would not sell. Though it is a landmark film due to its numerous awards, true to Doña Sisang's presumption, the film did not do well in the box office.

Anak Dalita was released in 1956, eleven years after the Liberation of Manila. The teaser placed above the film's promotional poster which says "Makatotohanan tulad ng buhay" reflects the state of the nation, that is, it has not risen from the ashes of war.

The scenes are set within the confines of the bombed ruins of the Recolletos Church in Intramuros where informal settlers had claimed areas within the church perimeter as their own. The choice of the church ruins as location signifies the local people's spirituality as it gives temporary solace while facing the harsh realities of life. Jose de Mesa's concept of loob as two-pronged is exhibited in the said scenes.

Within the ruins is a community of diverse people, all of whom are victims of the past war. Tita works as a club dancer and is an object of rumors within the church walls. She is a sensitive, strong-willed person capable of doing the unimaginable to save the man of her affection. She walks tall within the community despite being looked down upon because of her profession.

In the narrative, she helps a "fallen" soldier with whom she shares her meager resources. Vic, a war hero from Korea, comes home with a medal for bravery and service. Desolate over the death of his mother coupled with his 
condition in life, he searches for the reason of his existence. He realizes that being a war hero cannot make life better. In as much as he values his achievement, he now sees it is not enough for him to live a decent life.

Tita offers her place to Vic. Having no other recourse, he accepts the proposal. The next scenes present conflicts as the stoic and desolate Vic deals with the strong- willed Tita. Vic physically hurts Tita in their domestic conflicts yet she forgives him for such actions. Vic's violent episodes shows his desperation over the fact that he has become unproductive due to his paralyzed right arm. Vic was a sculptor and now handicapped due to the accident. But with determination, he learns how to sculpt again with his functioning left arm and to overcome his disability.

When Vic is offered by a friend to carry out an illegal job by smuggling cash out of the country, he accedes to the offer but is saved by Tita from being arrested before he places himself in a precarious situation.

Fr. Fidel, the community pastor, prepares his community for the eventual eviction of the informal settlers from the church compound in order to restore the house of God. He balances compassion for his flock with a reminder of their responsibilities as citizens. A ray of hope is seen in the final scene where Fr. Fidel leads the community out of the ruins. They leave to relocate elsewhere where they can re-establish their homes and hopefully live a fuller life. Tita and Vic are the last people to leave the ruins, symbolic of the motherland and its soldier starting anew and hoping to live life in the right direction. There is hope after asking for mercy. There is redemption after the sacrifice:

Sa dilim ng gabing aking nilalamay

Tanging larawan mo ang nagiging ilaw

Kung ikaw ay mahimbing sa gitna ng dilim

Ay iyong ihulog puso mo sa akin

Ang iyong ihulog, ang iyong ihulog

Buhay, pag-asa, pag-asa!

Loob is expressed as the community willingly moves out of the ruins to start a better life. The action symbolizes kagandahang loob and their openness for rectification, illustrating Reynaldo Ileto's concept that loob connects itself 
to the physical environment and becomes a reflection of it (Alejo 23). An underprivileged community affected by the war goes through the trials of life and eventually faces a new challenge of expecting and hoping for a better life after the ruins.

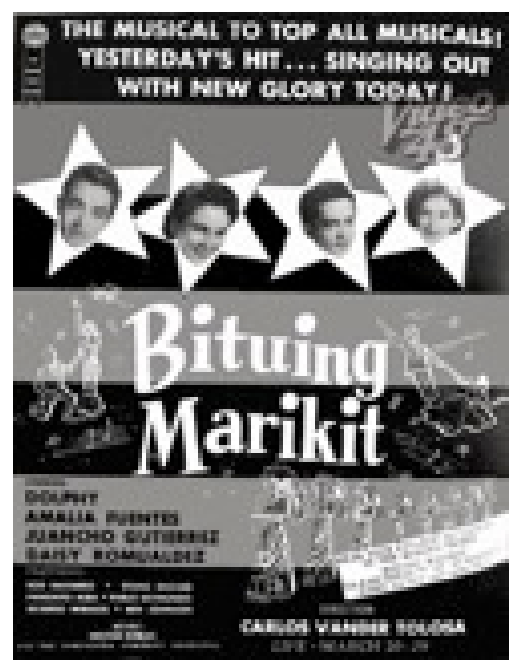

Fig. 7 Film promotional poster of the 1937 non-extant Bituing Marikit which was burned in a fire that hit the bodega of Sampaguita Pictures. This film was the inspiration for the 1957 remake of the film which was still directed by Carlos Vander Tolosa. Reprinted with permission from Simon Santos.

\section{BITUING MARIKIT (1957)}

In an interview with Dr. Michael Coroza, mention was made that one of the reasons why there is a dearth of extant pre-war Filipino films is because of a fire that razed the bodega of Sampaguita Pictures in 1950. After the incident, realizing that they have lost their history, Sampaguita Pictures decided to do remakes of their memorable films. Among those was Bituing Marikit which was the inaugural production of Sampaguita Pictures in 1937. Carlos Vander Tolosa and Luis F. Nolasco, the director and writer respectively were part of the original production. The 1937 version had a different set of musical directors namely Jose A. Estella, Juan Silos Jr., and Miguel 
Velarde Jr. while that of the 1957 version had Nestor Robles. The featured songs are similar: Bituing Marikit, Dahil Sa Iyo, Ay Kalisud, Sa Kabukiran, and many others. It is interesting to note that in the poster of the 1957 re-make, the promotional tagline was "hear your favorite kundiman in the modern tempo.”

There is a different set of actors and actresses for the two versions. The 1937 version featured Elsa Oria, the "Singing Sweetheart of the Philippines," Sylvia Rosales, Rogelio dela Rosa, and Ely Ramos. The 1957 cast was composed of Amalia Fuentes, Juancho Gutierrez, Daisy Romualdez, and Dolphy.

The main consideration why this film was included in this study is to have more or less a postulation of another pre-war musical film which the writer deems essential as there are only five extant pre-war Filipino films. Considering that the 1937 Bituing Marikit marked the inauguration of Sampaguita Pictures, this film version is highly significant.

Bituing Marikit is an appropriated sarswela film as it takes on a modern twist in presenting the songs through production numbers similar to musical theater. Sa Kabukiran is sung with choreography by ladies with umbrellas as part of their costumes adding color to the scene (Scene 2; 0:02:50). The lofty and soulful kundiman Bituing Marikit is performed fast to which Cosme performs a tap dance (Scene 19; 1:09:35). The song Dahil Sa Iyo by Mike Velarde is sung with a female trio doing "barbershop" harmony (Scene 3; 0:08:42). A harana entitled Pag-ibig Ko'y Ikaw sung by Mario is backed up by a rondalla and a string orchestra (Scene 5; 0:18:27). All the above-mentioned songs are traditional Tagalog folk appropriated to entice the viewing public who may want something new and modern.

The narrative opens with Mario and Cosme watching Estrella sing Sa Kabukiran. The scenes that follow are a series of production numbers: Mario renders a harana with a rondalla and a string orchestra; Cosme does another harana with Mario; a radio contest where Cosme sings a medley of Filipino songs and appropriated American Rock and Roll; Estrella's birthday celebration complete with an orchestra and dancers; and a finale wedding scene with all the featured song reprised. The film mimics a sarswela with its simple story with dialogue and sub-plots that lead to a song and/or dance number. The film features a mix of Tagalog and American music. 
This second version of Sampaguita Picture's production of Bituing Marikit exhibits the cultural changes after the war specifically the strong influence and acceptance of the Tagalog toward American influences. Here we see the people's response to colonial experience-holding on to traditional culture in the midst of changes in the name of progress. The film as a whole shows lungsod at nayon not in its storyline but in the manner by which musical and dance traditions are presented. Some may consider the film as purely commercial devoid of identity and values. This film reflects a part of Philippine history and the response of generations of Filipinos to the changing times. Despite strong colonial influences, the Tagalog keeps his spirit and being, a manisfestation of the consciousness that will never change, through change.

\section{KUNDIMAN NG LAHI (1959)}

Kundiman ng Lahi was produced by LVN Pictures in 1959. The film was directed by National Artist Lamberto Avellana with music by Francisco Buencamino, Jr., and Restie Umali. It is to be noted that the music of this film, similar to that of earlier Filipino films, was recorded by a live orchestra. LVN Pictures had a resident orchestra, the LVN Symphony Orchestra, showing the production outfit's priority and importance given to a film's musical element despite this film's drama genre.

The film opens with a new approach to music scoring. Instead of the usual folk or western-influenced melody, the bamboo stamping tube called tongatong plays in sync with the scene's rice pounding. The tongatong bamboo music then segues to Sa Gawaing Bukid ${ }^{10}$ which opens the narrative showing a community fiesta and the townfolk's palay harvesting. The melody of $\mathrm{Sa}$ Gawaing Bukid is folk and light in character but the lyrics of the song are sober (see notation 8 ):

From Scene 2; 0:01:50:

Sa gawaing bukid tayo'y magsikap

Sa tulong ng bisig tayo'y uunlad

Sa tulo ng pawis ay maliligtas

Ang lahi nating tunay na naghihirap 
Notation 8

From "Sa Gawaing Bukid"

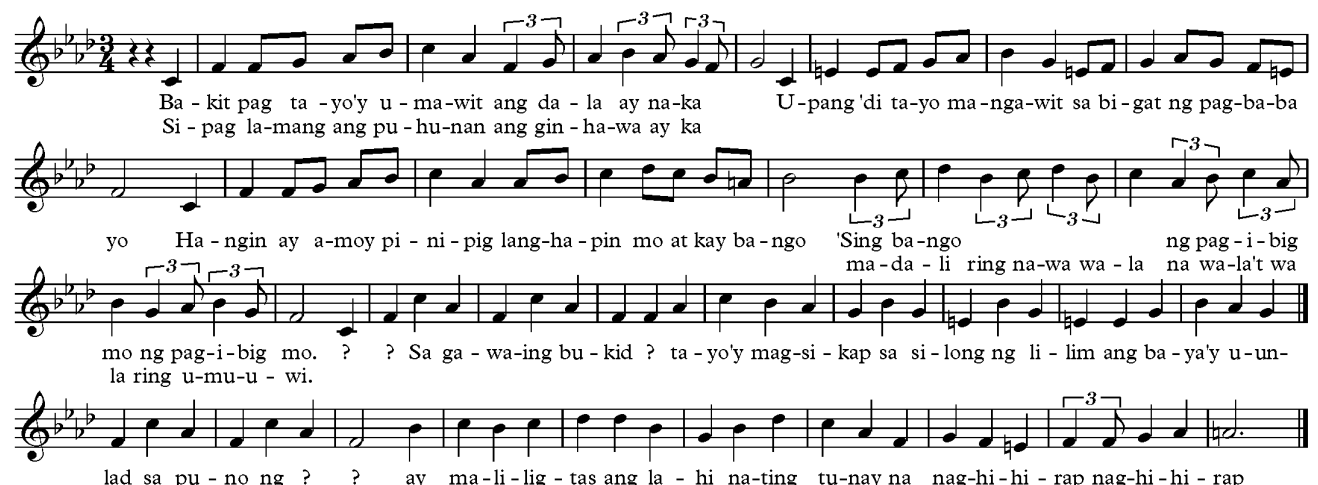

The film has a semi-diegetic speech ${ }^{11}$ narration done by Isang who shares her travails and thoughts as she goes through the hardships of life. In Scene 4, Isang narrates the happenings in their household after the death of her mother. She also tells of the treatment she gets from her aunt/fostermother including the sexual desires of her step-uncle/foster-father, Teryo.

Isang:

Iba ang pagtingin sa akin ni Tia Siyanang

Nagkaroon ako ng pangamba

Hindi naman ako tunay na pamangkin ni Tio Teryo

Paano ko maipagtatapat kay Tia Siyanang ang bagay na ito sa kanya?

Tonyo pursues Isang but Siyanang and Teryo does not want him paired with her. In Scene 5; 0:12:06, Tonyo approaches Isang while she washes clothes by the stream. Their dialogue turns poetic with Kundiman ng Luha played on guitar non-diegetically.

Tonyo:

Ang ibig sabihin ba niyan ay ang aking binhing ipinunla

Sa pamamagitan ng tiaga ay nakatagpo rin ng lupang maawain?

Upang sa darating na araw ay Ako'y aani ng masagana 
Isang:

Ang lupang tatamnan ay laging nariyan

Marahil ang manananim ay salat sa pag-iingat

Nagtanim ng pasabog, wala pa sa loob, kulang pa sa panahon

Ang manananim na iyan ay ngayon lang kung sakali'y nag-punla

Siya'y nagatubili, nangamba

$\mathrm{Na}$ baka sakali na sa tayog ng kanyang pagnanais

Ay wala siyang makamtan kundi pagkabigo

Ang taong may ninanais ay dapat matapat

Huwag siyang maiinip, dapat tiyagain

Sapagkat maaring sinusubukan lamang siya.

In Scene 9; 0:23:25, Isang describes the effort she puts into her work to be able to pay for the arrears that her mother left:

At halos ang gabi, gawin kong araw

Upang kumita ng salapi pambayad sa mga utang na iniwan ni Inang

Higit sa lahat, ang pagtubos sa naka-sanla naming lupa

Her foster parents, Teryo and Siyanang, urge Isang to work in the cabaret to earn more money. Isang initially rejects the plan as she does not see herself doing such a job but eventually, out of fear and frustration, she voluntarily enters the cabaret as a baylarina.

Tonyo proposes marriage to Isang which she accepts. They support themselves with Tonyo's meager salary from a mining firm while Isang does household chores. Marital problems arise when a co-worker of Tonyo recognizes Isang as one of the baylarinas who worked in a cabaret. The issues and misunderstandings are resolved through dialogues. Towards the film's denoument, Isang's experience of being molested by Teryo is revealed to an unbelieving Siyanang until Teryo, on his deathbed, asks forgiveness for his sins. The narrative ends with Tonyo returning to Isang together with Siyanang helping out the couple. Isang's narration ends the film with the following lines from Scene 39; 1:39:42: 
At sa wakas

Ng mahawi ang ulap,

nagtagumpay rin ang pagtitiis

Ang katapatan ng sumpaan

Ang dalisay na pag-ibig ng babaeng Pilipina

Ang dangal ng lahing kayumanggi!

The film's title Kundiman ng Lahi is taken from the song Kundiman ng Luha composed in 1924 by Nicanor Abelardo with lyrics by Jose Corazon de Jesus. The song has an extra-opus association that establishes the period of the film. It depicts the sorrow of a person who after experiencing joy grieves alone because of unforeseen misfortune (Kundiman ng Luha):

Kundiman ng Luha

Paraluman sa pinto ng iyong dibdib

Isang puso ang naritong humihibik

Kaluluwang luksang-luksa at may sakit

Pagbuksan mo't damayan kahit saglit

Tingni yaring matang luha'y bumubukal

At humihingi ng awa mo't pagmamahal

Damhin mo rin ang dibdib kong namamanglaw

Yaring puso sa pagsinta'y mamamatay ay!

Ilaglag mo ang panyo mong may pabango

Papahiran ko ang luha ng puso ko

Ah pag-ibig, kung ang oo mo ay matamo

Ah pag-ibig kung ang oo mo ay matamo

Hanggang sa hukay

Hanggang sa hukay

Magkasama ikaw at ako

Magkasama ikaw at ako!

This kundiman is played on guitar and heard without text diegetically and non-diegetically. The guitar's soft timbre impresses the delicate 
character of Isang amidst the turmoil of her environment. ${ }^{12}$ The music of Buencamino holds to the rather "dark" film character from beginning to end. This provides a calm and subdued atmosphere effectively contributing to the color of the narrative. The film has strong undertones about gender and nationhood. As Vicente Rafael states: "Women personify the beloved nation waiting to be rescued; yet they also generate the conditions that make their rescue both possible and desirable" (49). This is the narrative's course while relaying the story of Isang.

In the first part of the film, conditions are beyond Isang's control. The steps and actions taken by Isang paved the way for her eventual redemption. The last semi-diegetic speech of Isang refers to the female Tagalog (Tagala) as "ang dangal ng lahing kayumanggi." The film Kundiman ng Lahi is a kundiman melodrama signifying mercy and sacrifice leading to hope and redemption for Isang, and for what she stands for, the motherland.

\section{Notes}

1. The film copy has missing scenes and some speaking and music parts are incomprehensible.

2. A danza is a song in quadruple time taking its roots from a social dance which is of Cuban origin. It is believed to have gained popularity in the Philippines through the sarswela.

3. Non-diegetic music is music in a film used outside of the story space. This is commonly referred to as background music.

4. The condition of the film can be described in the following ways: several scenes have abrupt cuts, which makes it difficult to focus on certain lyrics of songs; sound also suffers as some dialogue and songs are near incomprehensible; and some scenes have turned so dark that it is hard to see what is happening in the scene/s.

5. This attire is standard wear for a landlord (haciendero).

6. The film is based on the musical composition Mutya ng Pasig by Nicanor Abelardo as serialized in Sinag-Tala by Mar S. Torres.

7. This is the monologue of Pilar in Scene xii.

8. This is the monologue of Pilar in Scene xvi.

9. This is according to Tia Dely, a radio personality, as revealed in an interview 
I conducted with Dr. Michael Coroza. But doing some cross-checking with the Internet Movie Database (www.imdb.com), a reliable site for film information, and other Filipino film blog sites, it appears that there is no movie of the same title produced by Sampaguita Pictures before 1950. Just the same, the writer included the film in this study.

10. The title is taken from the first line of the chorus.

11. A voice-over commentary is provided by one of the characters of the narrative.

12. This is an "analogy association" based on musical elements to bring out meanings. 


\section{Summary}

This study on music in films provides an understanding of the many ways by which an imaginary can be expressed. Among the Tagalog, the concepts of loob, awa at pag-asa, and lungsod at nayon are vital in the creation of the Tagalog imaginary. In film, folk customs and folk music transport viewers in communion back in time. The concept of awa at pag-asa, an extra-musical meaning of the kundiman, is expressed through its film characters and narrative. The kundiman melodrama characters plead for mercy that springs from within the loob. For example, Jovita in Ang Tangi Kong Pag-ibig, Vic and Tita in Anak Dalita, and Isang in Kundiman ng Lahi all personify awa at pag-asa in their stories.

The sarswela film creates an imaginary in the nayon signified by local songs, dances, and ways of life. Nayon represents the moral fiber of the Tagalog that withstood modernization and the influence of American culture during the period. ${ }^{1}$ It contrasts with lungsod represented by economic progress and the ills of colonial influence. Michael Coroza says that pureness of one's self, or dalisay na pag-ungali, resides in the people of the countryside, which is fittingly portrayed in the films discussed. In Sarung Banggi, Nanding 
loses his family and friends when he sought fame and fortune in Manila but gained them back upon his return to the nayon. In Ang Tangi Kong Pag-ibig, Jovita, a famous Manila-based singer returns to her hometown to find peace and happiness. The choice of repertoire and instrumentation represents locale and condition. The saxophone and the big band, symbolic of lungsod, are utilized for scenes of nightclubs, entertainment, mundane desires, deceit, and all things temporal. The music of the brass band, rondalla, guitar, musikong bumbong, and indigenous instruments draw aural images of the traditions of the nayon.

The imaginary in kundiman melodramas and sarswela films is expressed through the concept of loob. It is a Tagalog philosophy rooted in local culture, experience, and language that leads to awareness, understanding of the meaning of life, and maturation of self and society. The process fills the void that was created when the "colonizers invaded our space." Nanding in Sarung Banggi experiences rejection but is re-accepted after his introspection. It is his devotion that provides a resolution to misunderstandings. ${ }^{3}$ Modesto admits his sins to Chedeng with contrition. He is reunited with his daughter Consuelo in Mutya ng Pasig. Pilar surrenders to Celso's predicament in Maala-ala Mo Kaya, leading to their separation but they are reunited after undergoing trials that prove their love for each other. In Ang Tangi Kong Pag-ibig, Jovita del Prado, a successful singer, leaves her profession and enters the nunnery to repent for the sins of the past and returns to her community with a clean and positive outlook. ${ }^{4}$ Tio Teryo, in Kundiman $n g$ Lahi, confesses his sins on his deathbed, relieving him of his earthly burden which resulted in the reconciliation of Tonyo and Isang as well as the reconciliation with Siyanang, Isang's aunt.

The celebratory Christmas scenes manifest the devotion of the Tagalog to his faith. Happy denouements in narratives are found in the proclamation as Mutya of Chedeng and Consuelo in Mutya ng Pasig. The return of Nanding as choir singer for the Christmas eve mass, earns him the blessings of Marina's father for their wedding in Sarung Banggi, and the Christmas celebration in the house of Tita's biological parents leads to the unification of the family in Tunay na Ina. The impact of Catholicism in Tagalog culture that articulates religious beliefs brings to mind Jose De Mesa's concept of loob as two-pronged: one directed toward God and the other toward his 
fellowmen. The dual connection of God and man to oneself provides a transformation everybody aspires for. Likewise, the communal spirit of the Tagalog is expressed through religious celebrations. Fiestas and Christmas festivities are community experiences. It is Tagalog bayanihan in action, not only in work but also in celebrating life together as one.

The kundiman and sarswela complement each other through loob in which a significant connection is created. Both cultural genres have become instruments of the inner self, the community, God and man relationship, culture and traditions, and nationhood, creating an imaginary expressive of the Tagalog movie-going public.

The function of film as disseminator of folk songs and kundiman during the American colonial period contributes to both cultural and commercial goals. On one hand, the "cultural goal" reminds the viewing public of heritage. On the other hand, the "commercial goal" benefits from the revival of songs gaining acceptance and making a new form of entertainment that is viable and profitable for decades to follow.

Tagalog imaginary expressed through music in film starts with the use of Tagalog airs. Love songs and kundiman have made its contribution to this imaginary by giving inspiration to a film. The narrative of the sarswela reflects the events transpiring in the community, from stage to film, that expresses the timelessness of Tagalog heritage. Both the kundiman melodrama and the sarswela film go beyond the aural element; as they transmit meanings of awa at pag-asa, lungsod at nayon, balagtasismo, and loob.

Tagalog music and film pass through the process of sacrifices and pleadings (pagtitika at pagmamaka-awa) running parallel to the history of the local people. It evolves and represents Tagalog life in time and space. It expresses imaginaries of experience. The film images show the sentiments, viewpoint, and dreams of a significant Tagalog ethnie-the common folk. These are aural and visual images of the indio, katipunero, magsasaka, and masa.

The Tagalog film, kundiman and folk music complexly reflect the expression of the nation through centuries of colonial experience and of keeping alive the essence of our nation's being amidst the challenges of change. 


\section{Notes}

1. For further reading, see the lecture delivered by Virgilo Almario titled Art and Politics in the Balagtasan.

2. Emmanuel Lacaba puts it this way: "Marahil ang bunga ng pananakop sa atin ay ang pagkalimot, ang pagkawala sa ating loob. Hindi sa tayo ay nagmukmok sa loob, kundi dahil sa paghihimasok ng mga dayuhan, tayo ay nawalan ng tahanan, napalabas tayo sa ating sarili, nawala tayo sa ating loob."

3. This is Jose De Mesa's two-pronged “God-man, man-fellowmen” relationship.

4. This is expressive of Prospero Covar's metaphor of the human body and earthen jar where the individual absorbs the external to fill in one's being. This then leads to introspection by the spirit which dictates the outcome. In Jovita's case, she left the "lungsod" to cleanse herself and went to the extent of entering the nunnery to absorb peace and tranquility. This is also expressive of Ileto's concept that the state of a person's loob can be seen through the events transpiring within the community. 


\section{Glossary}

Chromaticism - A compositional technique interspersing the primary diatonic pitches with the other pitches of the chromatic scale.

Denouement - The final part of a film or narrative in which the strands of the plot are drawn together and matters are explained and/or resolved.

Diegetic Music - Music whose source is visible onscreen or whose source is implied to be present by the action of the film.

Embodied Analogues - Elements of music embody the narrative experience. Quality of sound, dissonances, and modes express the identification of mood or bodily state through mimesis.

Extra-Opus Association (Archetypes) - Music that exists outside a single film. These develop as cultural units through frequent exposure.

Extra-musical - Extrinsic to a piece of music or outside the field of music.

Film Sarswela - A successfully staged sarswela filmed in its entirety.

Imaginary - A field of images, imagination, and deception. The main expressions of this order are synthesis, autonomy, duality, and similarity.

Intra-Opus Association (Leitmotif) -A short recurring musical idea associated with a character, event, place or object.

Kundiman Melodrama - A Filipino melodrama film with music playing an important role in enhancing the cinematic experience. The kundiman as used in films mimics the extra-musical meaning of mercy and hope (awa at pag-asa) signified through its melodic character, text, and tonality. The kundiman melodrama transcends the aural dimension and expresses pain, sorrow, perseverance, and hope embodied through the character/s and the narrative itself.

Linearity Schema - Motion in the narrative vertical space that is represented by pitch, tempo, volume, and register in music.

Narrative - An account of connected events presented in film.

NDM - An acronym for "non-diegetic music."

Non-Diegetic Music - Sound whose source is neither visible on the screen nor 
implied to be present in the action. It is represented as coming from the source outside story space. This is commonly referred to as "background music."

Overture - An orchestral piece at the beginning of an opera, suite, play, oratorio, or other extended composition based on the songs featured in said narrative.

Production number - A spectacular music number that typically includes song/s and dance/s performed by most if not all members of the cast in a motion picture or theater.

Progressive Diegetization - Refers to the process by which music first presented as non-diegetic comes, by the end of the film, to function diegetically.

Sarswela film - One that does not pass through the staged version but rather is commissioned mimicking the structure, aesthetics, and characteristics of a film sarswela.

Semi-Diegetic Speech - Voice-over commentary by one of the characters of the narrative.

Sonic Analogues - The musical depiction of the acoustic characteristics of a sound produced by a character, object, or event. It is closely related to "mickey mousing" originally used for cartoons and later adopted to non-animated films. Size, shape, density, and texture of object determine the pitch range and volume of music.

Stinger - A short piece of music used for emphasizing important spiels or sudden events.

Teleserye - A Tagalog vernacular term that pertains to a television drama series.

Visual Non-Diegetic Insert - A single shot which presents objects exterior to the fictional world of the action. 


\section{Appendix}

\section{Film Timeline}

FILM

Kundiman, Tagalog Film Musicals, and

Other Important Events

1896

- Period:

\section{Beginnings of Film in the Philippines}

- First film apparatus Cronofotografo is brought in by Señor Francisco Pertierra.

\section{Kundiman}

- Jocelynang Baliwag (Kundiman ng Himagsikan) is composed.

1897

- Cinematografo is brought to Manila by Messrs Leibman and Peritz. Live music accompanies the film presentation courtesy of Senor Francisco P. de Barbat.

\section{8}

1899

- Rout of the Filipinos, the first documentary, is filmed and made in the country.

1900

- Carlos Vander Tolosa is born.

- Actuality and Travelogue films are the dominant genres shown.

- Movie houses sprout all over Manila: Cinematografo Parisien; Cinematografo Rizal; Cinematografo Filipino

- Escolta Manila, a film feature, is made.

- Honorata "Atang" dela Rama is born on January 02, 1902. 
- Theater companies are hired as resident artists of movie houses strengthening the film \& live theater combination.

1904

1905

- Fiction films begin to be shown in Manila where the usual fare is actuality films.

1906

1907

1908

- Cinematografo Ideal, owned by the Roces family, is built.

1909

1910

- Majestic Theater, the first modern movie house, opens.

1911

- Ariston Avelino is born.

1912

- Albert Yearsley's La Vida y Muerte del Gran Martir Filipino, Dr. Jose Rizal opens.

- Wagner's Siegfried is shown at Cinematografo Ideal

1913

- Walang Sugat is directed by Albert Yearsley.

1914

1915

- Noli Me Tangere, co-produced by Rizalina Film Manufacturing and Albert Yearsley, is directed by Edward Gross and Albert Yearsley.

1916 


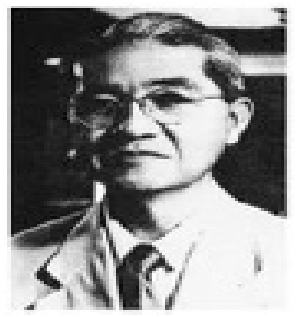

- Jose Nepomuceno puts up Malayan Movies. This event is given the monicker "birth date of the Tagalog cinema."

1918

- Dalagang Bukid, produced by Jose Nepomuceno under Malayan Films, is shown on September 25, 1919. Considered as the first Filipino-produced full-length directed silent film, it stars Atang dela Rama who sang her songs behind the screen during film runs.

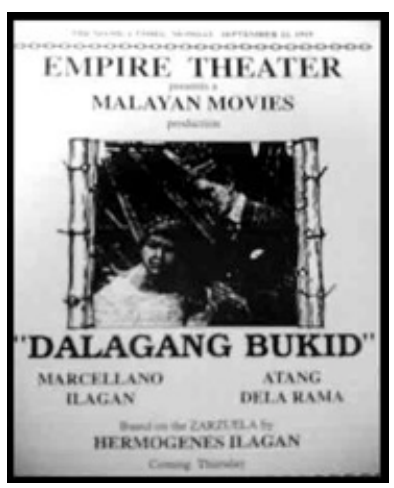

- Elsa Oria, the "Singing Sweetheart of the Philippines" is born on March 24.

- La Venganza de Don Silvestre, a sarswela sequel to Dalagang Bukid, is produced and directed by Jose Nepomuceno. It stars Atang dela Rama and Marceliano Ilagan. 


\section{Kundiman}

- Pakiusap is composed by Francisco Santiago.

1922

1923

1924

1925

1926

\section{Kundiman:}

- "Bituing Marikit" is composed by Nicanor Abelardo.

- "Mutya ng Pasig" is composed by Nicanor Abelardo.

1927

- The Jazz Singer, the first talking picture in the United States of America, starts the sound film and musical genre.

- Salumbides Film Corporation is established.

1928

\section{Kundiman:}

- "Bayan Ko" is set to music by Constancio de Guzman.

1929

- Banahaw Pictures of Julian Manansala is established.

- Syncopation, the first talking picture which arrived in the Philippines from Hollywood, is shown at Radio Theater in Plaza Sta. Cruz, Manila, 1929.

- Minda Mora, a sarswela by Severino Reyes, is is turned into a film sarswela directed by Arthur Matthews.

First Golden Age of Philippine Cinema

- Collegian Love, directed by Carlos Vander Tolosa, is the first sound-on-disc film in the country.

- Film theaters namely Capitol, State, Times, Life, and Avenue located in downtown Manila open circa 1930s. 


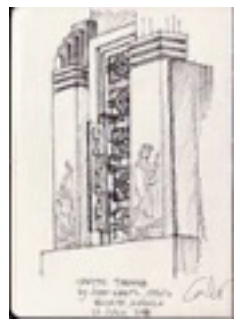

1931

1932

- Ang Aswang, directed by George Musser, is the first sound-on-film film in the country. It opens at Lyric Theater on January 01, 1933.

1933

- Filippine Films owned by George Harris and Eddie Tait pioneers the "studio system" and inaugurates the first sound studio.

- Punyal na Ginto by Jose Nepomuceno is the first Filipino talkie film to be completed. It is shown at the Lyric Theater, Manila.

- Ang Makata at Paraluman, directed by Jose Nepomuceno, is produced by Malayan Pictures and billed as a "100\% all-talking, all-singing musical" with Baritone Francisco Sanchez and soprano Mercedes Ossorio as dubbers.

1934

- Filippine Films is organized in Manila by Steward Tait and George Harris.

- Parlatone Hispano Filipino is inaugurated.

- Secreto de la Confesion is the first all-Spanish, talking and singing picture based on the Liwayway novel entitled Lihim ng Kumpisalan.

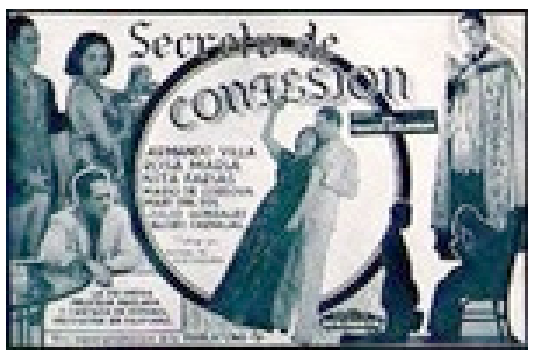

- Kundiman ng Puso is produced by Filippine Films and directed by Eduardo 
de Castro. Considered the first radio-broadcast picture, the film utilizes the best radio talents set against the background of radio studios.

\section{6}

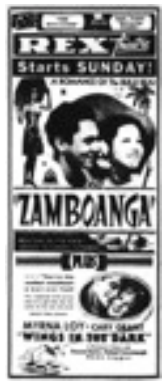

- Zamboanga, directed by Marvin Gardner and produced by Filippine Films is one of the five extant pre-war films. It is shown at the Lyric Theater on December 7-15, 1937.

- Awit Ng Mga Ulila is directed by Mar Esmeralda and produced by Parlatone Hispano Filipino.

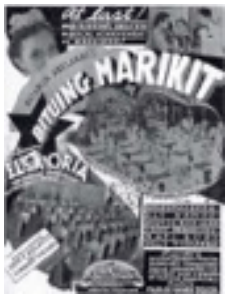

- Sampaguita Pictures, owned by Congressman Pedro Vera, inaugurates and produces Bituing Marikit, a musical romance directed by Carlos Vander Tolosa.

- Nasaan Ka Irog is directed by Carlos Vander Tolosa for Parlatone Hispano Filipino.

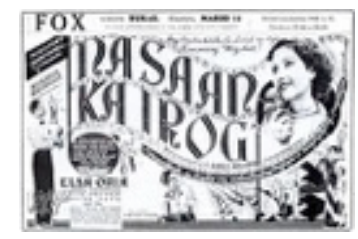

- Madaling Araw is directed by Carlos Vander Tolosa for Sampaguita Pictures. 
- Excelsior Films, owned by Ramon Araneta, is inaugurated.

- Bahay Kubo, directed by Gerardo de Leon and produced by Parlatone Hispano-Filipino, is the story of a poor country girl who becomes a great opera singer and of her brother, a great violinist. It stars Josefino Cenizal, Mona Liza, and Fely Vallejo.

- 48 Films are produced this year.

- LVN Pictures, owned by Narcisa de Leon, Carmen Villiongco, and Eleuterio Navoa, is inaugurated.

- Del Monte Pictures is formed by Mauricio Guidote as president.

- Ang Maya, Excelsior Film's first production, is directed by Jose Nepomuceno and features coloratura soprano, Consuelo Salazar.

- Madaling Araw is directed by Carlos Vander Tolosa and produced by Sampaguita Pictures Inc.

Release Date: October 11-25, 1938 at the Metropolitan Theater.

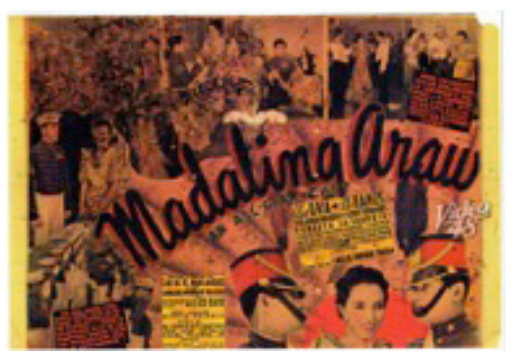

- Paroparong Bukid is directed by Octavio Silos and produced by Sampaguita Pictures Inc.

Release Date: May 31- June 12, 1938 at the Grand Theater.

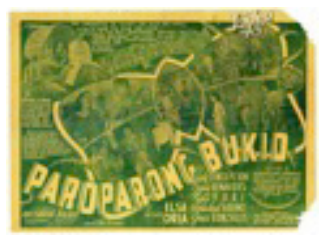




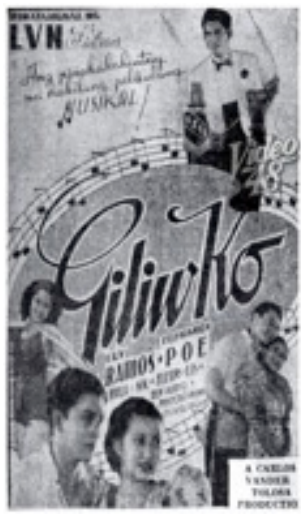

- Giliw Ko opens at Manila Metropolitan Theater with Commonwealth President Manuel L.Quezon in attendance. It is one of the five pre-war extant films.

- Tunay Na Ina is directed by Octavio Silos for Excelsior Films opens. It is one of the five pre-war extant films.

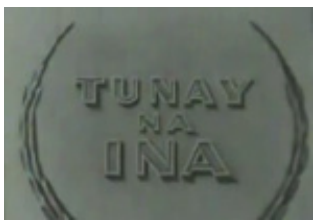

- X'Otic Films is established with Jesus Cacho as president.

- Mahiwagang Binibini, based on the sarswela, Ang Kiri, is directed by Don Servando Angeles with Prof. Leon Ignacio as Musical Director. Produced by Excelsior Films, it stars Atang dela Rama.

Release Date: April 5-11, 1939 at the Grand Theater.

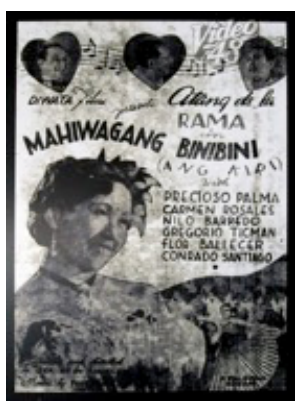


- Walang Sugat is directed by Enrique Herrera Davila and produced by Philippine Films. It stars Rosa de Rosario and Leopoldo Salcedo. Release Date: June 6-14, 1939 at the Strand Theater.

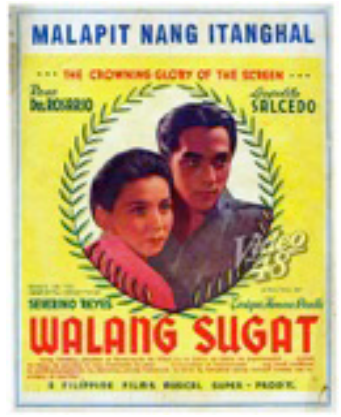

- Lagot na Kuwintas is directed by Carlos Padilla and produced by Sampaguita Pictures Inc.

Release Date: February 24- March 2, 1939 at the Grand Theater.

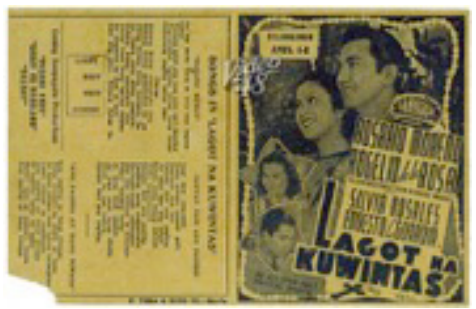

- Ruisenor is directed by Mar I. Esmeralda and produced by Parlatone Pictures. Release Date: April 8- 21, 1939 at the Fox Theater.

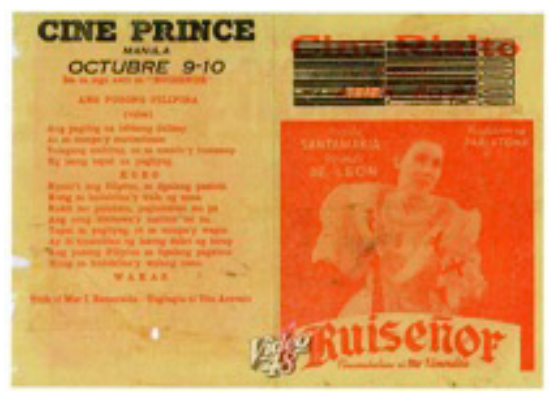

- Yaman ng Mahirap is directed by Carmen Concha and produced by Parlatone Production.

Release Date: August 25- 31,1939 at the Grand Theater. 


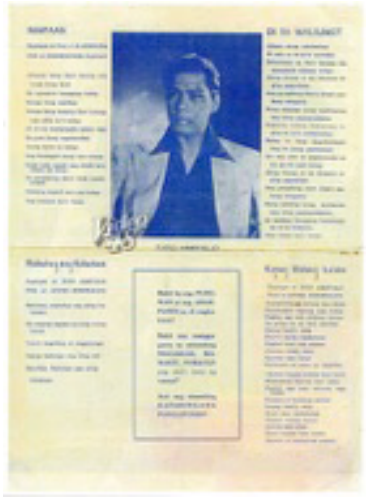

- Hanggang Langit is directed by Ted del Rio and produced by Manila Films. Release Date: November 11, 1939 at the Metropolitan Theater.

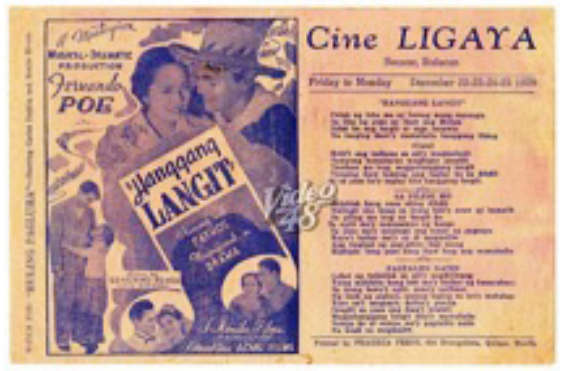

- Ang Magsasampaguita is directed by Gregorio Fernandez and produced by Sampaguita Picures.

Release Date: November 22- 29, 1939 at the Grand Theater.

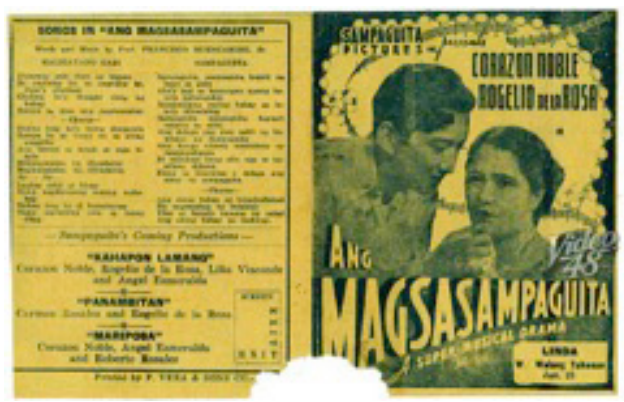

- Takip-Silm is directed by Don Danon and produced by Sampaguita Pictures. Release Date: December 28, 1939-January 5, 1940 at the Grand Theater. 


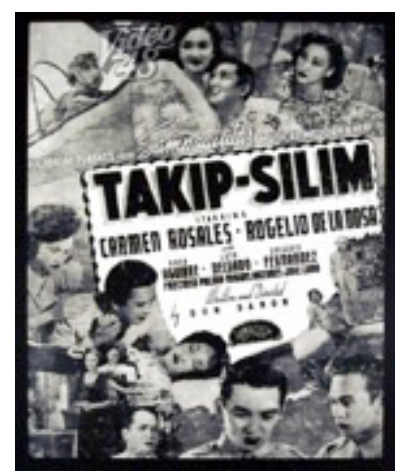

- 50 films are produced this year.

- Pakiusap, directed by Octavio Silos for Excelsior Films, opens. It is one of the five pre-war extant films.

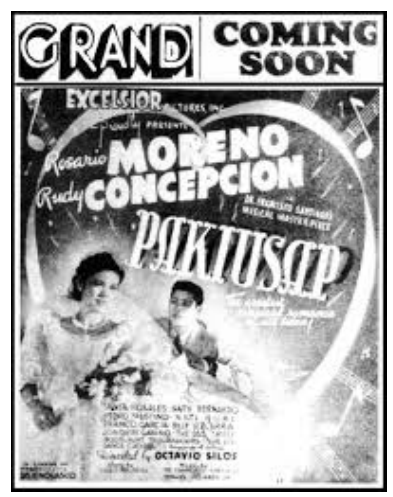

- Lambingan is directed by Lorenzo P. Tuells and produced by Sampaguita Pictures.

Release Date: July 7-16, 1940 at the Grand Theater. 


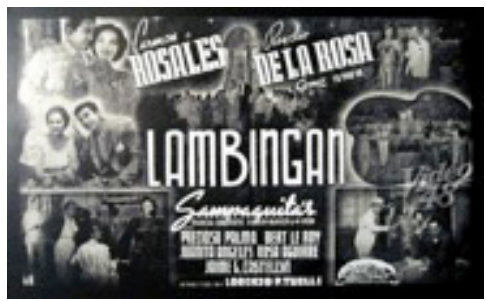

- Inday produced by Filippine Films, is directed by Lamberto V. Avellana with story by Daisy Hontiveros-Avellana.

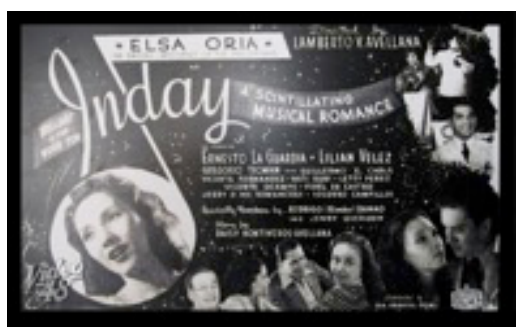

- Mahal Pa Rin Kita is directed by Jesus Carreon and produced by Excelsior Pictures, Inc. The story is by Agustin V. Reyes and music by Constancio de Guzman.

Release Date: September $21-27,1940$ at the Grand Theater.

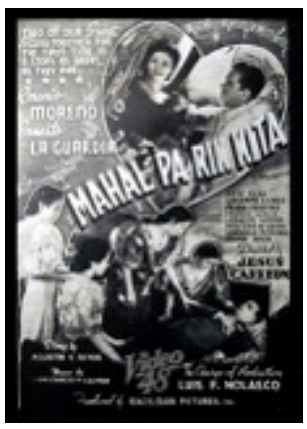

- Lambingan is directed by Lorenzo P. Tuells and produced by Sampaguita Pictures Inc.

Release Date: July 7-16, 1940 at the Grand Theater. 


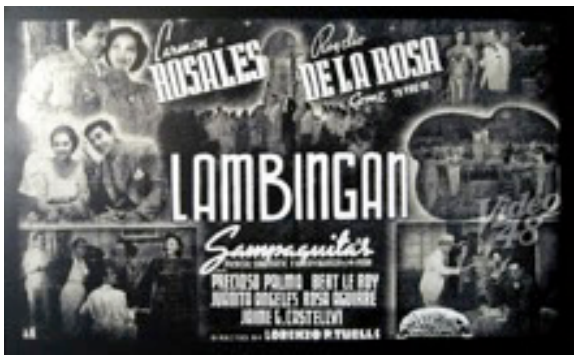

- Prinsesa ng Kumintang (Operetta Filipina), directed by Gerardo de Leon with Tito Arevalo as musical director, is produced by LVN Pictures.

- Ikaw Rin is directed by Octavio Silos and produced by Excelsior Pictures, Inc. It stars Elsa Oria and Rudy Concepcion (his last movie).

Release Date: July 17-24, 1940 at the Grand Theater.

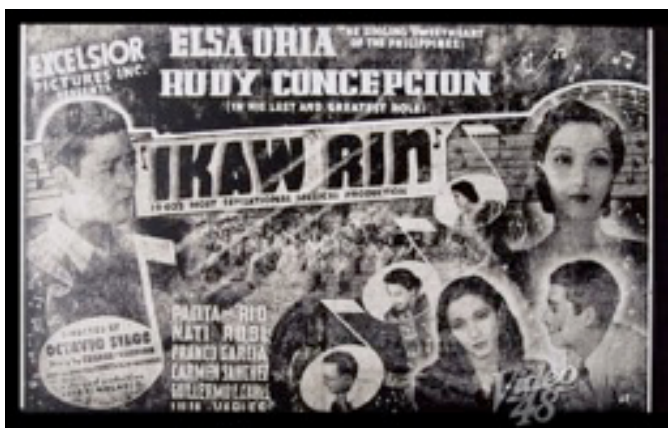

- Magbalik Ka Hirang is directed by Lorenzo Perez Tuells and produced by Sampaguita Pictures Inc.

Release Date: March 14-18, 1940 at the Grand Theater.

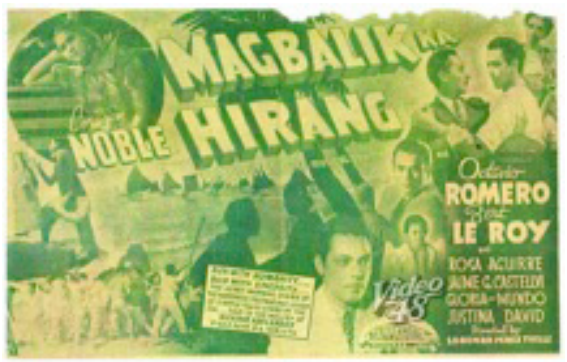

- Jasmin is directed by Don Danon and produced by Sampaguita Pictures Inc.

Release Date: April 18-24, 1940 at the Grand Theater. 


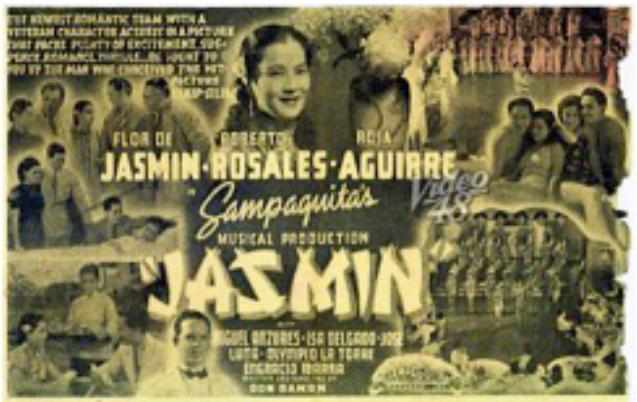

- Huling Pagluha is directed by Arthur Gottlein and produced by Minerva Pictures with music by Prof. Juan Silos, Jr. and orchestrations by Carlos Valdes.

Release Date: May 3- 8, 1940 at the Grand Theater.

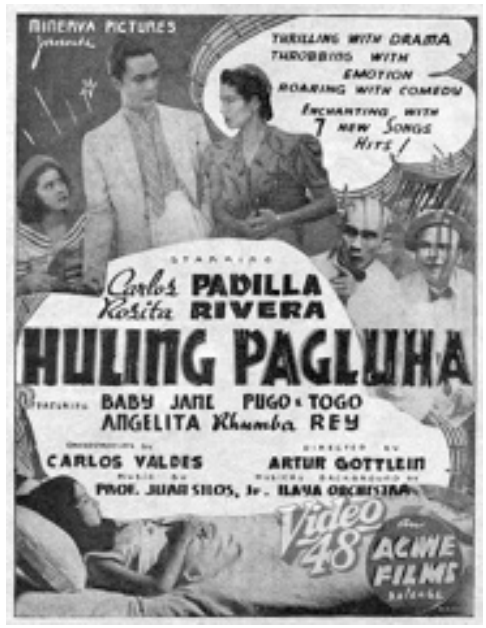

- Cariñosa is directed by Carlos Padilla and produced by Sanggumay Pictures with music by Constancio de Guzman.

Release Date: October 7- 14, 1940 at the Fox Theater. 


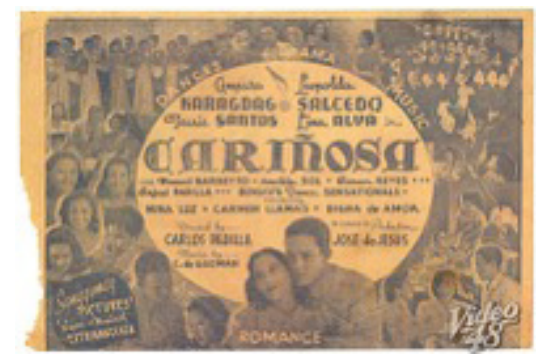

- Nagiisang Sangla is directed by Tor Villano and produced by LVN Pictures. It stars Leopoldo Salcedo and Mila Del Sol.

Release Date: November 14-20, 1940 at the Grand Theater.

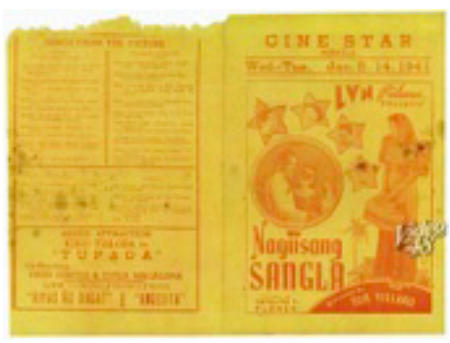

- Mahal Pa Rin Kita is directed by Jesus Carreon and produced by Excelsior Pictures, Inc. with story by Agustin V. Reyes and music by Constancio de Guzman,

Release date: September $21-27,1940$ at the Grand Theater.

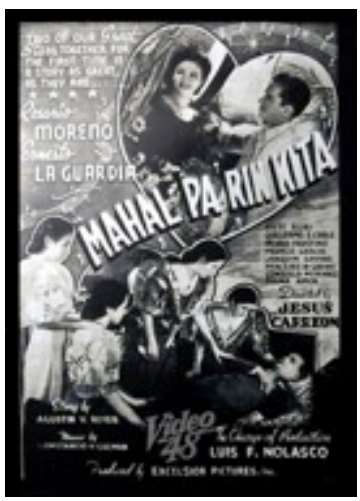

- Alitaptap is directed by Lamberto Avellanaz

- Panambitan is directed by Gerardo de Leon.

- Tampuhan is directed by Lorenzo Tuells.

- A total of 57 films are produced this year. 


\section{Danza}

- Maala-ala Mo Kaya is composed by Constancio de Guzman.

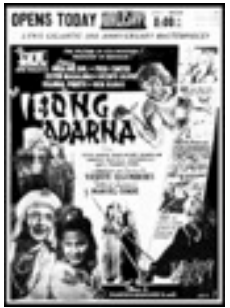

- Ibong Adarna, directed by Vicente Salumbides for LVN Pictures, opens. It is one of the five pre-war extant films. In scenes where the Adarna sings, the bird is shown in color (hand coloring of film).

- Kundiman is produced by Excelsior Pictures, Inc. with music by Miguel Velarde, Jr. from Dr. Francisco Santiago's composition. The story and screenplay are by Luis F. Nolasco with direction by Ramon Estella. Release Date: January 9-15, 1941 at the Grand Theater.

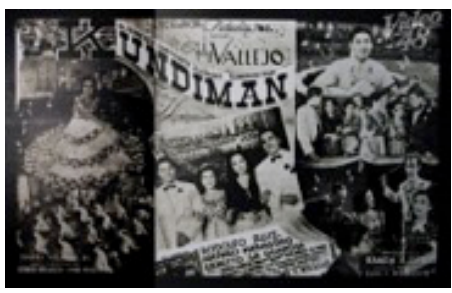

- Ibong Sawi is produced by Excelsior Pictures, Inc. The story is by Susana C. de Guzman, music by Constancio de Guzman, and direction by Octavio Silos.

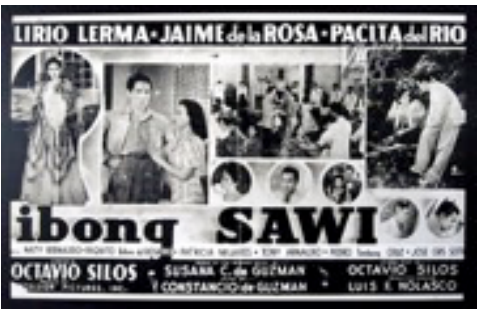

- Ang Viuda Alegre, an operetta by Franz Lehar, is directed by Enrique Herrera Davila and produced by Eduardo de Castro. It stars Lucita Goyena and Fernando Poe. 


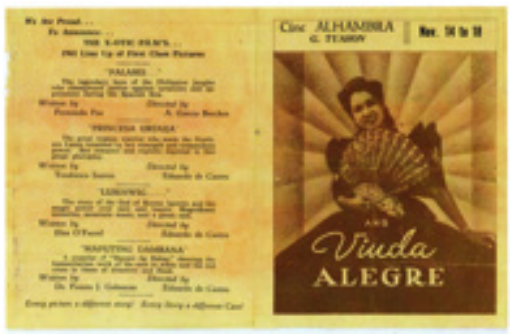

- Binibini ng Palengke is directed by Carlos Vander Tolosa and produced by Filippine Films with music by Ariston Avelino.

Release Date: April 19-28, 1941 at the Dalisay Theater.

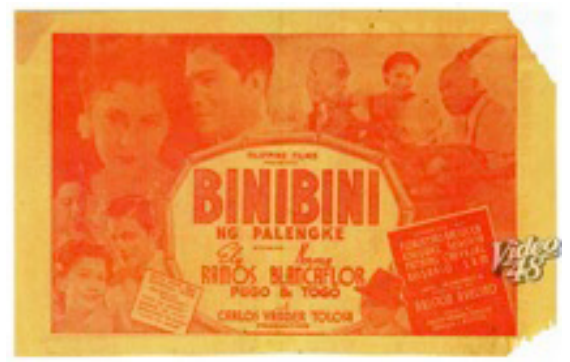

- Rosalinda is directed by Lamberto Avellana and produced by LVN Pictures, with music by Francisco Buencamino, Sr. and Francisco Buencamino, Jr. Release Date: April 29- May 6, 1941 at the Dalisay Theater.

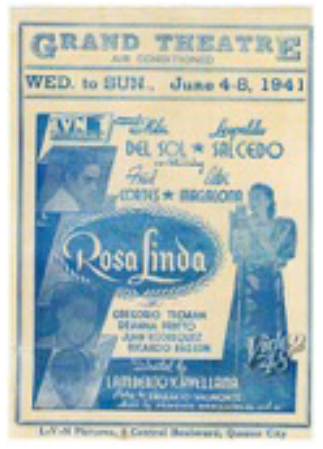




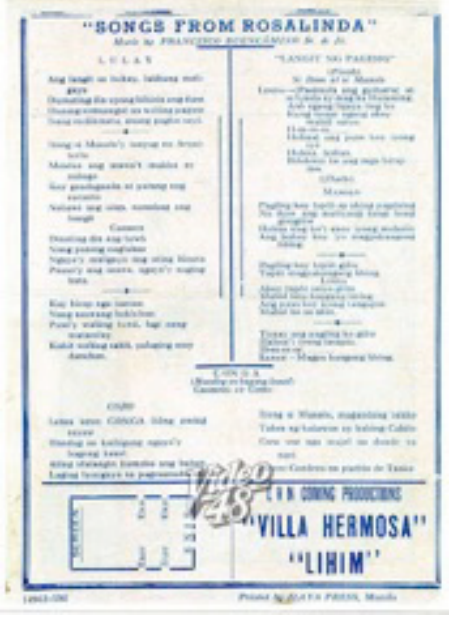

- Babalik Ka Rin is directed by Octavio Silos and produced by Excelsior Pictures, Inc. Music is by Miguel Velarde Jr. and story is by Luis Garchitorena.

Release Date: September 6-11, 1941 at the Dalisay Theater.

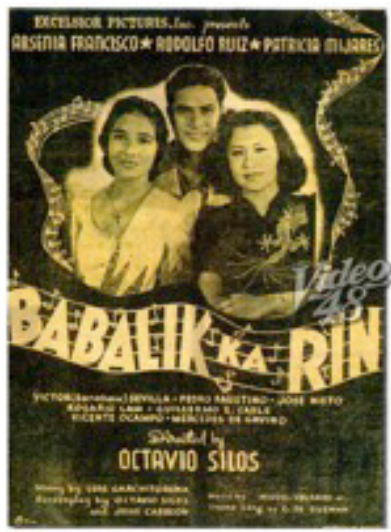

- Ikaw Pala is directed by Lamberto V. Avellana and produced by LVN Pictures. The story is by Jovita Martinez Memije and music is by Francisco Buencamino Jr.

Release Date: November 21- 271941 at the Dalisay Theater. 

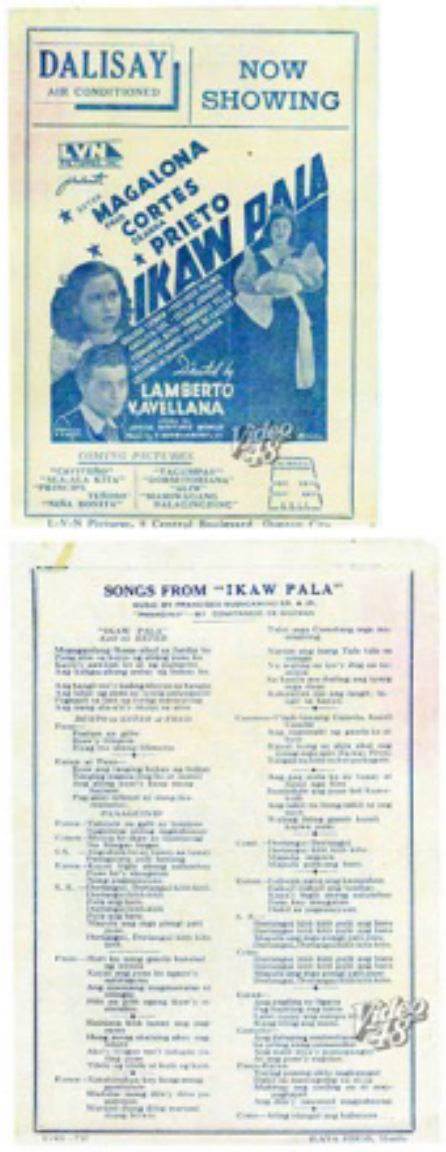

- Serenata sa Nayon is directed by Carlos Vander Tolosa and produced by Sampaguita Pictures Inc. with music by Mike Velarde.

- Ararong Ginto, a sarswela by Servando delos Angeles, is directed by Manuel Conde and produced by LVN Pictures with music by Juan Silos, Jr. It stars Mila del Sol and Leopoldo Salcedo. 


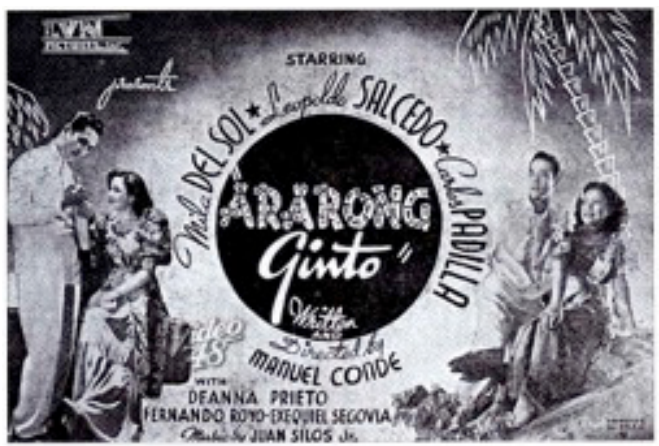

- Nolasco Bros. Pictures, Inc. is organized by Luis F. Nolasco.

- Tampuhan is directed by Lorenzo Tuells and produced by Sampaguita Pictures Inc. It stars Carmen Rosales and Rogelio de la Rosa.

Release Date: September 19- October 1, 1941 at the Dalisay Theater.

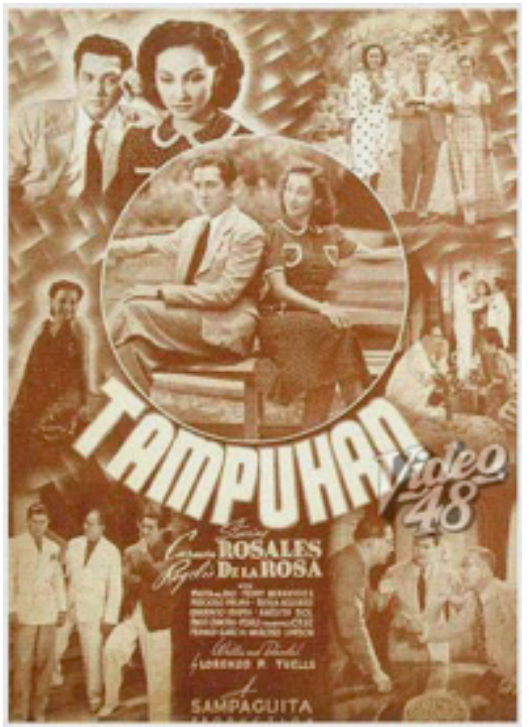

- Caballero RDR is shown during WW2 on March 1-25, 1942 at the Life Theater.

- Caviteño is directed by Manuel Conde and produced by LVN Pictures. It is shown during WW 2 from March 12-April 3, 1942 at the Dalisay Theater. 


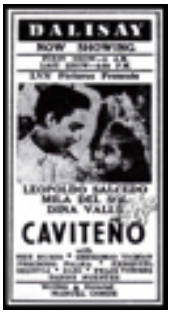

- Anong Ganda Mo (1941) is directed by Gerardo de Leon, produced by RDR, and shown during WW2 on May 9, 1942 at the Life Theater.

- Niña Bonita is produced by LVN Pictures and shown during WW2 on June 9-July 2 at the Dalisay Theater. (No director credit in IMDb.)

- Princesa Urduja is produced by X-Otic Films and shown on November 13, 1942 at the Ideal and Times Theaters. (No director credit in IMDb.)

- Landas na Ginto is produced by Sampaguita Pictures and shown during WW2 on December 26, 1942- January 9, 1943 at the Dalisay Theater.

- Principe Teñoso is directed by Manuel Conde and produced by LVN Pictures. Produced during wartime, it is shown on October 3, 1942 at the Ideal Theater.

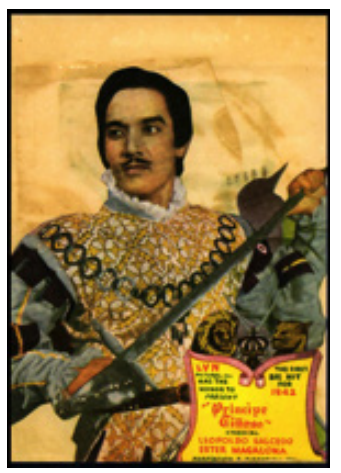

1943

- Tia Juana by LVN is produced during wartime and shown on May 27, 1943 at the Lyric Theater.

- Dawn of Freedom by Toho Film Distributing Co. is directed by Gerardo de Leon and Yutaka Abe.

Release Date: March 8- 22, 1944 at the Lyric and Ideal Theaters. 


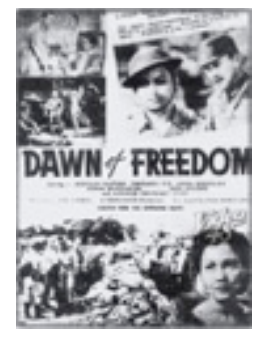

- Perfidia is shown on May 30, 1944 at the Life Theater.

- Tatlong Maria by Tojo Film distributing Co. is directed by Gerardo de Leon. The movie had grand musical numbers shot at the Manila Hotel and the Manila Jai Alai Building.

Release Date: October 12-19, 1944 at the Ideal and State Theaters.

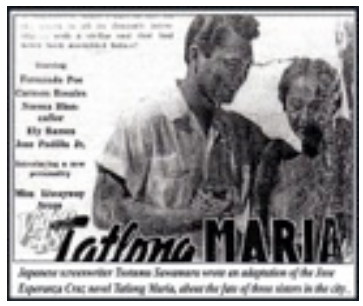

\section{Second Golden Age of Philippine Cinema}

- Premiere Productions is established with Dr. Ciriaco Santiago as president.

- Orasang Ginto, the first production of LVN Pictures after the war, is directed by Manuel Conde and is shown from March 4-12, 1946.

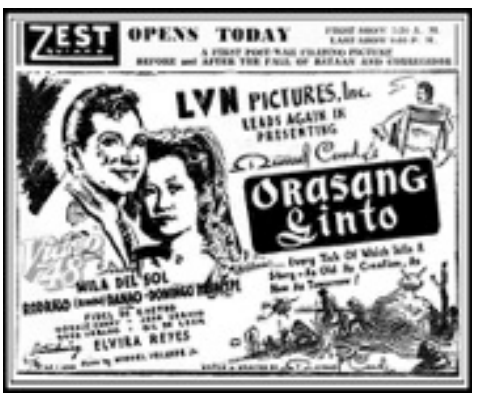


- Ulilang Watawat, the first production of Sampaguita Pictures after Liberation, is directed by Octavio Silos who also wrote the story. Release Date: May 31- June 11, 1946 at the Dalisay Theater.

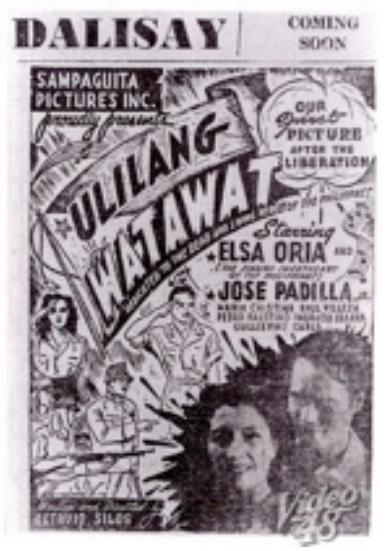

- Ligaya is produced by Oriental Pictures with directorial supervision by Manuel Silos and music by Prof. S.S. Suarez.

Release Date: November 30-December 12, 1946 at the Dalisay Theater.

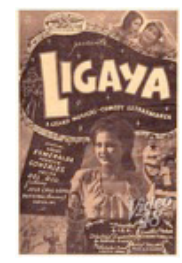

- Principeng Hindi Tumatawa is produced by LVN Pictures and directed by Manuel Conde with the story by Dona Aurora Vda. de Quezon and music by Francisco Buencamino, Sr. and Francisco Buencamino, Jr. Release Date: October 13- 24, 1946 at the Life Theater. 


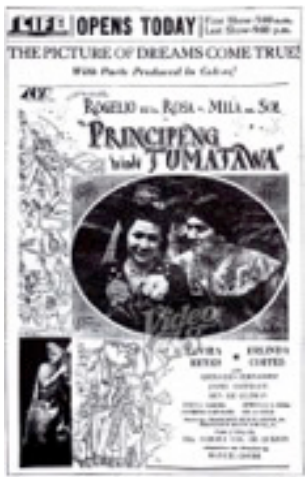

- Awit ni Palaris is directed by Fernando Poe and produced by Palaris Films with screenplay by T.D. Agcaoli and music by Lucio San Pedro.

Release Date: October 25- November 5, 1946 at the Illusion Theater.

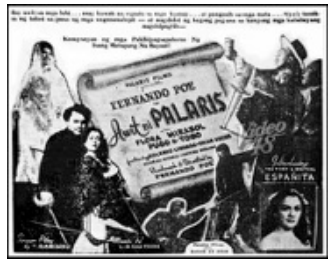

- Sarung Banggi (Isang Gabi) is produced by LVN Pictures, Inc. with story and direction by Susana C. de Guzman, music by Constancio de Guzman, and photography by Enrique Rosales.

Release Date: December 28, 1947-January 14, 1948 at the Dalisay Theater.

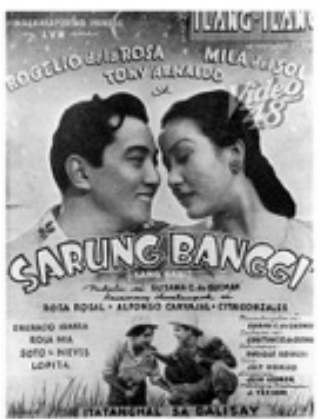

- Bakya Mo Neneng is produced by Premiere Productions, Inc. Release Date: April 30, 1947 at the Dalisay Theater. 


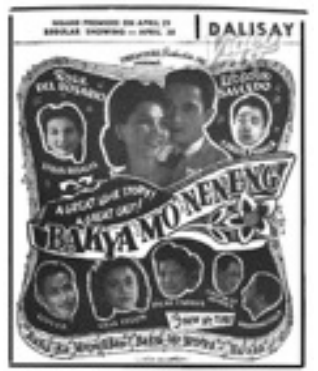

- Hagibis is produced by Fernando Poe Production and Palaris Films with direction by Fernando Poe and music by Lucio San Pedro.

Release Date: November 1947.

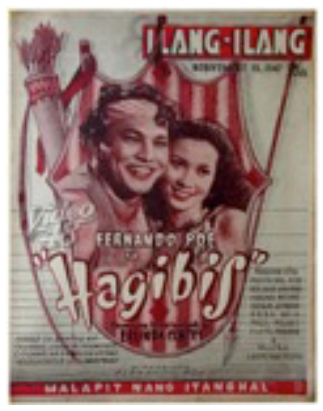

- Sa Kabukiran is produced by Philippine Pictures, Inc. with direction by Joe Climaco and music by Manuel P. Velez.

Release Date: December 3-7, 1947 at the Dalisay Theater.

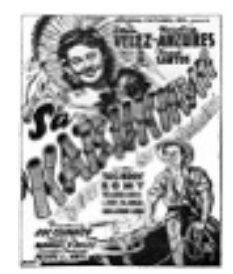

- Tani: Lord of the South Seas is produced by Leyte Motion Pictures with story and direction by Tor Villano and music by Felipe P. de Leon.

Release Date: June 1947 at the Center Theater. 


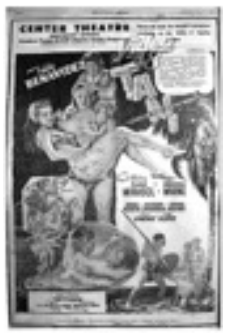

- Nabasag ang Banga is produced by Oriental Pictures, Inc. with direction by

- Manuel Conde and music by S.S. Suarez.

Release Date: April 10-24, 1947 to January 14, 1948 at the Bataan Theater.

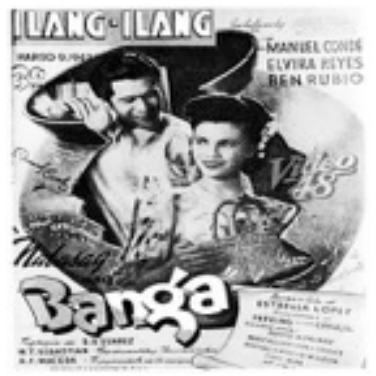

- Ikaw ang Mahal Ko is produced by Oriental Productions. A. F. Maceda is in charge of production and S.S. Suarez of music.

Release Date: May 31- June 8, 1947 at the Boulevard Theater.

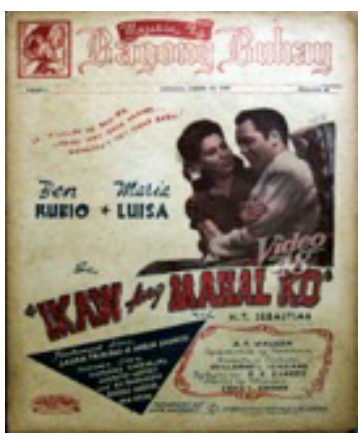

- Manuel Conde Productions is established. 


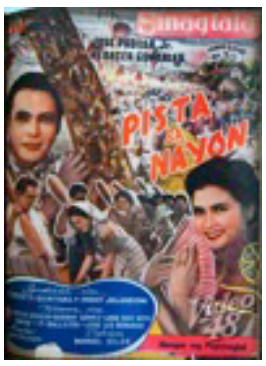

- Pista sa Nayon is produced by LVN Pictures, Inc. with direction by Manuel Silos and music by Quin Velasco.

Release Date: September 21-30, 1948 at the Dalisay Theater.

- Sa Tokyo Ikinasal is produced by LVN Pictures, Inc. and directed by Manuel Silos.

- Sa Tokyo Ikinasal is a film version of a zarzuela called On To Tokyo by Pedrito Reyes. But the story is really a Filipino adaptation of the famous opera by Giacomo Puccini, Madame Butterfly.

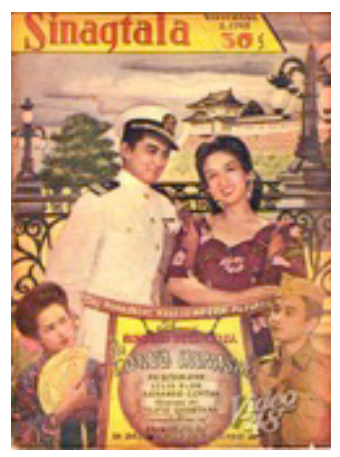

- Pista sa Nayon is directed by Manuel Silos and produced by LVN Pictures, Inc. with music by Quin Velasco.

Release Date: September 21-30, 1948 at the Dalisay Theater. 


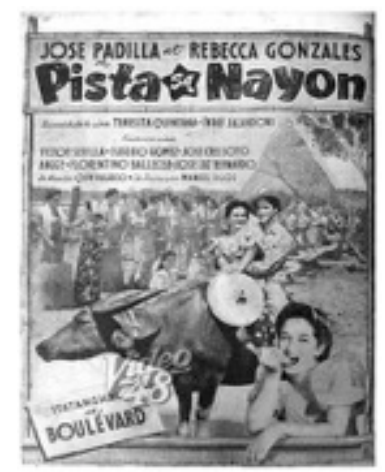

- Itanong Mo sa Bulaklak is directed by Paquito Bolero and produced by Premiere Productions with music by Antonio Maiquez. Release Date: June 8- 2, 1948 at the Dalisay Theater.

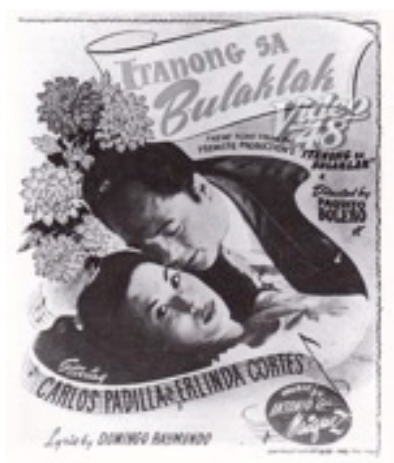

- Dolorosa is directed by Estrella Alfon-Rivera and produced by Leyte Motion Pictures with music by Josefino Cenizal.

Release Date: June 11-16, 1948 at the Center Theater.

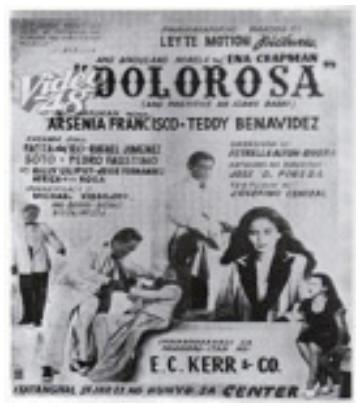


- Beast of the East is directed by Carlos Vander Tolosa and produced by Don Jesus Cacho with music by J.E. Anguita and B. Custodio.

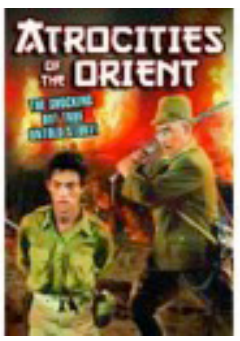

- Hindi Kita Malimot is produced by Sampaguita Pictures and stars Carmen Rosales and Leopoldo Salcedo.

- Simpatika is directed by Octavio Silos and produced by Sampaguita Pictures. Release date: February 20- 28, 1949 at the Life Theater.

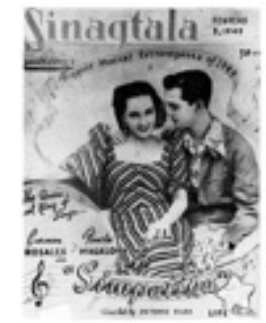

- Ang Lumang Simbahan is directed by Luis F. Nolasco and Guillermo J. Icasiano and produced by Nolasco Bros. Pictures with music by Josefino Cenizal.

Release Date: March 2- 21, 1949 at the Life Theater.

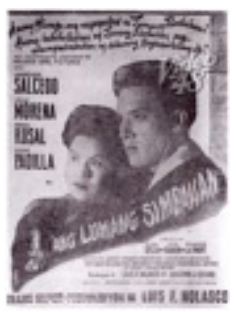

- Dasalang Ginto is directed by Moises Caguin and initially presented by Filcudoma Pictures with music by Ray Alinsod.

Release Date: December 4- 14, 1949 at the Dalisay Theater. 


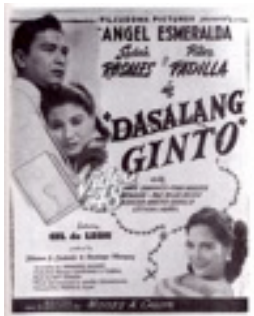

- Ang Kandidato is directed by Joe Climaco and produced by LVN Pictures with story by Alex Sunga and music by Juan Silos.

Release Date: April 1, 1949 at the Life Theater.

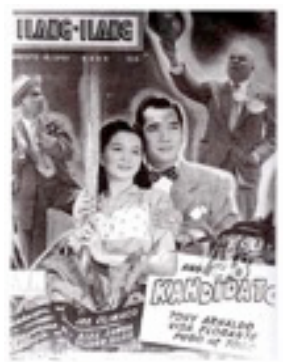

- Fernando Poe Productions, Inc. is established by Fernando Poe.

- Padilla Bros. Productions, Inc. is established by the Padilla Family.

- Lebran Inc. is established by William M.A. Brant with the objective of producing English language local films for international release.

\section{0}

- His Darkest Hour is directed by Antonio Verches and produced by Lebran Films with music by J.E. Anguita.

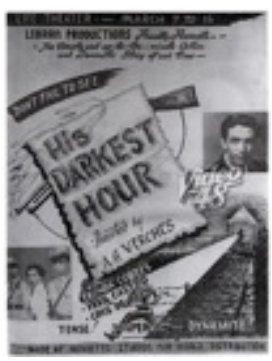


- Song of Sto. Tomas is produced by Lebran Productions with screenplay by Robert Hill.

Release Date: May 26- June 5, 1950 at the Life Theater.

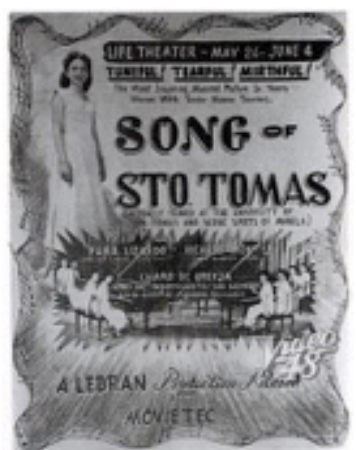

1951

- Huling Konsiyerto is produced by Benito Bros. Pictures with story and direction by Don Alcaraz and music by Levi Celerio. Release Date: July 20-29, 1951 at the Life Theater.

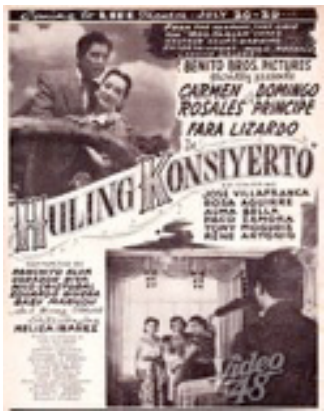

1952

Efren Reyes Productions is established. 


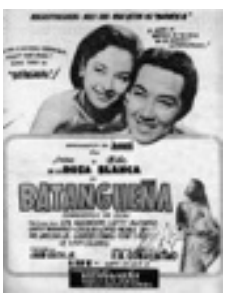

- Batanguena is directed by F.H. Constantino for LVN Pictures.

- Sa Isang Sulyap Mo, Tita (1953) directed by Armano Garces, music by Tirso Cruz and his Manila Hotel Orchestra, produced by Sampaguita Pictures. Cast: Tita Duran, Pancho Magalona. Release Date: August 8-17, 1953.

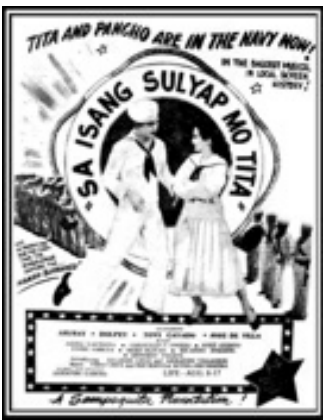

- The Great Singer is directed by Carlos Vander Tolosa for Filmmasters Production with a story of Christmas in Manila. It stars Arrigo Pola, Italian tenor.

- Vod-A-Vil is directed by Olive La Torre and produced by Sampaguita Pictures with music by Tirso Cruz and his Manila Hotel Orchestra. Release Date: December 21, 1953 at the Dalisay Theater.

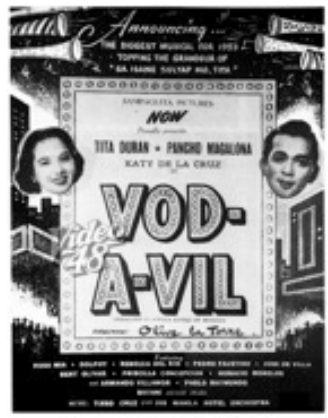


- Waray Waray is directed by F.H. Constantino for LVN Pictures.

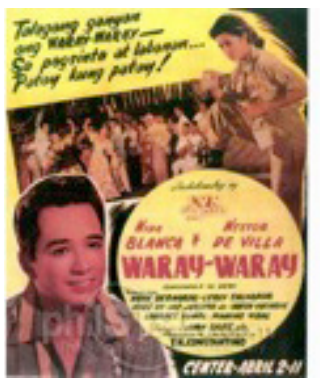

- Maalaala Mo Kaya? is directed by Mar S. Torres and produced by Sampaguita Pictures. It stars Carmen Rosales and Rogelio de la Rosa. Release Date: January 22- February 2, 1954 at the Center Theater.

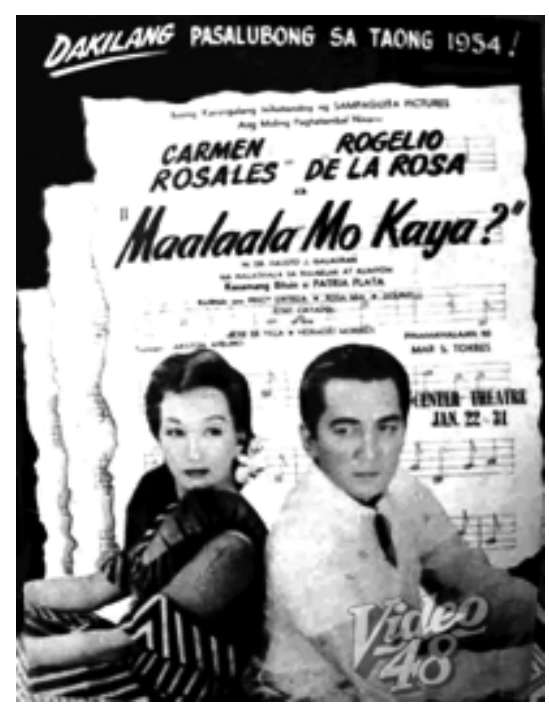

- Sa Isang Halik Mo Pancho is directed by Armando Garces and produced by Sampaguita Pictures with music by Tirso Cruz and his Manila Hotel Orchestra.

Release Date: July 13, 1954 at the Center Theater. 


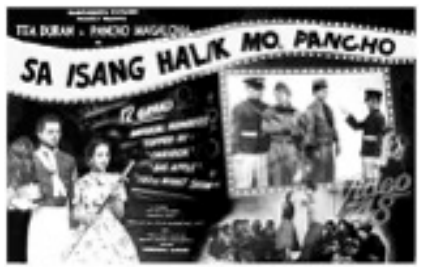

1955

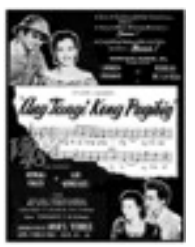

- Ang Tangi Kong Pag-ibig is directed by Mar S. Torres for Sampaguita Pictures with music by Constancio de Guzman.

- Ikaw Kasi is directed by Manuel Conde with music by Francisco Buencamino, Jr. and Juan Silos, Jr. Produced by LVN Pictures, it stars Nida Blanca, Nestor de Villa, Nenita Vidal, and Manding Claro.

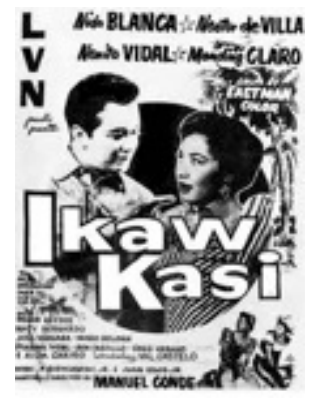

Ikaw Ang Buhay Ko is directed by Billy Icasiano and produced by LVN Pictures with music by S.S. Suarez. 


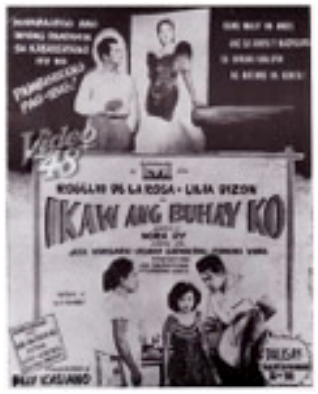

- Higit Sa Lahat is directed by Gregorio Fernandez and produced by LVN Pictures with music by Santiago Suarez.

Release Date: April 30, 1955 at the Life Theater.

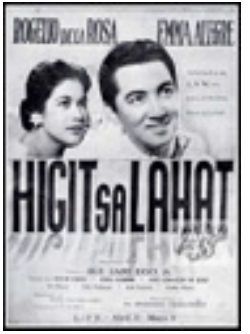

- Dalaga't Binatilyo is directed by Armando Canseco and produced by LVN Pictures with music by Juan Silos, Jr.

Release Date: January 10, 1955 at the Life Theater.

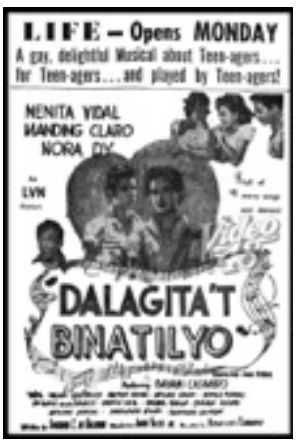

- Bahala Na, directed by Manuel Conde, music by Juan Silos Jr., produced by LVN Pictures. Musical extravaganza using the "Magnascope" a wide-screen process technology. 


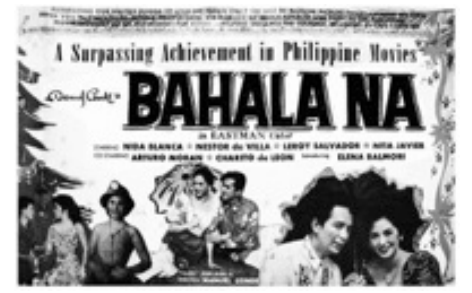

- Anak Dalita is directed by Lamberto Avellana and produced by LVN Pictures with music by Francisco Buencamino, Jr. The title comes from the kundiman of Nicanor Abelardo.

Release Date: March 20-29 at the Dalisay Theater.

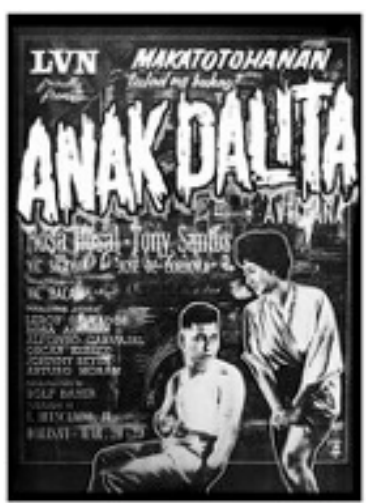

- Sweethearts is directed by Gerardo de Leon and produced by Cirio Santiago Film Organization.

Release Date: September 16-25, 1957 at the Life and Center Theaters.

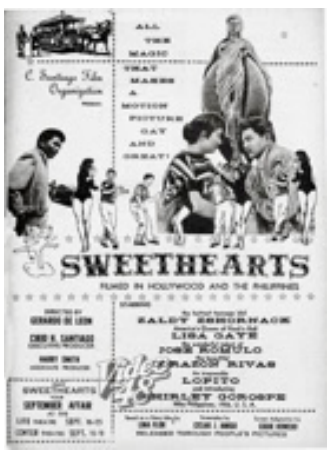


- Walang Sugat is directed by Lamberto Avellana and produced by LVN Pictures.

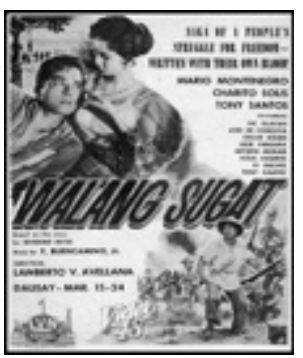

- Bituing Marikit is directed by Carlos Vander Tolosa and produced by Sampaguita Pictures with music by Nestor Robles.

Release Date: March 20, 1957 at the Life Theater.

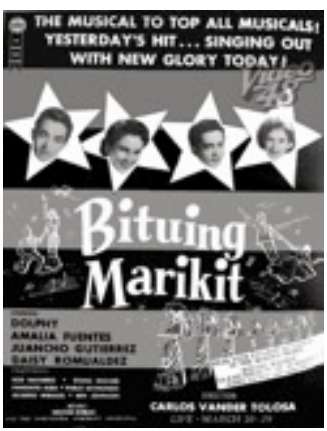

- Paruparong Bukid is directed by Armando Garces and produced by Sampaguita Pictures with music by Nestor Robles. Release Date: December 15, 1957.

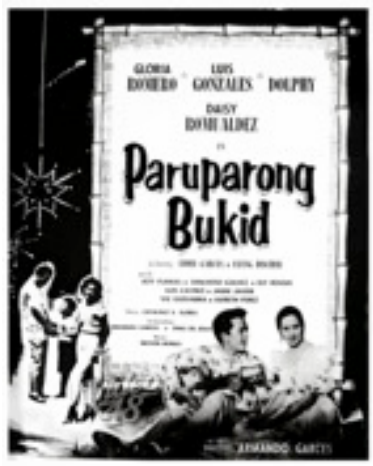


- Combo Festival is directed by Manuel Silos and produced by LVN Pictures with music by Polding Silos. The film features 22 combos or bands, winners of the National Combo Contest from all over the Philippines.

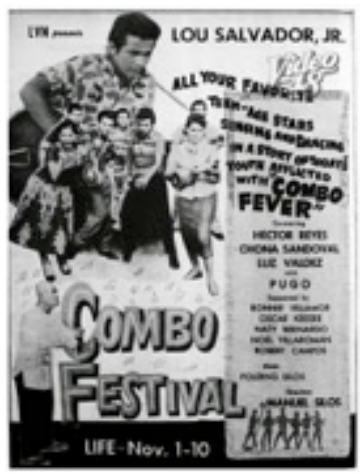

- Film Academy of Movie Arts and Sciences (FAMAS) is established this year.

- Madaling Araw is directed by Armando Garces and produced by Sampaguita Pictures with music by Nestor Robles. Release Date: July 03, 1958 at the Life Theater.

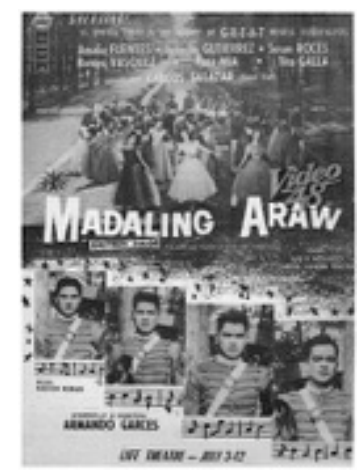

- Tuloy Ang Ligaya is directed by Manuel Silos and produced by LVN Pictures with music by Pepe Merto.

Release Date: May 24, 1958 at the Life Theater. 


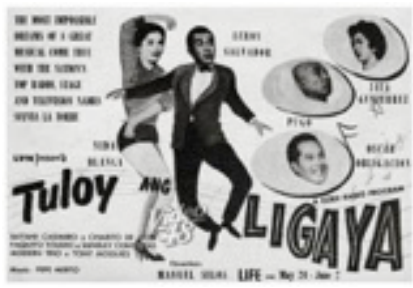

1959

- Sa Libis ng Nayon is directed by Mar Torres and produced by Vera-Perez Productions with music by Constancio de Guzman.

Release Date: July 04-13 at the Dalisay Theater.

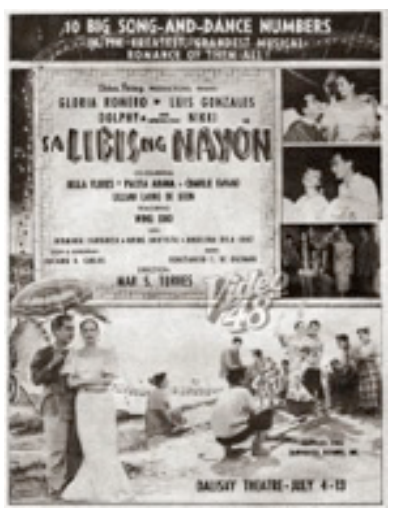

- Pakiusap is directed by Conrado Conde and produced by Sampaguita Pictures, Inc. with music by Constancio de Guzman.

Release Date: September 22- October 1, 1959 at the Dalisay Theater.

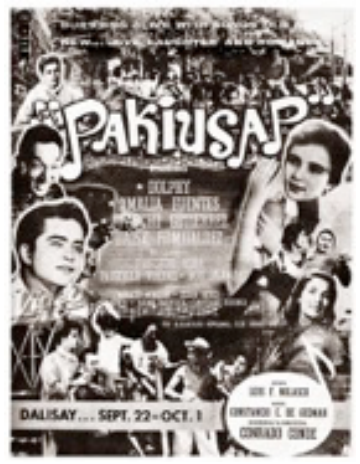


- Maturan at Lagman is directed by Natoy Katindig and produced by LVN Pictures with music by Francisco Buencamino, Jr. Performances are provided by Diomedes Maturan, Pugo, Lopito, Patsy, Bentot, Marita Zobel, Mila Ocampo.

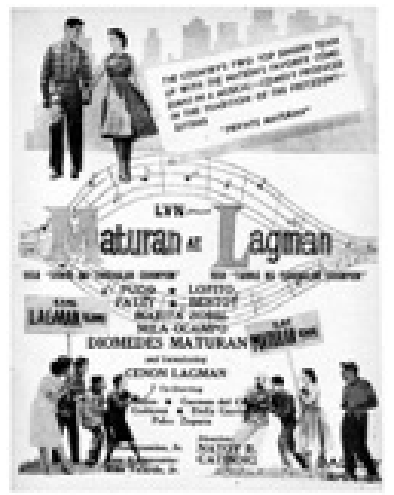

- Beatnik is directed by Tony Cayado and produced by Jose O. Vera with music by Carding Cruz.

Release Date: January 20-29 at the Dalisay Theater.

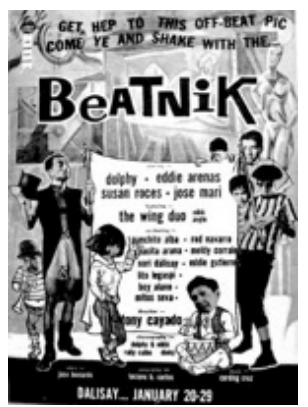

- Kung Ako'y Mahal Mo is directed by Gregorio Fernandez and produced by LVN Pictures with music by Polding Silos. 


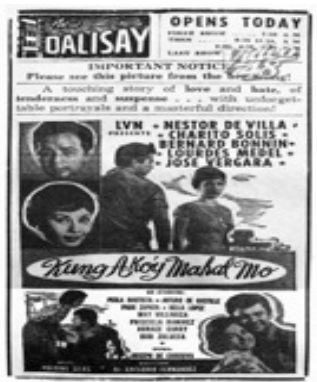

- Doon Po Sa Amin is directed by Natoy Catindig and produced by LVN Pictures with music by Francisco Buencamino, Jr.

Release Date: December 21, 1960 at the Center Theater.

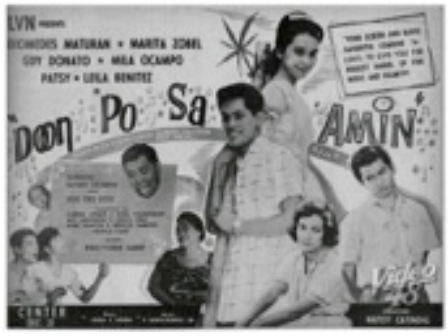

1961

- Joey, Eddie and Lito is directed by Mar S. Torres and produced by Vera Perez Productions with music by Pastor de Jesus.

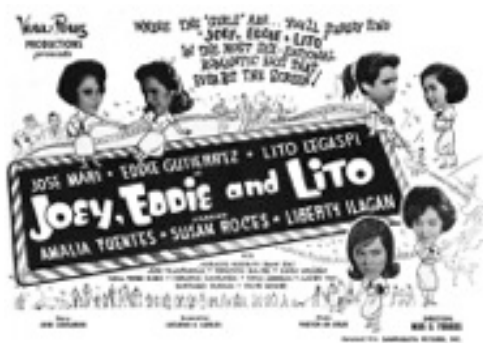

- The Big Broadcast is a musical directed by Tony Cayado and produced by Sampaguita Pictures. It is considered as a superproduction. 


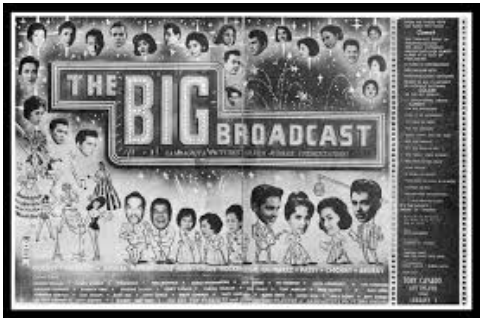

- Jam Session is directed by F.H. Constantino and produced by Dalisay Pictures with music by Polding Silos.

Release Date: May 19 at the Dalisay Theater.

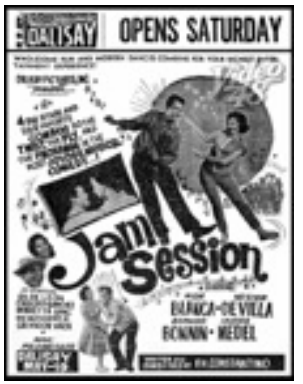

1963

- Dance-O-Rama is directed by Tony Cayado and produced by Sampaguita Pictures with music by Danny Holsem.

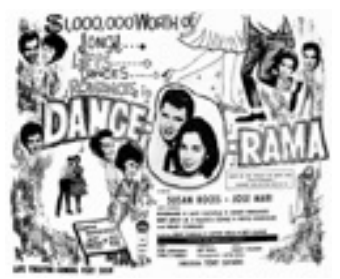

Third Golden Age of Philippine Cinema

- Everybody Dance is directed by F.H. Constantino and produced by Dalisay Pictures with choreography by Al Quinn.

Release Date: June 08, 1964 at the Dalisay Theater. 


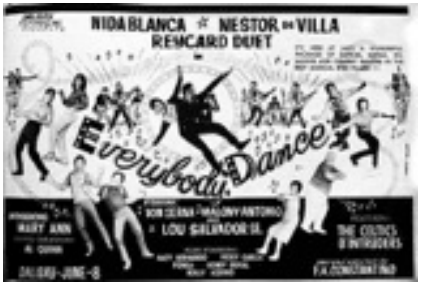

1965

- Swanie is directed by Efren Reyes for Jafere Productions.

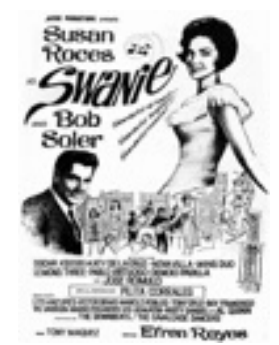

1966

- Let's Do The Freddie is directed by Pablo Santiago for Pablo S. Santiago Productions.

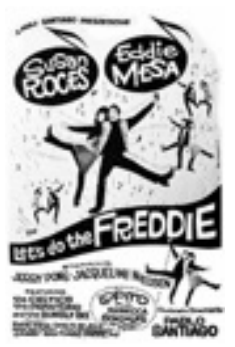

- Shake Baby Shake is directed by Jose Wenceslao and produced by Lea Productions with music by Restie Umali. 


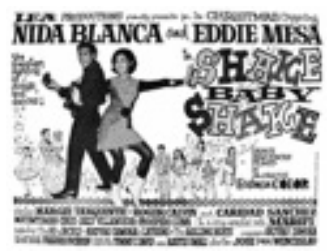

- Manila Hulabaloo is directed by Romy Villaflor and produced by Tagalog Ilang llang Productions with music by Carding Cruz.

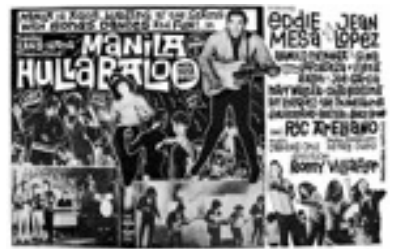

- Saan Ka Man Naroroon is directed by Lauro Pacheco and produced by Larry Santiago with music by Restie Umali.

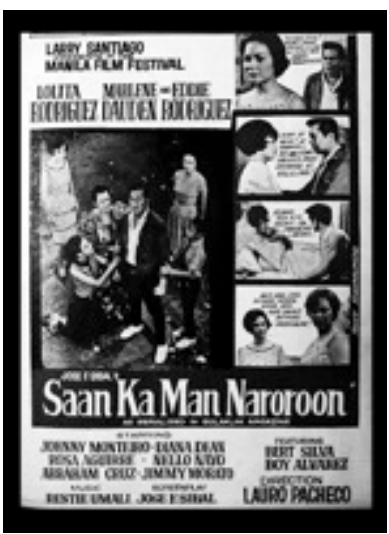

- Sitsiritsit Alibangbang is directed by Ading Fernando and produced by RVQ Productions with music by Restie Umali. 


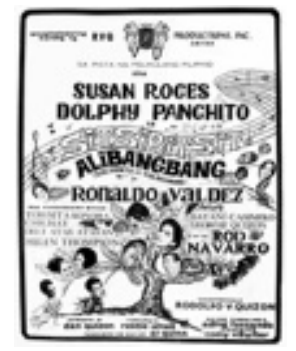

- Dahil Sa Isang Bulaklak is directed by Jose Nepomuceno and produced by Nepomuceno Productions with music by Polding Silos ( $2^{\text {nd }}$ Manila Film Festival winner).

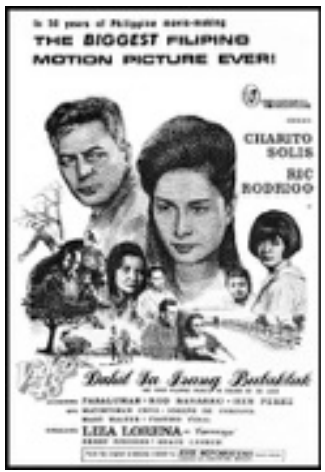

- Ang Langit Sa Lupa is directed by Luis Nepomuceno and produced by Nepomuceno Productions with music by Polding Silos.

soon at net Earivg. A BEAUTIFUt love story
that will remain unparalleled in years to come.

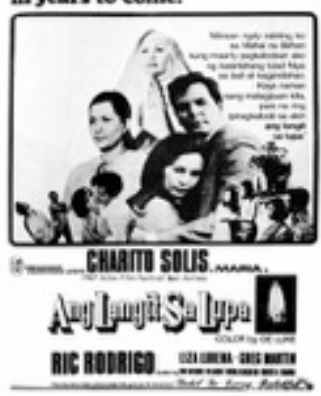




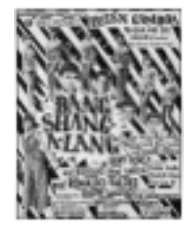

- Bang Shang-a-Lang, starring Helen Gamboa and Jerry Pons, is directed by Consuelo Osorio for RJF Brothers Pictures.

- Stop, Look and Listen is directed by Mitos Villareal and produced by Sampaguita Pictures with music by Doming Valdez.

Release Date: June 15 at the Maxim Theater.

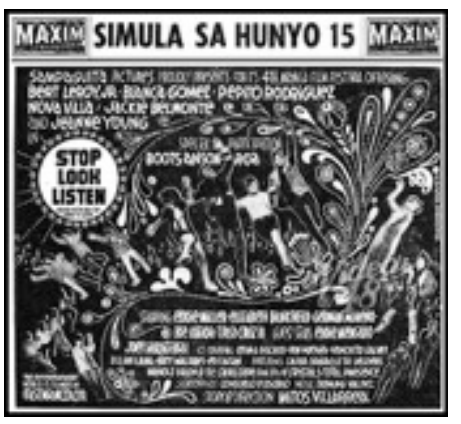

- D' Musical Teenage Idols is directed by Carling Marquez and produced by Tower Productions with music by Romenz.

Release Date: September 23 at the World Theater.

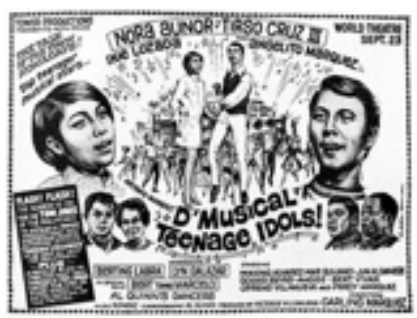

- Obladi Oblada is directed by Jose Wenceslao and produced by Lea Productions with music by D'Amarillo. 


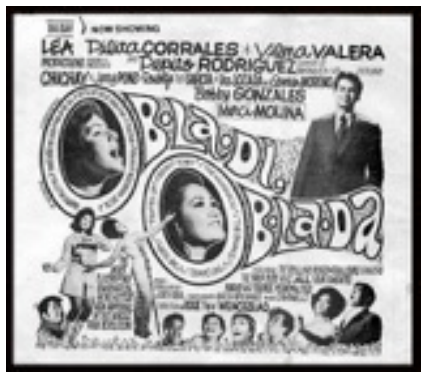

1970

- Happy Hippie Holiday which stars Hilda Koronel, Ed Finlan, and Jay Ilagan is directed by Tony Cayado for Lea Productions.

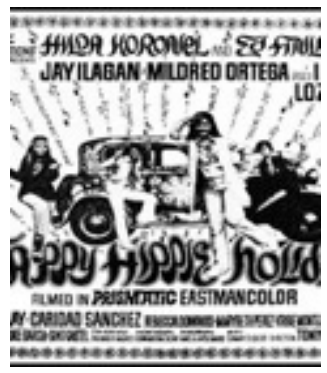

1971

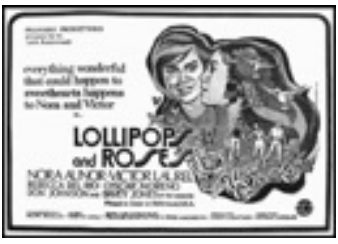

- Lolipops and Roses which stars Nora Aunor and Cocoy Laurel is directed by Artemio Marquez for Premiere Productions.

- Winter Holiday is directed by Jose de Villa and produced by Sampaguita-VP Pictures with music by Danny Holsem. 


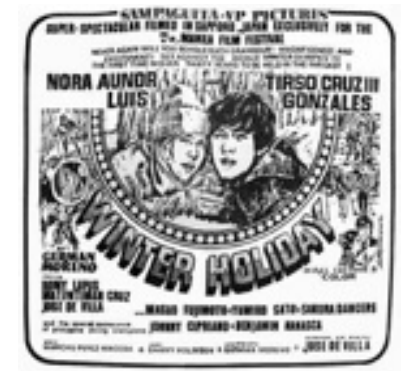

1973

- Hindi Kita Malimot with direction and music by Danny Holsem stars Nora Aunor and Tirso Cruz III. The title song Hindi Kita Malimot is composed by Josefino Cenizal.

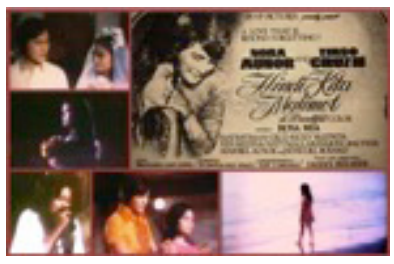

1974

- Happy Days Are Here Again directed by Cirio Santiago is a musical revue and compilation of clips from the movies of LVN Pictures, Sampaguita Pictures, and Premiere Productions.

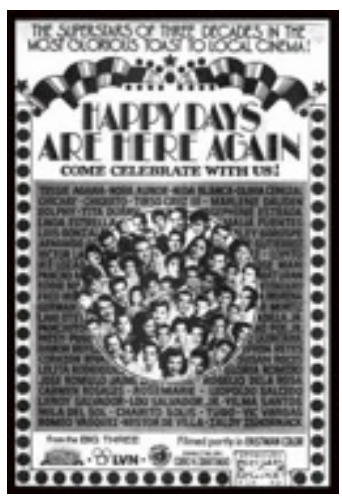


- Annie Batumbakal is directed by Maryo J. delos Reyes.

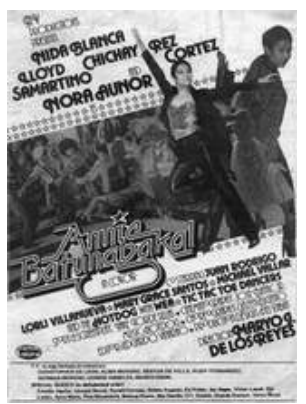

- Oh Margie Oh is directed by Raul Silos and produced by VL Productions with music by D'Amarillo.

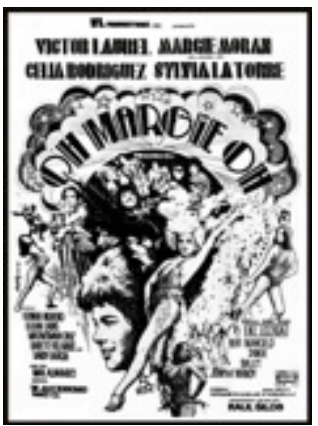

1975

- Araw-Araw Gabi-Gabi is directed by Danilo Cabriera and produced by Lyra Ventures with music by Willy Cruz.

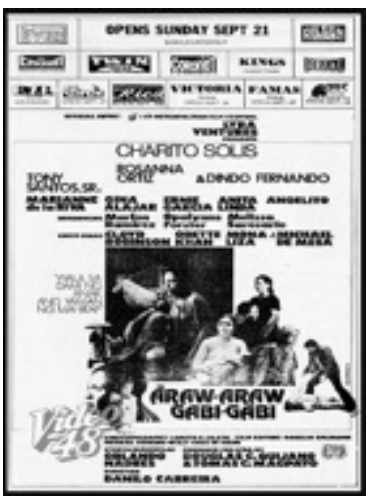


- Diligin Mo Ng Hamog Ang Uhaw Na Lupa is directed by Augusto Buenaventura and produced by JE Productions with music by Ernani Cuenco.

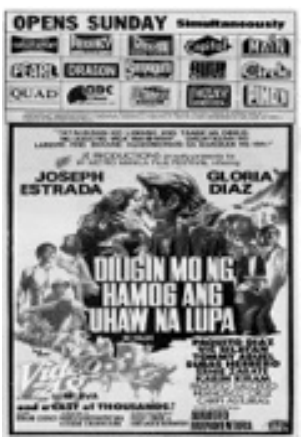

- Bato Sa Buhangin is directed by Pablo Santiago and produced by FPJ Productions with music by Ernani Cuenco.

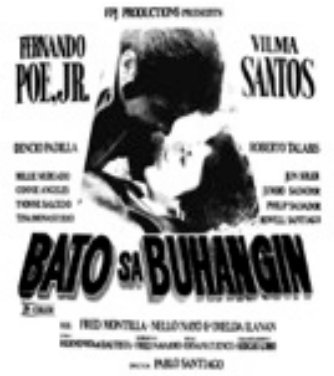

- Disco Baby is directed by Luciano B. Carlos and produced by Regal Films Inc.

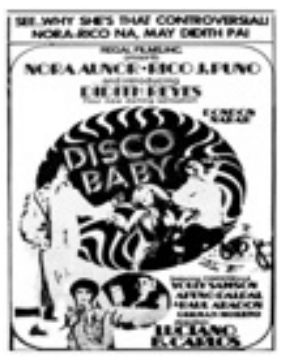


- Bakya Mo Neneng is directed by Augusto Buenaventura and produced by JE Productions with music by Ernani Cuenco.

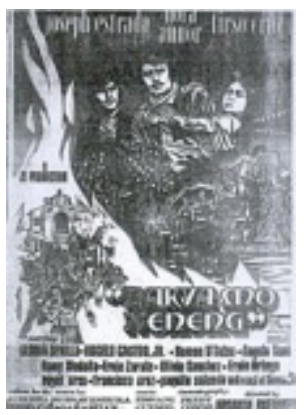

- Pag-ibig Ko'y Awitin Mo is directed by Luis Enriquez and produced by Lea Productions with music by Rudy Arevalo.

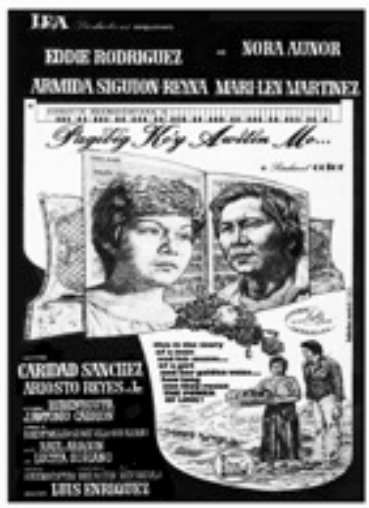

- Masikip Maluwag Paraisong Parisukat is directed by Elwood Perez and produced by Sampaguita Pictures with music by Ryan Cayabyab (its $2^{\text {nd }}$ and $40^{\text {th }}$ Anniversary presentation).

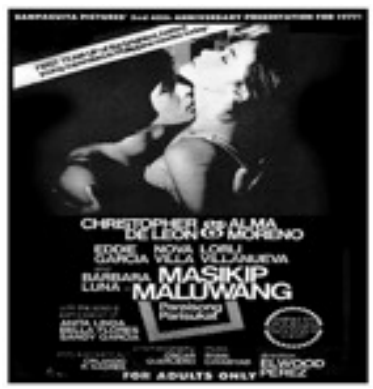


- Panakip Butas is directed by Romy Suzara and produced by Regal Films with music by Ernani Cuenco.

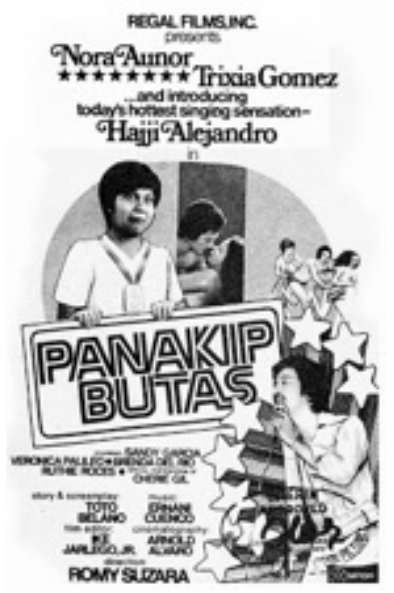

1978

- Pagputing Uwak Pagitim ng Tagak is directed by Celso ad Castillo and produced by V.S. Film Co. Inc. with music by George Canseco.

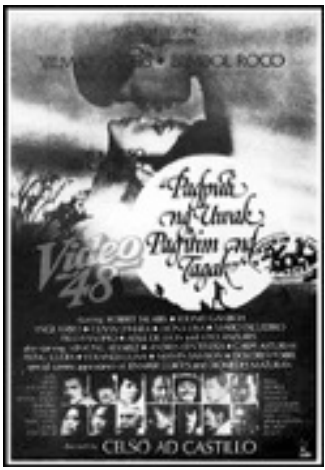

1979

- A "new" type of musical incorporates serious social commentaries.

- Kastilyong Buhangin is directed by Mario 'O Hara and produced by Lotus Films with music by George Canseco. 


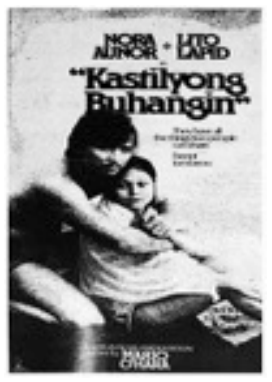

- Langis at Tubig is directed by Danny Zialcita and produced by Sining Silangan with music by George Canseco.
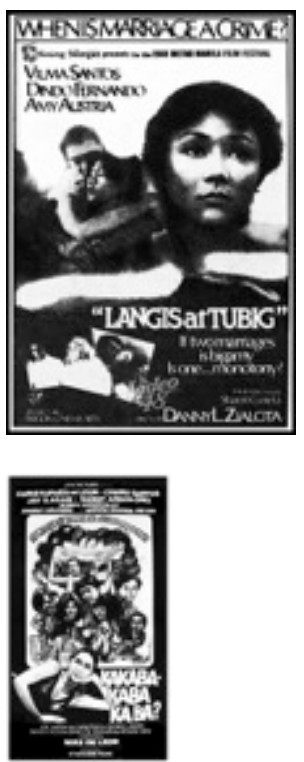

- Kakabakaba Ka Ba is directed by Mike de Leon for Regal Films.

\section{1}

- Pabling is directed by Ishmael Bernal and produced by Regal Films Inc. with music by Vanishing Tribe. 


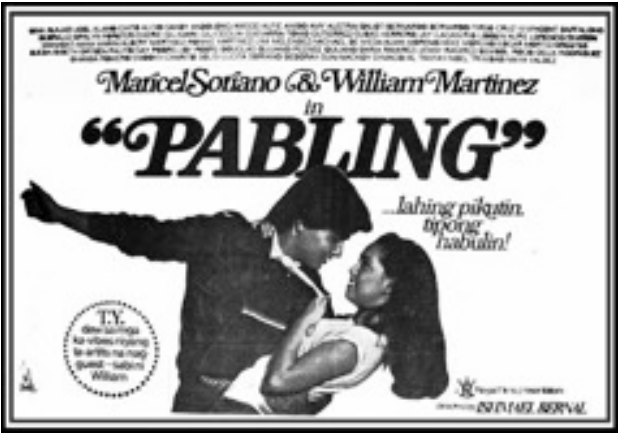

- Dear Heart is directed by Danny Zialcita and produced by Sining Silangan with music by George Canseco.

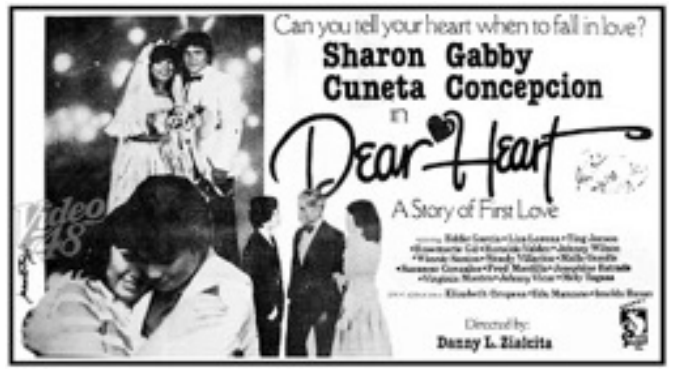

- P.S. I Love You is directed by Eddie Garcia and produced by Viva Films with music by George Canseco.

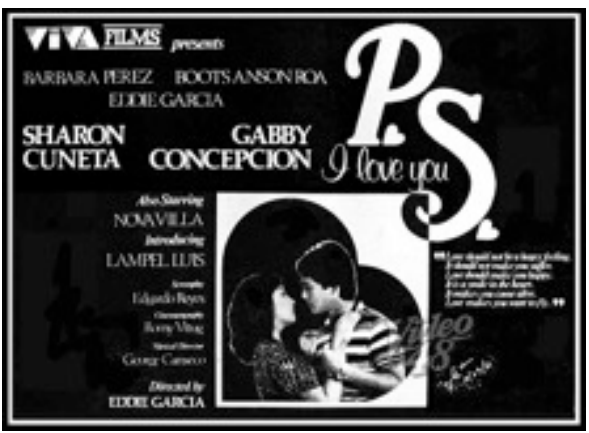

1982

- Hindi Kita Malimot is directed by Ishmael Bernal and produced by Regal Films Inc. with music by Vanishing Tribe. Performances are given by Maricel Soriano and William Martinez. 


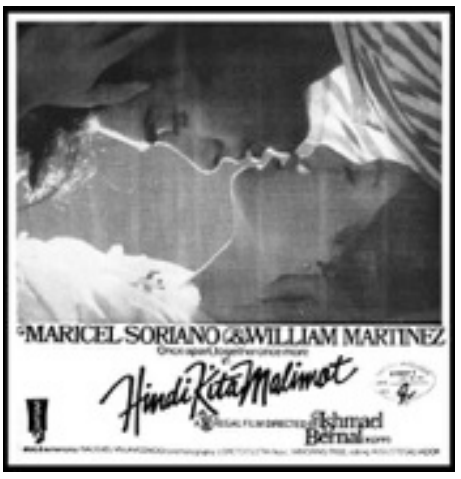

- Sinasamba Kita is directed by Eddie Garcia and produced by Viva Films with music by George Canseco.

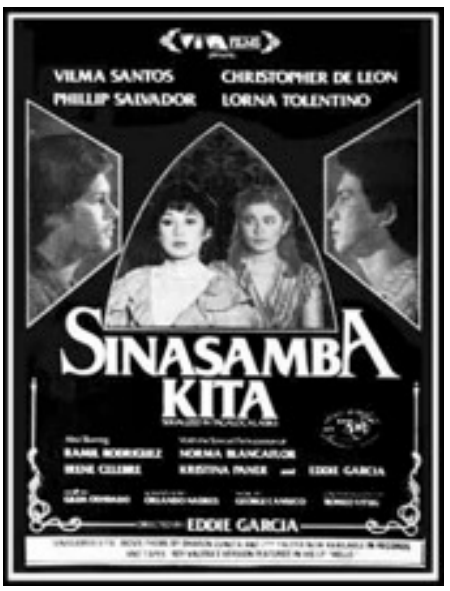

- Gaano Kadalas Ang Minsan is directed by Danny Zialcita and produced by Viva Films with music by George Canseco. 


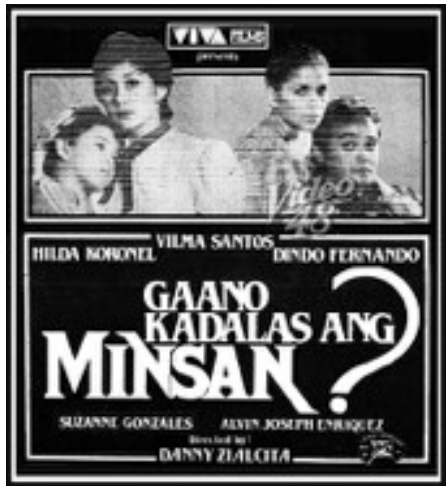

1983

- Saan Darating Ang Umaga is directed by Maryo J. delos Reyes and produced by Viva Films with music by George Canseco.

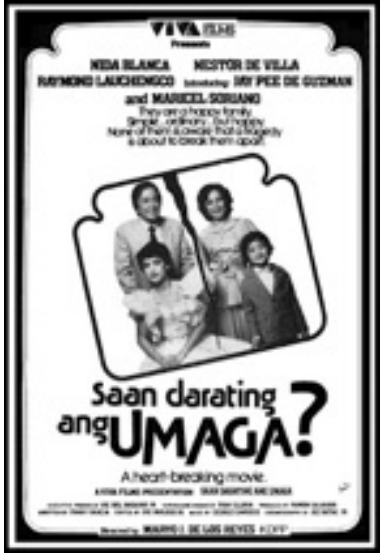

1984

1985

- Bayan Ko: Kapit sa Patalim is directed by Lino Brocka and produced by Vera Belmont with music by Jess Santiago. 


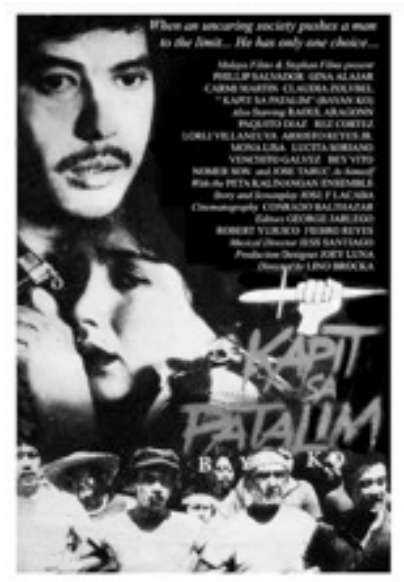

1986

- Sinta Ang Bituing Bagong Gising is directed by Dindo Angeles \& Onofre Pagsanjan with music by Ryan Cayabyab, Quito Colayco, Onofre Pagsanjan, and Bong Penera.

1987

1988

1989

1990

1991

- Maging Sino Ka Man is directed by Eddie Rodriguez and produced by Viva Films with music by Jimmy Fabregas.

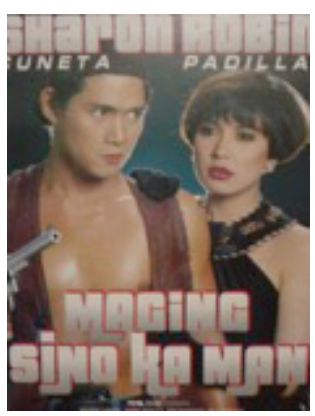


- Narito Ang Puso Ko is directed by Chito Rono and produced by Octoarts Films with music by Jaime Fabregas.

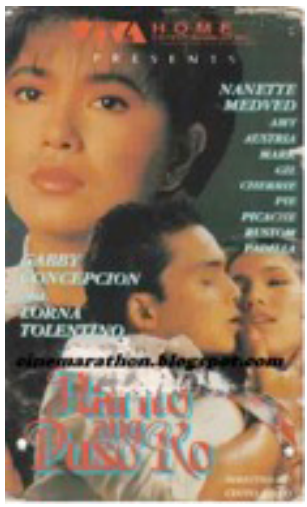

1993

- Dahil Mahal Kita is directed by Laurice Guillen and produced by Octoarts Films with music by Nonong Buencamino.

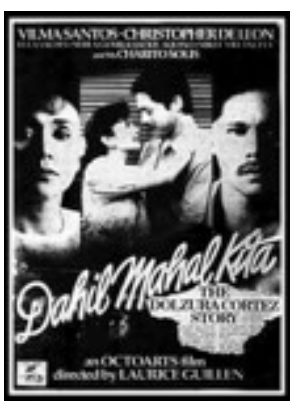

- Kung Ako'y liwan Mo is directed by Marilou Diaz Abaya and produced by Regal Films. 


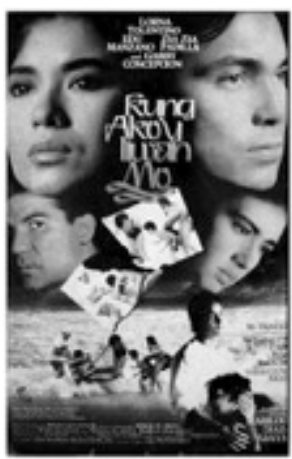

1994

- Ikaw Ang Miss Universe Ng Buhay Ko is directed by Ben Feleo and produced by Vic del Rosario, Jr. with music by Ricky del Rosario.

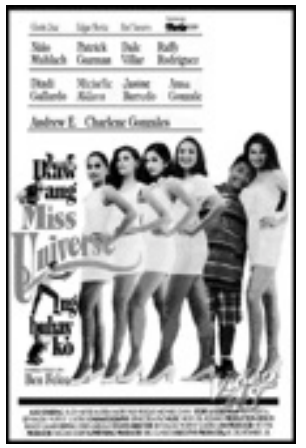

1995

- Muling Umawit Ang Puso is directed by Joel Lamangan and produced by Vic del Rosario, Jr. with music by Venee Saturno. 


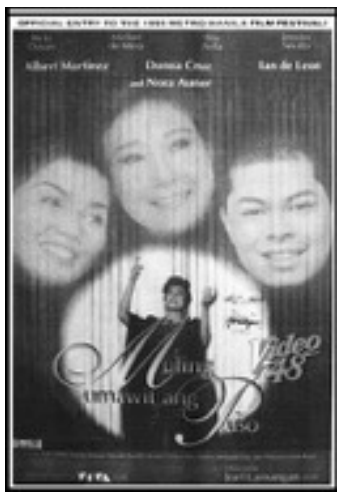

1996

1997

1998

- Muling Ibalik Ang Tais Ng Pag-ibig is directed by Boots Plata and produced by Star Cinema with music by George Canseco.

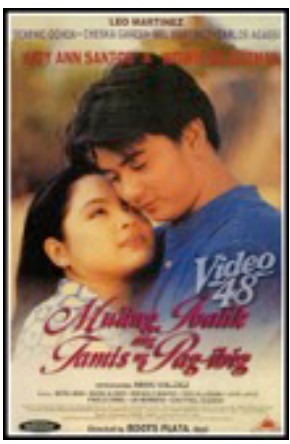

1999

- Dito Sa Puso Ko is directed by Eric Quizon and produced by Viva Films with music by Ardie Lopez. 


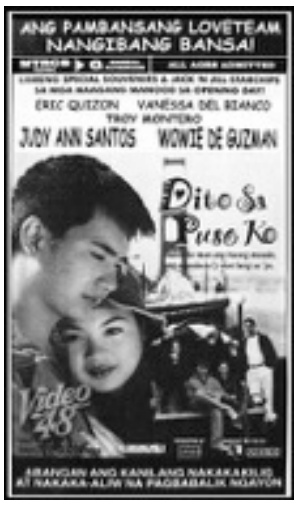

- Mula sa Puso is directed by Wenn Deramas and produced by Star Cinema with music by Jesse Lasaten.

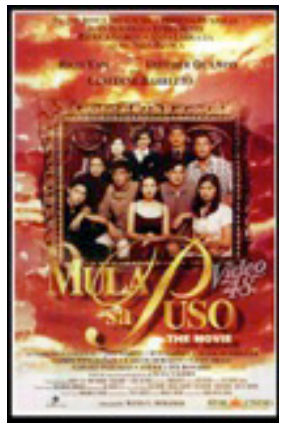

- Tanging Yaman is directed by Laurice Guillen and produced by Star Cinema with music by Nonong Buencamino.

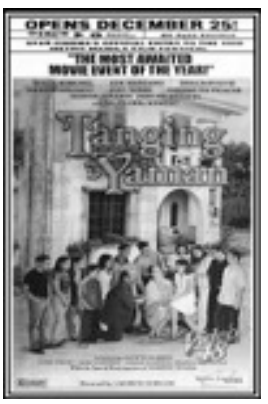


- Cinemalaya Independent Film Festival begun this year.

- Now That I Have You is directed by Laurenti Dyogi and produced by Star Cinema. The song is composed by Trina Belamide.

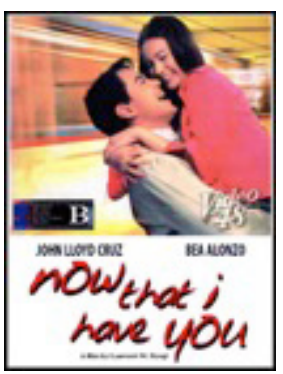

\section{5}

\section{6}

- Close to You is directed by Cathy Garcia-Molina and produced by Star Cinema with music by Jimmy Antiporda and song by Christian Martinez.

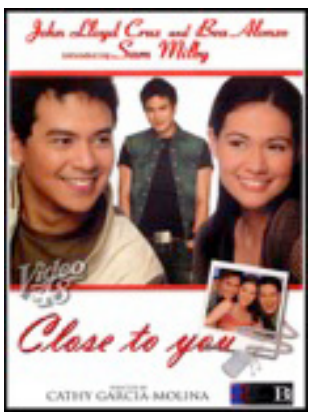


- Emir is directed by Chito Rono for Viva Films.

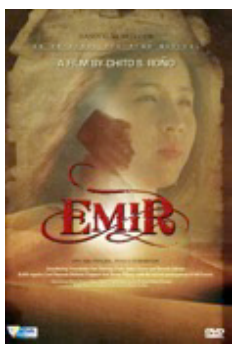

2011

2012

- I Do Bidoo Bidoo: Heto nAPO Sila! is directed by Chris Martinez for Unitel/ TV5 with Eugene Domingo performing.

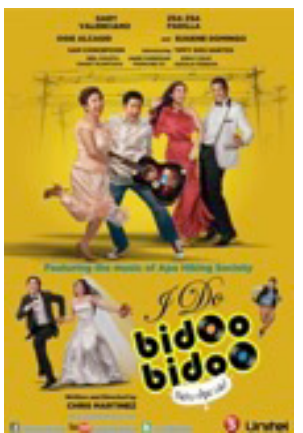


- One More Try is directed by Ruel S. Bayani and produced by Star Cinema with sound design by Jedricke Caballa and song by Cecile Azarcon.

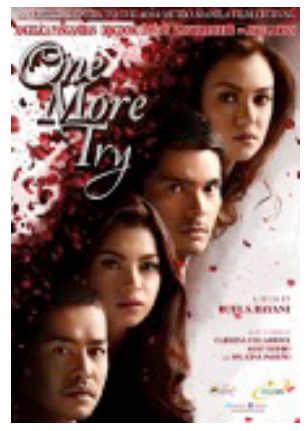

2013

(Electronic copies of posters and flyers are reprinted with permission from Mr. Simon Santos and Video 48.) 


\section{Works Cited}

Adorno, Theodor and Hanns Eisler. Composing for the Films. Continuum International Publishing Group, 2007.

Alejo, Albert E. S.J. Tao po! Tuloy! Isang Landas ng Pag-unawa sa Loob ng Tao. Office of Research and Publications, Ateneo de Manila University, 1990.

Almario, Virgilio. S. “Art and Politics in the Balagtasan." UCLA: Center for Southeast Asian Studies Colloquium, 21 Oct. 2003, https://escholarship.org/ uc/item/23b7f9h6.

Anak Dalita. Directed by Lamberto Avellana, performances by Rosa Rosal, Vic Silayan, and Rosa Aguirre, LVN Pictures Inc., 1956.

“Anak Dalita." IMDb, www.imdb.com/title/tt0372761/. Accessed 6 Oct. 2014.

Angeles, Servando. Bituing Marikit na hango sa operetang "Dakilang Punglo".

Composed by Nicanor Abelardo. Sixta N. Vda de Abelardo, 1926.

Ang Maya. Directed by Jose Nepomuceno, performances by Consuelo Salazar and Fernando Poe, Excelsior Films, 1938.

Ang Tangi Kong Pag-ibig. Directed by Mar S. Torres. Sampaguita Pictures Inc., 1955.

Ang Viuda Alegre. Directed by Enrique Herrera-Davila, performances by Lucita

Goyena, Fernando Poe, Serafin Garcia, X’Otic Films, 1941.

“Ariston Avelino." IMDb, www.imdb.com/name/nm0041653/. Accessed 9 Oct. 2014.

Arriola, Joyce L. "Korido-Komiks Into Film: Sourcing, Adopting, and Recycling the Bernardo Carpio Story." Humanities Diliman, vol. 11, no.1, 2014, pp.1-28.

Asistio, Narciso S. Nasaan Ka Irog. Composed by Nicanor Abelardo. Sixta N. Vda de Abelardo, 1923.

Barwick, Linda. "The Filipino Komedya and the Italian Maggio: Cross-Cultural

Perspectives on Related Genres of Popular Music Theatre." Masks of Time:

Drama and its Contexts. Edited by A.M. Gibbs, Highlands Press, 1994, pp.71-91. Bautista, Arsenio "Boots." "History of Philippine Cinema." National Commission for Culture and the Arts, 14 Apr. 2015, http://www.ncca.gov.ph/about-culture-andarts/articles-on-c-n-a/article.php?i=115\&igm=1. Accessed 9 Oct. 2014.

Bernardo Carpio. Directed by Benjamin Resella, Artemio B. Tecson, performances by Cesar Ramirez, Alicia Vergel, Bella Flores, Sampaguita Pictures, 1951. 
Bituing Marikit. Directed by Carlos Vander Tolosa. Sampaguita Pictures Inc., 1957. Boardwell, David, Janet Steiger, and Kristin Thompson. The Classical Hollywood Cinema: Film Style and Mode of Production to 1960. Routledge, 1985.

Brown, Royal S. Overtones and Undertones: Reading Film Music. U of California P, 1994.

Buenconsejo, Jose. "Parodic Hybridity in Francisco Buencamino, Sr.'s Music for the Film Ibong Adarna.” Asian Studies, 47, 2011, pp. 29-62.

Buenaventura, Cristina Laconico. The Theater in Manila. $2^{\text {nd }}$ ed., De La Salle UP, 1998.

Burt, George. The Art of Film Music. Northeastern UP, 1994.

Carballo, Bibsy M. Filipino Directors Up Close: The Golden Ages of Philippine Cinema 1950-2010. Anvil Publishing Inc., 2010.

Carpio, Rustica C. Hermogenes Ilagan: Father of Tagalog Zarzuela. U of Santo Tomas Publishing House, 2000.

Casebier, Allan. Film and Phenomenology: Toward a Realist Theory of Cinematic Representation. Cambridge UP, 1991.

Chandler, Daniel. Semiotics: The Basics. $2^{\text {nd }}$ ed., Routledge, 2007.

Chattah, Juan Roque. David Shire's The Conversion: A Film Scoring Guide. Rowman \& Littlefield, 2015.

Chattah, Juan Roque. "Semiotics, Pragmatics and Metaphor in Film Music Analysis." Dissertation, Florida State University, 2006.

Collegian Love. Directed by Carlos Vander Tollosa, performances by Naty

Fernandez and Gregorio Fernandez, Araw Movies, 1930.

Coroza, Michael. Personal Interview. 21 Mar. 2015.

Covar, Prospero. “Kaalamang Bayang Dalumat ng Pagkataong Pilipino.” Professional Chair Series, no.95-4. U.P. College of Social Sciences and Philosophy, 1993.

Creston, Paul. "Music and Mass Media.” Music Educators Journal, vol. 56, no.8, 1970, pp. 35, 101-106.

Cruz, Isagani R., editor. A Short History of Theater in the Philippines. Philippine

Educational Theater Association, 1971.

“Dalagang Bukid.” IMDb, www.imdb.com/title/tt0451692/. Accessed 9 Oct. 2014.

De Leon, Felipe M. Jr. "But What Really is the Kundiman." Philippine Daily Inquirer. 2 Dec. 1996, pp. E1-E2.

De Ocampo, Nick. Cine: Spanish Influences on Early Cinema in the Philippines. Anvil Publishing, Inc., 2007. 
---. Film: American Influences on Philippine Cinema. Anvil Publishing Inc., 2011.

---. Personal Interview. 25 June 2014.

Fernandez, Doreen G. "Zarzuela to Sarswela: Indigenization and Transformation."

Philippine Studies, vol. 41, no. 3, 1993, pp. 320-343.

Filipinas Para Los Filipinos.

Flores, Patrick D. "Philippine Cinema and Society." Filipiniana Reader: A Companion

Anthology of Filipiniana Online, edited by Priscilla Pantajo-Legasto, OASIS:

University of the Philippines Open University, 1998, pp. 420-429.

Francia, Luis H. A History of the Philippines: From Indios Bravos to Filipinos.

Overlook Press, 2014.

Fülöp, Rebecca Naomi. "Heroes, Dames, and Damsels in Distress: Constructing

Gender Types in Classical Hollywood Film Music.” Dissertation,

University of Michigan, 2012.

Garcia, Jessie B. A Movie Album Quizbook. Erehwon Books \& Magazine, 2004.

Giliw Ko. Directed by Carlos Vander Tolosa. LVN Pictures, 1939.

Giliw Ko (1939). IMDb, www.imdb.com/title/tt0442245/. Accessed 24 Aug. 2014.

Green, Jessica. "Understanding the Score: Film Music Communicating to and

Influencing the Audience.” Journal of Aesthetic Education, vol. 44, no.4, 2010, pp. 81-94.

Guillermo, Ramon. "Translation as Argument: The Non-Translation of Loob in

Ileto's Pasyon and Revolution." Philippine Studies, vol. 62, no. 1, 2014, pp. 3-28.

Hila, Antonio C. Music in History, History in Music. U of Santo Tomas Publishing

House, 2004.

Ibong Adarna. Directed by Vicente Salumbides. LVN Pictures. Inc. Simon Santos

Collection, 1941.

"Ibong Adarna." IMDb, www.imdb.com/title/tt0787034/. Accessed 6 Oct. 2014.

Ileto, Reynaldo. Pasyon and Revolution: Popular Movements in the Philippines, 1840-

1910. Ateneo de Manila UP, 1979.

Jazz Singer, The. Directed by Alan Crosland, performances by Al Joson, May

McAvoy, Warner Oland, warner Bros., 1927.

“Juan Silos Jr." IMDb, www.imdb.com/name/nm1963389/. Accessed 9 Oct. 2014.

Karlin, Fred and Rayburn Wright. On The Track: A Guide to Contemporary Film Scoring. Routledge, 2004. 
"Kundiman ng Luha." Himig: The Filipino Music Collection of the Filipinas Heritage Library, 2009, http://www.himig.com.ph/songs/54-kundiman-ng-luha. Accessed 6 Oct. 2014.

Kundiman Ng Lahi. Directed by Lamberto V. Avellana. LVN Pictures, 1959.

"Kundiman ng Lahi." IMDb, www.imdb.com/title/tt0357846/. Accessed 6 Oct. 2014.

Kundiman ng Puso. Directed by Tony Cayado, performances by Lolita Rodriguez,

Eddie Arenas, and Tony Marzan, Sampaguita Pictures, 1958.

La Venganza de Don Silvestre. Directed by Jose Nepomuceno, performances by Atang dela Rama and Marceliano Ilagan, Malayan Movies, 1920.

Lapeña-Bonifacio, Amelia. The "Seditious" Tagalog Playwrights: Early American Occupation. Zarzuela Foundation of the Philippines Inc., 1972.

Leinburger, Charles. Ennio Morricone's The Good, The Bad, and The Ugly: A Film Score Guide. Scarecrow Press Inc., 2004.

Lumbera, Bienvenido, Marra P.L. Lanot, Rosalie Matilac, Lena S. Pareja, and Nicanor G. Tiongson, "Sources and Influences." CCP Encyclopedia of Philippine Art: Philippine Film, edited by Nicanor G. Tiongson Cultural Center of the Philippines, 1994, pp. 68-80.

Lumbera, Bienvenido. "Problems in Philippine Film History." Filipiniana Reader: A Companion Anthology of Filipiniana Online, edited by Priscilla Pantajo-Legasto, OASIS: University of the Philippines Open University, 1998, pp.397-405.

Lumbera, Bienvenido. Re-Viewing Filipino Cinema. Anvil Publishing Inc., 2011. Maala-ala Mo Kaya? Directed by Mar. S. Torres, Sampaguita Pictures Inc., 1954. “Maalaala Mo Kaya?” IMDb, www.imdb.com/title/tt0370911/. Accessed 6 Oct. 2014.

Maceda, Teresita Gimenez. "Imaging the Nation as Inang Bayan: Kundiman and Other Songs on the 1896 Revolution." Filipiniana Reader: A Companion Anthology of Filipiniana Online, edited by Priscilla Pantajo-Legasto, OASIS: University of the Philippines Open University, 1998, pp. 346-362.

Madaling Araw. Directed by Carlos Vander Tolosa, performances by Elsa Oria, Ely Ramos and Yolanda Marquez, Sampaguita Pictures, 1938.

Mahiwagang Binibini: Ang Kiri.'Directed by Serafin de los Angeles, performances by Atang Dela Rama, Precioso Palma, and Carmen Rosales, 1939.

Magbalik Ka, Hirang. Directed by Lorenzo P. Tuells, performances by Corazon Noble, Octavio Romero, and Bert LeRoy, Sampaguita Pictures, 1940. 
Metz, Christian. Film Language a Semiotics of the Cinema. The University of Chicago Press, 1974.

Molina, Antonio. “Ang Kundiman ng Himagsikan.” Publications of the Institute of National Language, Vol. IV, No. 22, 1940, pp. 13-30.

Moreno, German. Personal Interview. 3 July 2014.

Morgan, David. Knowing the Score: Film Composers Talk About the Art, Craft, Blood, Sweat, and Tears of Writing for Cinema. Harper Collins Publishers Inc., 2000. Mutya Ng Pasig. Directed by Richard Abelardo. LVN Pictures, 1950.

Mutya ng Pasig. IMDb, www.imdb.com/title/tt0442359/. Accessed 6 Oct. 2014.

Nicolasora, Michelle. "Kundiman: A Musical and Socio-Cultural Exploration on the Development of the Philippine Art Song." Dissertation, University of Memphis, 2014.

Pagdating ng Takip-silim. Directed by Rosa Mia. Sampaguita Pictures Inc., 1956.

Pakiusap. Directed by Octavio Silos. Excelsior Films, 1940.

Pista Sa Nayon. Directed by Manuel Silos. LVN Pictures. Inc., 1948.

"Pista sa Nayon." IMDb, www.imdb.com/title/tt0442413/. Accessed 9 Oct. 2014.

Potenciano, Irma, P.E. Personal Interview. 5 July 2014.

Prendergast, Roy M. Film Music: A Neglected Art. WW Norton \& Company, 1992.

Prinsesa ng Kumintang. Directed by Gerardo de Leon, performances by Juanita

Angeles, Tito Arevalo, and Florentino Ballecer, LVN Pictures, 1940.

Rafael, Vicente L. White Love and Other Events in Philippine History. Duke

University Press, 2000.

Reyes, Manuel A. Notes on Philippine Cinema. De La Salle University Press, 1989.

Reyes, Severino. Ang Maya (las mayas) vals de laz zarzuella "Filipinas para los

Filipinos." Composed by Jose A. Estrella. Jose Oliver Succ., 1905.

Rizal, José, 1861-1896. Noli Me Tangere. Pambansang Suriang Pangkasaysayan, 1990.

Salazar, Zeus. “Ang Pantayong Pananaw Bilang Diskursong Pangkabihasnan.”

Pantayong Pananaw: Ugat at Kabuluhan, Pambungad sa Pag-aaral ng Bagong

Kasaysayan, edited by Atoy Navarro, Mary Jane Rodriguez, and Vicente Villan.

Palimbagan ng Lahi, 2000.

Sa Isang Sulyap Mo Tita. Directed by Armando Garces. Sampaguita Pictures, 1953.

Salumbides, Vicente. Motion Pictures in the Philippines. Manila: Vicente Salumbides, LL.B., 1952. 
Santos, Ramon P. "Musika ng Zarsuela-Sarswela: Isang pag-aral sa Etimolodyi, Katangian at Kahalagahan Sa Isang Uri ng Paghahayag- Damdaming Filipino.” Philippine Humanities Review, vol. 11, no.1-2, 2010, pp. 277-319.

---. Tunugan: Four Essays on Filipino Music. University of the Philippines Press, 2005. Santos, Simon. "More on Pre-war Tagalog Movies: Giliw Ko (1939): LVN Pictures Debut Movie.” Video48, 26 Feb. 2011, www.video48.blogspot.com/2011/02/ more-on-pre-war-tagalog-movies-giliw-ko.html. Accessed 14 Oct. 2014.

Sarung Banggi. Directed by Susana C. De Guzman. LVN Pictures, 1947.

"Sarung Banggi." IMDb, www.imdb.com/title/tt0475713/. Accessed 6 Oct. 2014.

Sa Tokyo Ikinasal. Directed by Manuel Silos. LVN Pictures, 1948.

"Sa Tokyo Ikinasal." IMDb, www.imdb.com/title/tt0442461/. Accessed 9 Oct. 2014.

“Singin' In the Rain.” IMDb, www.imdb.com/title/tt0045152/. Accessed 9 Oct. 2014.

Smith, Anthony D. National Identity. Penguin Books, 1991.

Stam, Robert. Film Theory: An Introduction. Blackwell Publishers Inc., 2000.

Stone, Ruth S. Theory for Ethnomusicology. Pearson Prentice Hall, 2008.

“The Jazz Singer.” IMDb, www.imdb.com/title/tt0018037/. Accessed 2 Oct. 2014.

"The Silos Family: Juan Silos Jr." The Silos Family Website. www.silosfamily.com/

juanSilosJr.html. Accessed 9 Oct. 2014.

Tiongson, Nicanor G. The Cinema of Manuel Conde. University of Santo Tomas Publishing House, 2008.

Tiongson, Nicanor G. "A Short History of the Philippine Sarswela (1879-2009).”

Philippine Humanities Review, vol. 11, no.1-2, 2010, pp. 149-186.

---, editor. The Urian Anthology, 1980-1989: Film Essays and Reviews by the Manunuro ng Pelikulang Pilipino with a filmography of Philippine Movies, 1980-1989. Antonio P. Tuviera, 2001.

Tolentino, Aurelio. Kahapon, Ngayon, at Bukas. Limbagang Tolentino, 1913.

Tolentino, Rolando B. National/Transnational Subject Formation and Media in and on the Philippines. Ateneo de Manila University Press, 2001.

Torralba, George. Personal Interview. 21 June 2014.

Tunay Na Ina. Directed by Octavio Silos. Excelsior Films Inc., 1939.

“Tunay na Ina.” IMDb, www.imdb.com/title/tt0415333/. Accessed 9 Oct. 2014.

Walang Sugat. Directed by Enrique Herrera-Davila, performances by Leopoldo

Salcedo and Rosa del Rosario, Filippine Productions, 1939.

Weirzbicki, James Eugene. Film Music: A History. Routledge, 2009. 
Yeatter, Bryan L. Cinema of the Philippines: A History and Filmography 1897-2005.

McFarland \& Company, Inc., Publishers, 2007.

“Zamboanga.” IMDb, www.imdb.com/title/tt0167505/. Accessed 17 Sept. 2014.

\section{Works Consulted}

Covar, Prospero. “Kaalamang Bayang Dalumat ng Pagkataong Pilipino” in Larangan: Seminal Essays on Philippine Culture. Sampaguita Press, pp. 9-16.

Salumbides, Vicente. Motion Pictures in the Philippines. Vicente Salumbides, LL.B., 1952.

Santos, Ramon P. Tunugan Four Essays on Filipino Music. University of the Philippines Press, 2005. 


\section{Author's Bionote}

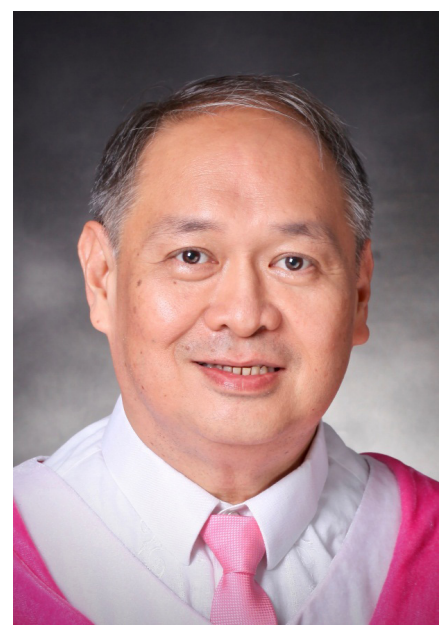

ANTONIO PATERNO AFRICA, PhD - The author studied at San Beda College, Mendiola for his basic education. Upon finishing his Bachelor of Music, major in Composition at the University of Santo Tomas, he returned to his alma mater to teach Music and Humanities in the High School Department from 1986 to 1997. He was also the Conductor and Musical Director of the San Beda High School Glee Club from 1986 until 2006. He started teaching in the college level in 1993 as a part-time Instructor at the UST Conservatory of Music where he is now teaching as a full-time Associate Professor. Africa was Conservatory Secretary from 2004 up to 2009 and was Assistant Dean from 2010 to 2013. He teaches Music Theory, Composition, and Music Technology. He earned two Master of Arts degrees in 2009 for his Master of Music, major in Composition at the UST Graduate School and in 2011 for his Master in Music, major in Ethnomusicology at the Philippine Women's University School of Music. He then proceeded to take his doctoral studies in the same university where, in 2015, he earned the degree of Doctor of Philosophy in Music, major in Ethnomusicology. Currently, he is member of the Commission on Higher Education (CHEd) Technical Committee for Music and the current Dean of the UST Conservatory of Music. Africa is an active composer, arranger, events and culture person, and film musician. 